Portland State University

PDXScholar

Summer 10-8-2019

\title{
The Impact of Integrating Traditional Ecological Knowledge in Summer Camps on Middle School Students' Understanding of the Nature of Science
}

Sapoóq'is Wiîit'es Ciarra Solina Greene Portland State University

Follow this and additional works at: https://pdxscholar.library.pdx.edu/open_access_etds

Part of the Science and Mathematics Education Commons Let us know how access to this document benefits you.

\section{Recommended Citation}

Greene, Sapoóq'is Wíiti'es Ciarra Solina, "The Impact of Integrating Traditional Ecological Knowledge in Summer Camps on Middle School Students' Understanding of the Nature of Science" (2019).

Dissertations and Theses. Paper 5277.

https://doi.org/10.15760/etd.7150

This Thesis is brought to you for free and open access. It has been accepted for inclusion in Dissertations and Theses by an authorized administrator of PDXScholar. Please contact us if we can make this document more accessible: pdxscholar@pdx.edu. 
The Impact of Integrating Traditional Ecological Knowledge in Summer Camps on Middle School Students' Understanding of the Nature of Science

\author{
by \\ Sapóoq'is Wiíit'es Ciarra Solina Greene
}

A thesis submitted in partial fulfillment of the requirements for the degree of

Master of Science

in

Science Teaching

Thesis Committee:

Stephanie Wagner

William Becker

Gabe Sheoships

Judy Bluehorse Skelton

Portland State University

2019 


\begin{abstract}
The Nature of Science (NOS) and traditional ecological knowledge (TEK) have commonalities in the knowledge bases: they are both ways of explaining the natural world; founded on a set of practices and the historical accumulation of knowledge; and part of the education is learning practices and developing knowledge of the concepts that are foundational to the disciplines. Throughout the United States, schools are attempting to strengthen students' understanding of NOS through various approaches, although few have adopted the integration of TEK into curriculum. This research assesses two summer camps for middle school students that are science focused, one with TEK integration and one with minimal TEK integration. Pre- and post- surveys and student work samples were analyzed to determine the impact of TEK integration on students' understanding of some of the NOS concepts. A significant increase was observed in the camp that integrated TEK, while no change was observed in students' understanding of NOS in the camp that had minimal TEK integration.
\end{abstract}




\section{Dedication}

Resilience. Patience. Integrity. Respect. These values are the foundation upon which I was raised by generations of my Alford, Greene, and Groseclose families. With their love, dedication, support, and (like all families) dysfunction, I have learned forgiveness, sacrifice, compassion, and strength. From the garden of my Granny (Helen), to the sweathouse with my Grandma Geneva, my learning experiences from my family have taught me more than any institutions ever could, and for that I am forever grateful. To every educator I have had along my path from headstart to graduate school, to the youth I teach and the elders I listen to, their contributions to my journey warrants my deepest gratitude. My friends, peers, mentors, and yes, even enemies, have taught me infinite lessons about life; being with the land, water, and relatives has kept me grounded when I needed it most. The experiences I have been able to have around the world have given me the opportunity to represent those who have come before me and those that will come after - a legacy that rests upon my shoulders that I honor. This degree is dedicated to my parents, siblings, loving partner and two boys, Luna, my nieces and nephews, friends, the AISES Council of Elders, and the many people who have prayed for and guided me along this path. WE DID IT! 


\section{Acknowledgements}

This research was supported in part by the Graduate Research Fellowship Program of the National Science Foundation under NSF 15-597. Any Opinions, findings and conclusions or recommendations expressed in this material are those of the author(s) and do not necessarily reflect those of the National Science Foundation.

This research took place on the indigenous homelands of the Atfalati, Cayuse, Clatskanie, Kalapuya, Nimiipuu (Nez Perce), Northern Paiute, Palouse, Tenino, Umatilla, Walla Walla, Wasco, Wishram and Yakama people and recognize that the institution which provide resources to complete the study has does not adequately acknowledge the history of these people in its entirety and their past and present contributions to society. 
Table of Contents

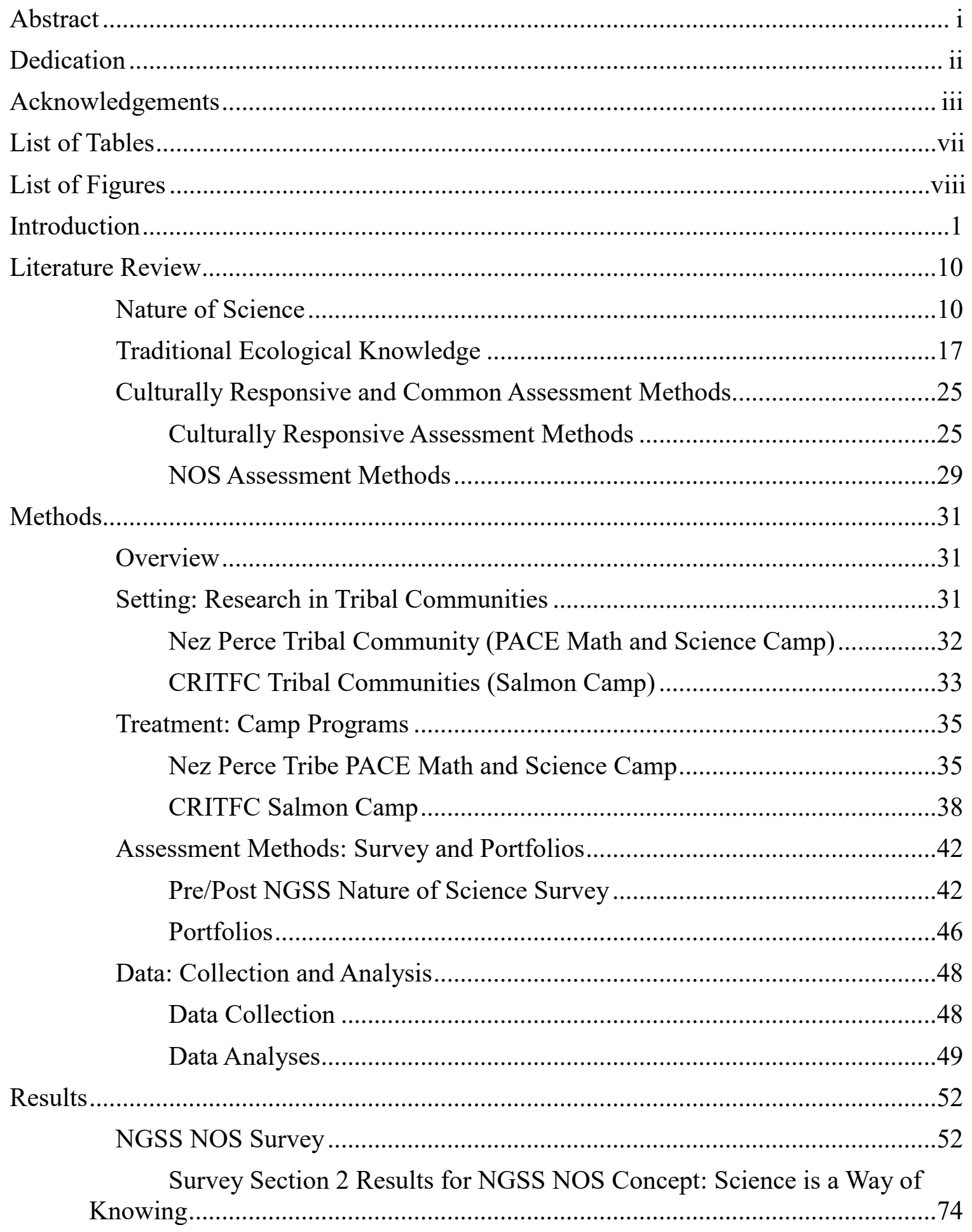


Survey Section 2 Results for NGSS NOS Concept: Scientific Knowledge Assumes an Order and Consistency in Natural Systems ....................................75

Survey Section 2 Results for NGSS NOS Concept: Science is a Human Endeavor

Survey Section 2 Results for NGSS NOS Concept: Science Addresses Questions About the Natural and Material World.... .78 Knowing

Survey Section 3 Results for NGSS NOS Concept: Science is a Way of

Survey Section 3 Results for NGSS NOS Concept: Scientific Knowledge Assumes an Order and Consistency in Natural Systems

Survey Section 3 Results for NGSS NOS Concept: Science is a Human

Explicit NOS Instruction in Camp Activities and Portfolios ...........................97

PACE Instruction and Portfolios........................................................98

Salmon Camp Instruction and Portfolios .............................................107

Comparing PACE and Salmon Camp Instruction and Portfolio Scores .. 114

Comparing Survey Scores and Portfolio Ratings ..................................115

Discussion 116

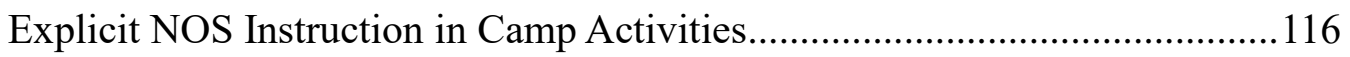

Next Generation Science Standards Nature of Science Concepts ...................117

NGSS NOS Concept: Science is a Way of Knowing............................118

NGSS NOS Concept: Scientific Knowledge Assumes an Order and Consistency in Natural Systems 120

NGSS NOS Concept: Science is a Human Endeavor 122

NGSS NOS Concept: Science Addresses Questions About the Natural and Material World . .124

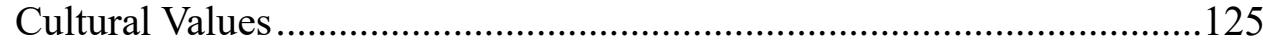

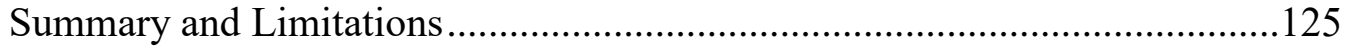

References 128

Appendices. 133

Appendix A NGSS Nature of Science Concepts..............................................133

Appendix B PACE Daily Workshee ............................................................135

Appendix C Research Permit for the Nez Perce Tribe .......................................136

Appendix D IRB Approval from Portland State University ................................137

Appendix E Research Agreement with CRITFC ..............................................138

Appendix F Schedule for PACE Camp ...........................................................139 
Appendix G Schedule for Salmon Camp........................................................143

Appendix H Camp Introduction...................................................................146 
List of Tables

Table 1 Comparing the NGSS NOS concepts (NGSS Lead States, 2013) and Stephens' (2001) TEK/Science Common Ground.

Table 2 Comparison of Version 1 and Version 2 explicit teaching methods of the Nature of Science (Duschl \& Grandy, 2013)....

Table 3 The cosmopolitan domains of traditional ecological knowledge (Hamlin, 2013) 24

Table 4 The Promising assessment strategies (Stephens, 2001, p. 35) .............................27

Table 5 Information for the four CRITFC tribes on population, land base, and educational

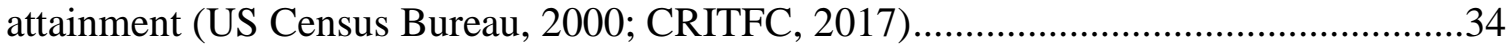

Table 6 Summary of PACE camp activities related to STEM and/or TEK. .....................37

Table 7 Summary of Salmon Camp activities relating to STEM and/or TEK. .................40

Table 8 The modified NGSS NOS Middle School Learning Expectations and the

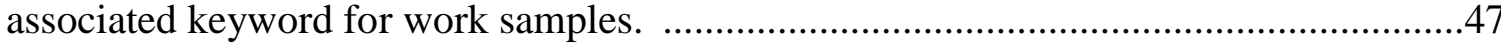

Table 9 The scoring rubric for camp participant portfolios. ............................................51

Table 10 Summary table of changes in Salmon Camp responses for each survey statement.

Table 11 Summary table of changes in Salmon Camp responses for NGSS NOS concepts, compiled from survey statements.

Table 12 Summary table of changes in camp responses to Section 3 survey statements. .91 Table 13 Summary table of changes in camp responses for NGSS NOS concepts, compiled from survey statements.

Table 14 Summary table of portfolio entries for each camp

Table 15 Evaluations of PACE camp activities and teaching methods for NOS explicit instruction.

Table 16 Evaluation of Salmon Camp activities and teaching methods for NOS explicit

instruction. 
List of Figures

Figure 1 Stephens' (2001) Common Ground Model.

Figure 2 Guidelines for culturally-responsive assessment for Native Students (Estrin \&

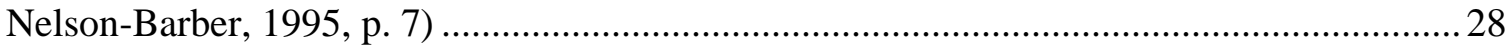

Figure 3 Part I of the survey administered pre and post for both camps .........................45

Figure 4 Part II of the survey administered pre and post for both camps ........................46

Figure 5 TEK-related engagements as declared by camp participants .............................53

Figure 6 Overall pre/post survey responses for each camp. .........................................54

Figure 7 The change in survey responses for each statement for both PACE and Salmon

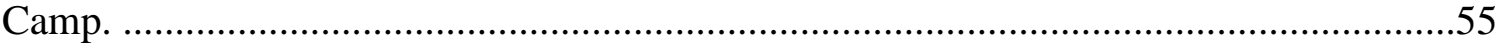

Figure 8 The overall change in survey scores displayed by negative change, no change, and increases of $1-5$ points, $6-10$ points, and more than 10 points. ................................56

Figure 9 Result details for survey statement "science is built upon years of

knowledge."

Figure 10 Result details for survey statement "Science is a solitary pursuit (done

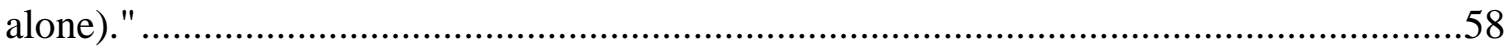

Figure 11 Result details for survey statement "Citizens use science every day."..............59

Figure 12 Result details for survey statement "Observations by citizens do not contribute

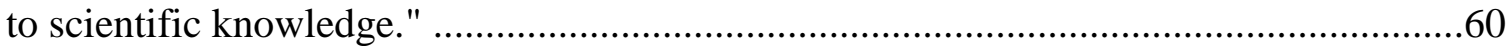

Figure 13 Result details for survey statement "Science can study things and events that happened in the past, even if no one was there to observe it."

Figure 14 Result details for survey statement "Science is based on observation of natural

patterns."

Figure 15 Result details for survey statement "We accept an idea as scientific knowledge only if it doesn't have any errors."

Figure 16 Result details for survey statement "Science data can be interpreted in new

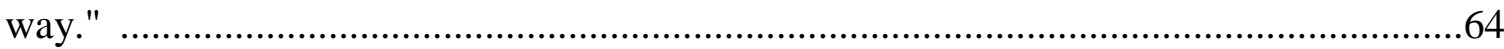

Figure 17 Result details for survey statement "Anyone can be a scientist." ...................65

Figure 18 Result details for survey statement "People from all over the world contribute to science knowledge."

Figure 19 Result details for survey statement "Scientists rarely use creativity." ............67 Figure 20 Result details for survey statement "Disagreement between scientists is one of

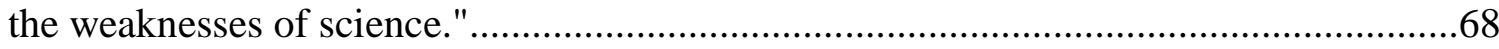

Figure 21 Result details for survey statement "Advances in technology influence the progress of science."

Figure 22 Result details for survey statement "Science is limited by human capacity and technology."

Figure 23 Result details for survey statement "Scientific concepts and discoveries can cause new problems for people."

Figure 24 Result details for survey statement "Scientific knowledge is not responsible for society's decisions." 
Figure 25 Result details for NGSS NOS concept "Science is a way of knowing."

Figure 26 Result details for NGSS NOS concept "Scientific knowledge assumes an order

and consistency in natural systems." .76

Figure 27 Result details for NGSS NOS concept "Science is a human endeavor." ........77 Figure 28 Result details for NGSS NOS concept "Science addresses questions about the

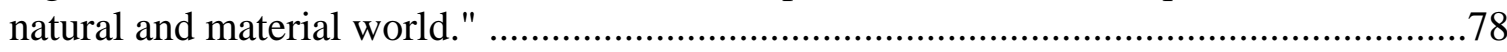
Figure 29 Result details for survey statement "Knowledge is cumulative (continually build upon from prior knowledge

Figure 30 Results details for survey statement "Many people, from many generations and nations, have contributed to our knowledge.".... .82

Figure 31 Results details for survey statement "Different source of knowledge can be used together to benefit one another."

Figure 32 Results details for survey statement "Patterns in nature can be observed and measured.".

Figure 33 Results details for survey statement: Inconsistencies or changes are considered and evaluated."

Figure 34 Result details for survey statement "Men, women and people from different backgrounds engage in building knowledge."

Figure 35 Result details for survey statement "Knowledge is based on observation of natural patterns."

Figure 36 Result details for survey statement "Values like persistence, precision, reasoning, logic, imagination, and creativity are important."

Figure 37 Result details for survey statement "Values like harmony, respect, resiliency, interdependence, and reciprocity (giving mutually) are important." ..............................90 Figure 38 Result details for NGSS NOS concept "Science is a way of knowing." ..........93 Figure 39 Result details for NGSS NOS concept "Scientific knowledge assumes an order and consistency in natural systems."

Figure 40 Result details for NGSS NOS concept "Science is a human endeavor." ..........96

Figure 41 PACE Day 2 keywords and score for portfolio entries. ...............................100

Figure 42 PACE Day 3 keywords and score for portfolio entries. .................................101

Figure 43 PACE Day 4 keywords and score for portfolio entries. ...............................102

Figure 44 PACE Day 5 keywords and score for portfolio entries................................103

Figure 45 PACE Day 6 keywords and score for portfolio entries. ................................104

Figure 46 PACE Day 7 keywords and score for portfolio entries .................................105

Figure 47 PACE Day 8 keywords and score for portfolio entries ..................................106

Figure 48 Salmon Camp Day 2 keywords and score for portfolio entries......................109

Figure 49 Salmon Camp Day 3 keywords and score for portfolio entries......................110

Figure 50 Salmon Camp Day 4 keywords and score for portfolio entries......................112

Figure 51 Salmon Camp Day 5 keywords and score for portfolio entries......................113

Figure 52 Result details of camp portfolio scores by NGSS NOS concept....................114

Figure 53 Change in survey scores and portfolio ratings for PACE and Salmon Camp compared. 
Introduction

What is science? Some educators cannot answer this question succinctly, yet we have expected generations of students to excel in this area of study. If we cannot answer the initial question (what is science?), how are we to raise a science literate and globally competitive society in the fields of science, technology, engineering, and math (STEM)? Frenkel and $\mathrm{Wu}(2013)$ note that the World Economic Forum ranked the U.S. $48^{\text {th }}$ in quality of math and science education out of 139 countries, and research by the Programme for International Student Assessment (PISA) ranked the United States $24^{\text {th }}$ in science when surveying 15-year old students in 71 countries (DeSilver, 2017). With an education system that is lacking, there are unfavorable implications for the progress of our nation, technologically and economically. A 2010 National Academies report "warned that America's ability to compete effectively with other nations is fading" (Frenkel and $\mathrm{Wu}, 2013$, p. 1). In a society seeking global competitiveness, it has been argued for a greater understanding of science by citizens since the 1940's. (Conant, 1947). We, as educators, can and should prepare our next generation with the skills to critically think and address the complex issues of today's world.

The Next Generation Science Standards (NGSS) are the most recent set of science standards and were developed collaboratively by twenty-six state education departments, aiming to improve student achievement (NGSS Lead States, 2013). With only a few years of implementation, curriculum aligned with NGSS has shown promise in improving students' understanding of scientific practices and crosscutting concepts (Yoon et. al., 2015). To address the initial question, “what is science?”, NGSS includes eight Nature of 
Science understandings (i.e. science is a way of knowing) which are closely associated to the NGSS practices and crosscutting concepts (Appendix H provides a full description of the NGSS Nature of Science concepts) (NGSS Lead States, 2013). The Nature of Science (NOS) acknowledges that science is a way of explaining the natural world; science is both a set of practices and the historical accumulation of knowledge; and part of science education is learning STEM practices and developing knowledge of the concepts that are foundational to science disciplines. NOS is different than learning science content, facts, etc. which is widely the perception of what science encompasses (Osborne, 2006). Fifty states and other international education systems have incorporated NOS into science curricula (McComas, 2009; Tytler, 2007; Schwartz and Lederman, 2008). Within NGSS, students are expected to "develop an understanding of the enterprise of science as a whole — the wondering, investigating, questioning, data collecting and analyzing” (NGSS Lead States, 2013, p. 1).

To teach NOS, academic scholars suggest explicit instruction of the concepts for learner understanding to improve (Abell et al., 2001; Akerson et al., 2000; Kang et al., 2004; Khishfe and Abd-El-Khalick, 2002; Lederman and Lederman, 2004; Moss, 2001). NGSS recommends "students have instruction that emphasizes why explanations are based on evidence, that the phenomena they observe are consistent with the way the entire universe continues to operate, and that we can use multiple ways to investigate these phenomena... [and students have] the opportunity to stand back and reflect on how the practices contribute to the accumulation of scientific knowledge" (NGSS Lead States, 2013, Appendix H, p. 7). Although research regarding NOS emphasizes explicit 
instruction of NOS concepts, Duschl and Grandy (2012) identify two versions of explicit instruction: "Version 1 advocates that teachers explicitly link the consensus statements to features of science lessons and activities. Version 2 advocates students engage in domainspecific scientific practices during weeks or months long curriculum units that focus the learners' attention on the model building and refining enactments found in measuring, observing, arguing from evidence and explaining that are part of the growth of scientific knowledge" (p. 2113). Although Duschl and Grandy (2012) recommend Version 2 explicit instruction for NOS, research efforts have been concentrated primarily on Version 1 explicit instruction - the encouraged instruction method for NGSS NOS concepts (Lederman et al. (2002); McComas and Olson (1998); NGSS Lead States, 2013)).

Duschl and Grandy (2012) argue that "Version 2 [explicit NOS instruction] is to be preferred over Version 1 because it develops the critical epistemic cognitive and social practices that scientists and science learners use when (1) developing and evaluating scientific evidence, explanations and knowledge and (2) critiquing and communicating scientific ideas and information; thereby promoting science literacy" (p. 2109). Although the research on explicit instruction of NOS is advancing, there is a disconnect between STEM education research and classroom practices (Rosicka, 2016). Teachers wanting to convey NOS principles while they teach subject matter have little guidance (MacDonald, 1996), and are left trying to piece the puzzle of science content, practices, and concepts together. 


\section{This research investigates the impact of Version 2 explicit instruction on middle school students' understanding of NOS concepts.}

The long-standing knowledge bases developed by indigenous peoples exhibit qualities favorable for teaching NOS crosscutting concepts through Version 2 explicit instruction. For the last twenty years, indigenous traditional ecological knowledge (TEK) has been recognized by international scholars as having equal status with scientific knowledge (United Nations Environment Programme, 1998) and has been termed the "intellectual twin to science" (Deloria, 1995). However, TEK is scarcely incorporated into the academic setting (formal or informal). Traditional ecological knowledge is defined as:

"a body of knowledge and beliefs transmitted through oral tradition and first-hand observation. It includes a system of classification, a set of empirical observations about the local environment, and a system of self-management that governs resource use. Ecological aspects are closely tied to social and spiritual aspects of the knowledge system. The quantity and quality of TEK varies among community members, depending upon gender, age, social status, intellectual capability and profession (hunter, spiritual leader, healer, etc.). With its roots firmly in the past, TEK is both cumulative and dynamic, building upon the experience of earlier generations and adapting to the new technological and socioeconomic changes of the present" (Dene Cultural Institute 1995 in English translation, quoted in Stevenson 1996: 281). 
Traditional ecological knowledge and Western Science have distinctive defining characteristics (e.g. qualitative oral record (TEK) and quantitative written record (Western science)), and a "Common Ground" of comparable foundations (Stephens, 2001).

Figure 1 Stephens' (2001) Common Ground Model.

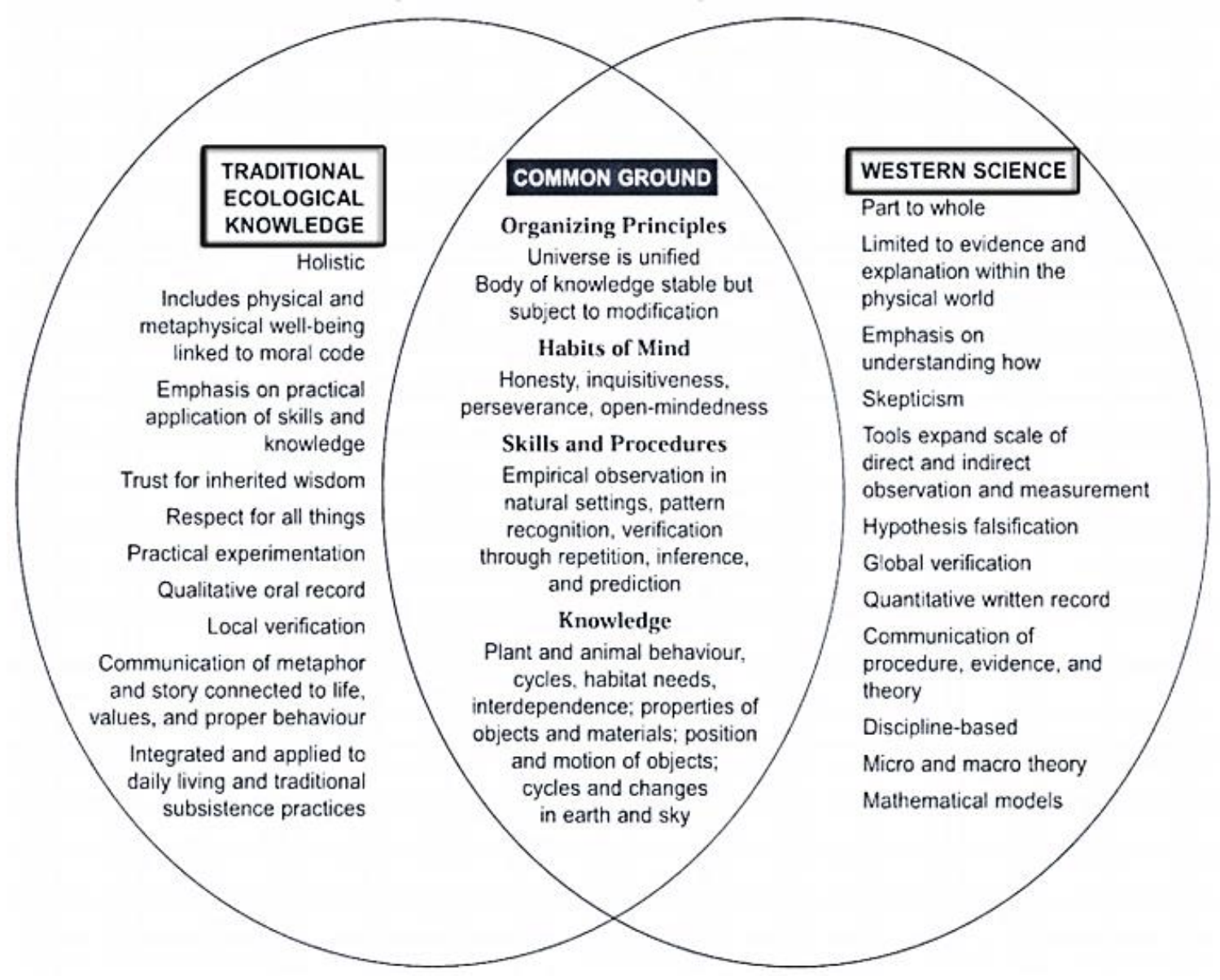

The TEK/Science Common Ground are shared characteristics and values of the

two knowledge bases: the organizing principles, habits of mind, skills and procedures, and knowledge system. A comparison of the TEK/Science Common Ground foundations and the NGSS NOS principles closely associated to the NGSS crosscutting concepts, reveal undeniable parallels (table 1). For example, patterns in nature are at the 
foundation of both knowledge bases, as is being honest and open-minded. Although

some consideration of NOS concepts and TEK have been explored (Bang \& Medin, 2010; Murphy et al., 2010), identifying the association between specific NGSS NOS

Middle School Learning Expectations and the TEK/Science Common Ground is a novel

realization in current academia and education.

Table 1 Comparing the NGSS NOS concepts (NGSS Lead States, 2013) and Stephens' (2001) TEK/Science Common Ground.

\begin{tabular}{|c|c|}
\hline NGSS NOS Middle School Learning Expectations & $\begin{array}{c}\text { TEK/Science Common } \\
\text { Ground }\end{array}$ \\
\hline $\begin{array}{l}\text { Science is a Way of Knowing } \\
\text { - Science is both a body of knowledge and the processes and } \\
\text { practices used to add to that body of knowledge. } \\
\text { Science knowledge is cumulative and many people, from } \\
\text { many generations and nations, have contributed to science } \\
\text { knowledge. } \\
\text { Science is a way of knowing used by many people, not just } \\
\text { scientists. }\end{array}$ & $\begin{array}{l}\quad \text { Organizing } \\
\text { Principles } \\
\text { - } \quad \text { Universe is unified } \\
\text { Body of knowledge } \\
\text { stable but subject to } \\
\text { modification }\end{array}$ \\
\hline $\begin{array}{l}\text { Scientific Knowledge Assumes an Order and Consistency } \\
\text { in Natural Systems } \\
\text { Science assumes that objects and events in natural systems } \\
\text { occur in consistent patterns that are understandable through } \\
\text { measurement and observation. } \\
\text { - Science carefully considers and evaluates anomalies in data } \\
\text { and evidence. }\end{array}$ & \begin{tabular}{l}
\multicolumn{1}{c}{ Knowledge } \\
- \\
Plant and animal \\
behavior \\
- Cycles \\
- $\quad$ Habitat needs \\
- $\quad$ Interdependence \\
- $\quad$ Properties of objects \\
and materials \\
Position and motion of \\
objects \\
Cycles and changes in \\
earth and sky
\end{tabular} \\
\hline $\begin{array}{l}\text { Science is a Human Endeavor } \\
\text { - Men and women from different social, cultural, and ethnic } \\
\text { backgrounds work as scientists and engineers. } \\
\text { Scientists and engineers rely on human qualities such } \\
\text { as persistence, precision, reasoning, logic, imagination and } \\
\text { creativity. } \\
\text { Scientists and engineers are guided by habits of mind such as } \\
\text { intellectual honesty, tolerance of ambiguity, skepticism and } \\
\text { openness to new ideas. } \\
\text { Advances in technology influence the progress of } \\
\text { science and science has influenced advances in } \\
\text { technology }\end{array}$ & $\begin{array}{ll} & \text { Habits of Mind } \\
\text { - } & \text { Honesty } \\
\text { - } & \text { Inquisitiveness } \\
\text { - } & \text { Perseverance } \\
\text { - } & \text { Open-mindedness }\end{array}$ \\
\hline
\end{tabular}


Table 1 Continued

Science Addresses Questions About the Natural and Material World

- Scientific knowledge is constrained by human capacity, technology, and materials.

- Science limits its explanations to systems that lend themselves to observation and empirical evidence.

- Science knowledge can describe consequences of actions but is not responsible for society's decisions.

None directly associated, although traditional ecological knowledge exhibits these qualities.

The objective of this research is to assess the impact of Version 2 explicit

NOS instruction through the incorporation of traditional ecological knowledge into

STEM summer camp curriculum on middle school students' understanding of specific NGSS NOS concepts.

Two tribal summer youth camps in the Northwest were selected. Culturallyappropriate relationship building was important through this process. In partnership with tribal communities, qualitative and quantitative data were collected from participants in two middle school summer camps with TEK and/or STEM focus. The Nez Perce Tribe PACE Math and Science Camp focused primarily on STEM and the Columbia River Inter-Tribal Fish Commission Salmon Camp shared a TEK-STEM emphasis. The characteristics commonly exhibited in culturally-responsive and culturally-relevant curriculum were prevalent in the associated camps, yet typical NOS assessments are not considered culturally-responsive. No Version 1 explicit NOS instruction was planned or documented throughout camp activities and evaluation. Camp participants demonstrated their understating of specific NGSS NOS concepts and ability to categorize knowledge bases through the pre/post survey (Appendix B) and work samples (examples at 
Appendix C). The pre/post survey was two parts, 1) Likert-scale (strongly disagree to strongly agree) with statements developed from NOS crosscutting concepts, and 2) categorizing the knowledge base (TEK, science, both, or neither) given a Common Ground/NOS concept. The development of guiding work samples was in close collaboration with the camp coordinators, adapting to the format of each camp (daily worksheet or camp poster). The work sample prompt followed the format of a) reflect on the day's camp activities, b) select and illustrate/write about three keywords (derived from the NGSS NOS concepts and aligned TEK/Science Common Ground concepts) that were demonstrated or related to the day's camp activities, c) categorize the knowledge base (TEK, STEM, both, or neither).

Intentional focus on Version 2 explicit instruction of NOS concepts was never the objective of the selected summer camps, although the incorporation of TEK serves as a mode of instruction that demonstrates Version 2 components; the components of each camp are further discussed in later sections of this paper. The camps were primarily focused on culturally-relevant experiences to increase interest in the STEM fields for youth from tribal communities and/or strengthen cultural identity. Aside from NOS benefits of incorporating TEK into STEM education there are lessons and best practices rooted in the knowledge itself: place-based education, intergenerational, hands-on, culturally-relevant and responsive, environmental education, sustainability, epistemological diversity, community engagement, applied learning, environmental literacy, history, storytelling, cross-cultural, cultural and academic identity, and decolonizing education. Traditional ecological knowledge builds our knowledge 
portfolio with emphasis on holistic systems thinking for the social, economic, and environmental sustainability for future generations (Reid et. al. 2006). 
Literature Review

The Nature of Science and traditional ecological knowledge are bases of knowledge comprised of distinctive and shared principles. All-inclusive definitions of each knowledge base are difficult to develop. Therefore, examining and honoring the core statements is necessary in understanding the structural concepts of each knowledge base. Statements that are the focus of this research lie in the TEK/STEM Common Ground principles — the shared foundations of TEK and Western science, which in fact align with specific NGSS NOS concepts. Incorporating TEK into STEM curriculum and assessing the impact on students' understanding of NOS serves as an opportunity to diversify and progress our education system.

The following sections provide a review of current literature available on the constructs of this research:

1. The Nature of Science: explicit teaching of the concepts and assessment

2. Traditional ecological knowledge: integration into STEM education

3. Indigenous youth and culturally-relevant education: academic disparities and Native learning styles

4. NOS and culturally-responsive assessments

\section{Nature of Science}

The Nature of Science describes the characteristics and foundations of science knowledge - what is science, how is science done, who does science, etc. (McComas 1998). Duschl and Grandy describe "science education is also and importantly about how we know and why we believe what we know over alternatives; e.g., the cognitive, epistemic, and social discourse practices that characterize science" (p. 2130). Again, 
reverting back to the opening question, "what is science?" educators and scientists alike have their own explanations. For over forty years the US National Science Teacher Association (NSTA) has delivered position statements on science education and curriculum development. In 1964 NSTA stated "science is a systematic and connected arrangement of knowledge within a logical structure of theory. Science is also a process of forming such a structure" (Duschl \& Grandy, 2013, p. 2135). In 2000, NSTA released a position statement on the Nature of Science directing:

"All those involved with science teaching and learning should have a common, accurate view of the nature of science. Science is characterized by the systematic gathering of information through various forms of direct and indirect observations and the testing of this information by methods including, but not limited to, experimentation. The principal product of science is knowledge in the form of naturalistic concepts and the laws and theories related to those concepts..." This statement (the preamble) covers some of the foundational principles of NOS, but not all. Without a concise definition of NOS, it is pertinent to address the structural statements that compose NOS. Niaz (2009) states "a certain degree of consensus has been achieved within the science education community [such that] the nature of science can be characterized, among others, by the following aspects...

1. Scientific knowledge relies heavily, but not entirely, on observations, experimental evidence, rational arguments, and skepticism.

2. Observations are theory-laden.

3. Science is tentative/fallible.

4. There is no one-way to do science and hence no universal, recipe-like, step-bystep scientific method can be found. 
5. Laws and theories serve different roles in science and hence theories do not become laws even with additional evidence.

6. Scientific progress is characterized by competition among rival theories.

7. Different scientists can interpret the same experimental data in more than one way.

8. Development of scientific theories at times is based on inconsistent foundations.

9. Scientists require accurate record keeping, peer review, and replicability.

10. Scientists are creative and often resort to imagination and speculation.

11. Scientific ideas are affected by their social and historical culture.” (p. 45).

Each of the eleven statements serves to describe the practices and conceptual

foundations of science. International attention to NOS in science curriculum is an

increasing trend, even gaining some policy support in countries like Ireland (McComas \& Olson, 1998; Branch, 2013; Dagher \& Erduran, 2016). The benefits of accurately and effectively teaching the NOS were summarized by Clough (2012) as improving students' interest and understanding of science concepts and the role of science in social decisionmaking. Establishing NOS standards unfortunately has not translated into curriculum and instruction as recommended, and school students' understanding of the Nature of Science is still generally poor (Lederman, 2007; Deng et al., 2011).

The Next Generation Science Standards (NGSS) are a set of state science standards based on the National Research Council's A Framework for K-12 Science Education (Framework) (2012) and includes components of the Nature of Science (NGSS Lead States, 2013, Appendix H). In initial drafts of the Framework, public comments advocated for specific discussion about NOS student learning (NGSS Lead States, 2013 Appendix H). The NOS section provided in NGSS provides appropriate grade-level outcomes of eight NOS understandings, which are included as extensions of the science 
and engineering practices and crosscutting concepts. The NOS concepts recognized in NGSS are:

1. Scientific Investigations Use a Variety of Methods

2. Scientific Knowledge is Based on Empirical Evidence

3. Scientific Knowledge is Open to Revision in Light of New Evidence

4. Scientific Models, Laws, Mechanisms, and Theories Explain Natural Phenomena

5. Science is a Way of Knowing

6. Scientific Knowledge Assumes an Order and Consistency in Natural Systems

7. Science is a Human Endeavor

8. Science Addresses Questions About the Natural and Material World

The eight understandings compare with Niaz's compiled eleven statements. The first four understandings are closely associated to NGSS practices and the last four are related to crosscutting concepts. In NGSS, explicit instruction of NOS is recommended such that it "emphasizes why explanations are based on evidence, that the phenomena they observe are consistent with the way the entire universe continues to operate, and that we can use multiple ways to investigate these phenomena.... (and) that students must have the opportunity to stand back and reflect on how the practices contribute to the accumulation of scientific knowledge" (NGSS Lead States, 2013, Appendix H, p. 7-8). Throughout NGSS the NOS understandings are referenced to in the performance expectations and foundations for each grade-level, yet there is minimal guidance on NOS instruction.

The manner in which NOS is taught is an ongoing debate revolving around implicit and explicit instruction (Palmquist \& Finley, 1997; Bell, Lederman, \& Abd-ElKhalick, 1998). Implicit NOS teaching means no direct instruction of NOS concepts, but instead the concepts are demonstrated and practiced through hands-on, and inquiry- based instruction (Palmquist \& Finley, 1997; Bell, et al., 1998). Explicit teaching focuses on 
NOS concepts as cognitive instructional outcomes, rather than affective, and are addressed through direct explanations of the concepts in relation to science content. Kishfe \& Abd-El-Khalick (2002) demonstrate the effectiveness of explicit and reflective inquiry-oriented NOS instruction over implicit inquiry-oriented instructional methods for NOS concepts, explaining the false "assumption that students would automatically learn about NOS through engagement in science-based inquiry activities" (p. 551). Duschl and Grandy's analysis, “Two Views of Explicitly Teaching the Nature of Science” (2013) delves into a further misconception/miscommunication between scholars and educators. They point out the word "explicit" itself is not explicit, and characterize two versions of what "explicit" means. Version 1 of explicit teaching methods is characterized by consensus-based heuristic principles, while Version 2 describes building and refining model-based scientific practices. In Version 1 explicit teaching distinctions include individual scientists' justification of knowledge, exhibits a theory and law approach, and partitioning of philosophy, psychology, and sociology. Conversely, Version 2 is grounded in group activities that focus on cognitive, material, and mechanistic practices, exhibits a model-based approach, and alignment with philosophy, psychology, sociology, and anthropology (table 2 below). The researchers conclusively argue that "Version 2 is to be preferred over Version 1 because it develops the critical epistemic cognitive and social practices that scientists and science learners use when (1) developing and evaluating scientific evidence, explanations and knowledge and (2) critiquing and communicating scientific ideas and information; thereby promoting science literacy" (Duschl \& Grandy, 2013, p. 2109). 
Table 2 Comparison of Version 1 and Version 2 explicit teaching methods of the Nature of Science (Duschl \& Grandy, 2013).

\begin{tabular}{|l|l|}
\hline \multicolumn{1}{|c|}{ Version 1 } & \multicolumn{1}{|c|}{ Version 2 } \\
\hline $\begin{array}{l}\text { Grounded in dated (logical positivism and } \\
\text { historical turn) views that depict NOS through } \\
\text { heuristics that focus on individual scientists } \\
\text { justification of knowledge }\end{array}$ & $\begin{array}{l}\text { Grounded in contemporary (naturalized } \\
\text { philosophy of science) views that depict NOS } \\
\text { through group activities that focus on cognitive, } \\
\text { material, and mechanistic practices }\end{array}$ \\
\hline $\begin{array}{l}\text { Dominated by philosophical views based on } \\
\text { physics }\end{array}$ & $\begin{array}{l}\text { Inclusive of philosophical views from a range of } \\
\text { science disciplines }\end{array}$ \\
\hline Domain-general orientation of NOS-heuristics & $\begin{array}{l}\text { Domain-specific orientation of NOS- disciplinary } \\
\text { practices }\end{array}$ \\
\hline $\begin{array}{l}\text { Inquiry teaching in lessons and activities that } \\
\text { demonstrate learners' consensus 'Features' of } \\
\text { NOS }\end{array}$ & $\begin{array}{l}\text { Learning/doing situated in longer instructional } \\
\text { sequences that engage learners with scientific } \\
\text { practices }\end{array}$ \\
\hline $\begin{array}{l}\text { Tactics and strategies of scientists less prevalent or } \\
\text { missing }\end{array}$ & $\begin{array}{l}\text { Tactics and strategies of scientists more prevalent } \\
\text { or central }\end{array}$ \\
\hline $\begin{array}{l}\text { Core discourse practices of science missing-(e.g., } \\
\text { measurement, representation, observation, and } \\
\text { evaluating evidence/explanation) }\end{array}$ & $\begin{array}{l}\text { Core discourse practices of science central-(e.g., } \\
\text { talk/argument, models/representations; critique } \\
\text { and communication) }\end{array}$ \\
\hline $\begin{array}{l}\text { Curriculum and instruction not aligned with } \\
\text { assessment of learning formats }\end{array}$ & $\begin{array}{l}\text { Curriculum and instruction aligned with } \\
\text { assessment for learning formats }\end{array}$ \\
\hline $\begin{array}{l}\text { Theory and law approach } \\
\text { Partitioning of philosophy, psychology and } \\
\text { sociology. Ignores anthropology }\end{array}$ & $\begin{array}{l}\text { Model-based approach } \\
\text { and anthropology }\end{array}$ \\
\hline $\begin{array}{l}\text { History of Science cases emblematic and episodic } \\
\text { renditions }\end{array}$ & $\begin{array}{l}\text { History of science cases holistic and complex } \\
\text { ranghy }\end{array}$ \\
\hline
\end{tabular}

Educators struggle with how to incorporate NOS concepts explicitly into the classroom (Branch, 2013), and when it is included, Duschl and Grandy (2013) note Version 1 explicit instruction as "fitting with existing modularized disconnected science education curricula that prevail in most schools at the moment..." (p. 2126). Although they also recognize the shift that NGSS may bring and declare "doing science and using knowledge affords opportunities to enact an alternative version of explicitly teaching 
NOS" (p. 2126), NGSS continues to perpetuate Version 1 explicit instruction. One example from NGSS Appendix H (2013) describes:

"Suppose students observe the moon's movements in the sky, changes in seasons, phase changes in water, or life cycles of organisms. One can have them observe patterns and propose explanations of cause-effect. Then, the students can develop a model of the system based on their proposed explanation. Next, they design an investigation to test the model. In designing the investigation, they have to gather data and analyze data. Next, they construct an explanation using an evidence based argument. These experiences allow students to use their knowledge of the practices and crosscutting concepts to understand the nature of science. This is possible when students have instruction that emphasizes why explanations are based on evidence, that the phenomena they observe are consistent with the way the entire universe continues to operate, and that we can use multiple ways to investigate these phenomena" (p. 7).

Although a model-based approach is described for the content in this example, the NOS concepts are communicated through the direct instruction of the teacher, and can be identified as Version 1 explicit teaching where "teachers explicitly link the consensus statements to features of science lessons and activities" (Duschl and Grandy, 2013 p. 2113). Limited examples and guidance for Version 2 explicit NOS instruction have been suggested although the Next Generation Science Standards serve as an avenue for its implementation. 
As educators, scientists, indigenous people, and a competitive society, we have the opportunity to enact an effective version of teaching NOS explicitly. This research aims to understand an alternative version of explicitly teaching NOS through the incorporation of traditional ecological knowledge (TEK) in STEM education. TEK integration in STEM exemplifies Version 2 explicit NOS instruction as described by Duschl and Grandy (2013) and will be further described in the next section on TEK.

\section{Traditional Ecological Knowledge}

Like the Nature of Science, traditional ecological knowledge doesn't have a single definition. As an indigenous person, it is respectable to embrace a definition developed by those who hold and practice traditional ecological knowledge. The Dene Cultural Institute, based in Canada and representing the Dene people and culture since 1987, offers this definition:

"Traditional environmental knowledge is a body of knowledge and beliefs transmitted through oral tradition and first-hand observation. It includes a system of classification, a set of empirical observations about the local environment, and a system of self-management that governs resource use. Ecological aspects are closely tied to social and spiritual aspects of the knowledge system. The quantity and quality of TEK varies among community members, depending upon gender, age, social status, intellectual capability and profession (hunter, spiritual leader, healer, etc.). With its roots firmly in the past, TEK is both cumulative and dynamic, building upon the experience of earlier generations and adapting to the new technological and socioeconomic changes of the present." 
(Dene Cultural Institute 1995 in English translation, quoted in Stevenson 1996 (p. 281).

Although TEK is valued comparable to Western science in the literature (Berkes, 1993; Doubleday, 1993; Turner et al., 2000), it is distinct from NOS in that it requires engagement of indigenous elders. Elders regard the qualities of TEK as holistic, intuitive, qualitative, transmitted intergenerationally by oral tradition, governed by Supreme Being, moral, spiritual, based on mutual well-being, reciprocity, and cooperation, non-linear, often contextualized within the spiritual, communal, and promoting of stewardship (Clayoquot Sound Scientific Panel 1995:14).

Traditional ecological knowledge is respected by government agencies like the US Fish and Wildlife Service (2011), NASA (Roehrig, Campbell, Dalbotten, \& Varma, 2012), and the US Environmental Protection Agency (2011) who incorporate TEK into environmental science, policy, and decision-making. TEK continues to be incorporated into modern applied science, such as medicine, architecture, engineering, ecology, biology, geology, and climatology (Snively \& Corsiglia, 2001). These TEK supporting agencies have been working with scientists who conceptualize their work as a systems approach to earth science (Roehrig, et al., 2012). They call for new educational approaches that focus on interdisciplinary methodologies to STEM teaching (Brophy et al., 2008), and continue to advocate for alignment of science education with Native epistemology that is beneficial to Native and non-native students alike (Snively \& Corsiglia, 2001). As part of the Handbook for Culturally Responsive Science 
Curriculum, Stephens (2001) developed the TEK/Science Common Ground diagram (figure 1).

The TEK/Science Common Ground diagram captures distinct characteristics of TEK and Western science and the Common Ground, which includes organizing principles (e.g., ideas such as that the body of knowledge is stable but subject to modification or developing an understanding of the relationships between science and the social and environmental contexts of science and technology); habits of mind (e.g., holistic); skills and procedures (e.g., observation), and knowledge (e.g., animal behavior) (Stephens, 2001). The TEK/Science Common Ground principles were developed to support more culturally responsive curricula, and the developed diagram only provides a compelling model of the TEK/Science interface. The model has been described by Aikenhead and Ogawa (2007) as "a more reasonable way of comparing the two ways of knowing than other models that place them as binary opposite" (p. 12). They also critiqued the TEK/Science Common Ground diagram for its Eurocentric and lay-oriented language, misrepresented historical-political contexts, devaluing of wisdom, and ambiguity/unauthentic concepts of traditional (culture). These critiques are applauded and considered in the development of this research, although it is beyond the scope of this paper. The focus remains on the TEK/Science Common Ground foundations (Stephens, 2001) and their connection to the specific NGSS NOS Middle School Learning Expectations.

Organizing Principles (Stephens, 2001): Regardless of a holistic approach or a study of a part of or a whole system, both knowledge bases rely upon the fact that the 
universe we study is unified, and all things are connected. As a result, the knowledge is stable in that it is based on this unified system, yet it is everchanging as our understandings evolve through our interaction with and investigation of the system. This principle aligns with the NGSS NOS Middle School Learning Expectation "science is both a body of knowledge and the processes and practices used to add to that body of knowledge, (NGSS Appendix H, p. 6)" while the other two NGSS NOS concepts under Science is a Way of Knowing express the diversity of people who contribute and practice science. The latter two concepts are inherently expressed through the basis of TEK as being an indigenous knowledge based on generations of wisdom passed down through oral tradition, stories, and continued practices.

Knowledge (Stephens, 2001): the TEK/Science Common Ground and NGSS NOS concepts do emphasize knowledge based on natural systems. The TEK/Science Common Ground specifically relies on consistent plant and animal behavior, natural cycles, and properties and motion of objects. The NGSS NOS concepts associated under "Scientific Knowledge Assumes an Order and Consistency in Natural Systems" describe that science assumes consistent patterns in natural systems, which can be measured and observed. Conversely, how the knowledge is integrated and applied in one's daily life differs drastically.

Habits of Mind (Stephens, 2001): The motivations of inquiry for the knowledge bases are unique (practical application of skills and knowledge versus understanding), yet the characteristics of honesty, inquisitiveness, perseverance, and open-mindedness are necessary for progress (TEK/Science Common Ground). The NGSS NOS concepts 
under "Science is a Human Endeavor" describe these characteristics through the emphasis of diversity in science and human qualities like persistence and creativity, honesty and skepticism, and accepting that technology influences progress and progress influences technology.

While the United States education standards continue to place emphasis on NOS concepts in science education, little incorporation of TEK has been detailed regarding the NOS and/or TEK/Science Common Ground principles. The Canadian Council of Ministries of Education (1997) describe four foundations in the Common Framework of Science Learning Outcomes $K$ to 12 for increasing students' science literacy. The foundations are analogous to the TEK/Science Common Ground Principles, and are noted as: 1) Science, technology, society, and the environment; 2) Habits of mind; 3) Skills and procedures; and 4) Knowledge. Four of the ten Canadian provinces explicitly stated the positive impact of incorporating TEK into their curriculum documents in their annual reports (Kim \& Dionne, 2014), and McGregor (2000) reported improvement in Aboriginal students' interest in science when piloting her coexistence model in northern Saskatchewan. The coexistence model promotes the functionality of both indigenous knowledge and Western science, encouraging “equality, mutual respect, support, and cooperation" (McGregor, 2000, p. 454). A more comprehensive description of TEK in science education explains, "the introduction of aboriginal examples [TEK] adds interest and excitement to the science classroom. All students need to identify and debate the strengths and limitations of different approaches in order to explore how others experience the world, and broaden their understanding of the nature of science. A critical 
approach to teaching science can be used to help confront and eliminate racism, ignorance, stereotyping, prejudice and feelings of alienation. All students need to be encouraged to examine their own taken-for-granted assumptions and to distinguish between those that reflect perfectly natural and appropriate cultural preferences and those that are rooted in misinformation or an unwillingness to allow for the existence of alternative perspectives" (Snively, 1995, p. 68).

When TEK is incorporated, it broadens the horizons of students from the dominant culture and validates the inclusion of indigenous students (Aikenhead, 2006; Snively \& Corsiglia, 2001). The Rekindling Traditions project developed teaching units with Western science content taught through the context of the local indigenous community, with success in increasing student interest in science (i.e. synthetic materials used for making modern snowshoes), while also increasing their cultural identity and self-esteem (Aikenhead, 1997). Kimmerer (2002) asserts that in her experience of incorporating TEK into formal education, "students receive cross-cultural views with great enthusiasm" (p.436). Yet, in indigenous communities TEK is scarcely employed in formal education, and even less in the broader non-indigenous education systems (Bang \& Medin, 2010; McCarter \& Gavin, 2011).

There are some deeply rooted barriers though in incorporating TEK broadly in science education. Understanding the history of indigenous people and formalized education requires acknowledgement of the past atrocities (i.e. forced assimilation) and the continued systematic development of power structures favoring the dominant culture (Bang \& Medin, 2010; Aikenhead, 2010). As a result, a "culture clash between 
Aboriginal identities [Canada] and Western science ideologies is severe for most students" (Aikenhead, 2010, p. 387). Among other socioeconomic barriers for indigenous populations, this "culture clash" is experienced worldwide and influences the prominent classroom achievement gap in indigenous (American Indian/Alaska Native, First Nation, Aboriginal) students and the ongoing underrepresentation of indigenous populations in the STEM fields (Australian Government, 2016; NACME, 2014; NSF 2011). Aikenhead (2006) calls out the systematic racism embedded in the language, texts, and representation in science and directs our attention and action to address the "tokenism, indoctrination, and neo-colonialism" (p. 388). The long-standing history can be reconciled through collaborative recognition of the social obstructions preventing progress. Although in-depth discussion about the social obstructions is beyond the focus of this paper, McCarter and Gavin (2011) provide more detailed examples (e.g. concerns that TEK incorporation could lower the value of formal education because the metaphysical aspect of TEK and the integrity of TEK could be diminished through the institutionalization of the knowledge).

Despite the barriers, the need and opportunity for incorporating TEK into science curricula is undeniable. Curriculum has been developed with varying goals spanning from the acknowledgement of TEK to the deconstruction of prejudices through the authentic incorporation and respect for TEK in formal education (Snively \& Corsiglia, 2001). In reviewing TEK incorporation in curriculum in Canada, Kim and Dionne (2014) considered the level of acknowledgment of the education values of TEK, the involvement of Aboriginal scholars and Elders in designing the curricula, the importance 
placed on TEK content per the priority scale they developed, and the policy frameworks for integrating TEK into science education. Foundational information about authentic TEK transmission (both conceptual and practical) is seriously omitted from the literature, although Ruddle (1993) suggests turning to the traditional teachings of TEK for "crucial guidelines for the design and implementation of extension and training programs" (p. ii).

Consistent generalizations of TEK transmission have been summarized as having gender and age specificity for activities, distinct role of and relationship with teachers, a simple to complex teaching sequence, and place based and time specificity (i.e. seasonality) conditions (Ruddle and Chesterfield, 1977). Recognizing the depth of TEK transmission, simplification for the purpose of incorporating TEK into science education resulted in the synthesis of the "cosmopolitan domains of TEK" describing both conceptual knowledge and practical skills (Zent, 2008). Hamlin (2013) modified Zent's (2008) list and further provides suggestions for connections of the domains to scientific disciplines (i.e. ecology, astronomy).

Table 3 The cosmopolitan domains of traditional ecological knowledge (Hamlin, 2013).

\begin{tabular}{|l|l|}
\hline \multicolumn{2}{|c|}{ Cosmopolitan domains of traditional ecological knowledge } \\
\hline \multicolumn{1}{|c|}{ Conceptual knowledge } & \multicolumn{1}{c|}{ Practical skills } \\
\hline $\begin{array}{l}\text { Plants and animals - cultural use or } \\
\text { significance; indigenous names; } \\
\text { taxonomic names and identifications; } \\
\text { characteristics such as morphology, } \\
\text { behavioral habits, life cycle traits, habitat }\end{array}$ & $\begin{array}{l}\text { Resource production and procurement- } \\
\text { this includes agriculture, animal } \\
\text { husbandry, herding, hunting, fishing, or } \\
\text { collecting }\end{array}$ \\
\hline $\begin{array}{l}\text { Plant and animal relationships-cultural } \\
\text { use and/or significance; type of } \\
\text { relationship such as food source, shelter, } \\
\text { protection, dispersal agent; effect of } \\
\text { relationship is it beneficial, harmful, or } \\
\text { neutral }\end{array}$ & Food preparation \\
\hline
\end{tabular}


Table 3 (Continued)

\begin{tabular}{|l|l|}
\hline $\begin{array}{l}\text { Biotypes and landscapes-cultural use } \\
\text { and/or significance; indigenous names; } \\
\text { characteristics such as elevation, } \\
\text { topography; architecture; indicator species }\end{array}$ & $\begin{array}{l}\text { Ethno-medical preparation and } \\
\text { application }\end{array}$ \\
\hline $\begin{array}{l}\text { Soil_cultural use and/or significance; } \\
\text { indigenous names; characteristics such as } \\
\text { color, texture, fertility; agriculture }\end{array}$ & Arts, crafts and tool making \\
\hline $\begin{array}{l}\text { Climate-cultural significance; } \\
\text { indigenous names; descriptors such as } \\
\text { temperature, rain or snow, wind, } \\
\text { humidity; seasons-periods and } \\
\text { indicators; seasonal activities }\end{array}$ & Architecture and construction \\
\hline $\begin{array}{l}\text { Ethno-geography-cultural use and/or } \\
\text { significance; indigenous place names; } \\
\text { location }\end{array}$ & \\
\hline
\end{tabular}

\section{Culturally Responsive and Common Assessment Methods}

\section{Culturally Responsive Assessment Methods}

In 1928, one of the first formal calls for culturally responsive schooling was published in the Meriam Report (Meriam et al., 1928), and "called for more Indigenous teachers, early childhood programs, and the incorporation of tribal languages and cultures in schools" (Castagno \& Brayboy, 2008, p. 945). Gay (2010) describes culturally responsive teaching and how it serves the students and community, while also demonstrating decolonization of the education system:

"Culturally responsive teaching is the behavioral expressions of knowledge, beliefs, and values that recognize the importance of racial and cultural diversity in learning. It is contingent on ... seeing cultural differences as assets; creating caring learning communities where culturally different individuals and heritages are valued; using cultural knowledge of ethnically diverse cultures, families, and 
communities to guide curriculum development, classroom climates, instructional strategies, and relationships with students; challenging racial and cultural stereotypes, prejudices, racism, and other forms of intolerance, injustice, and oppression; being change agents for social justice and academic equity; mediating power imbalances in classrooms based on race, culture, ethnicity, and class; and accepting cultural responsiveness as endemic to educational effectiveness in all areas of learning for students from all ethnic groups" (p. 12). As a component of culturally responsive teaching and curriculum, assessment methods pertaining to Native students have been a topic of discussion since the early 1970’s (Estrin \& Nelson-Barber (1995). Although commonly employed, paper and pencil multiple choice test assessments particularly were identified as deeply problematic and described as being "enmeshed with a larger social system that nourishes... ethnocentrism (Dana, 1984, p.41).” Therefore, culturally responsive assessment methods are a priority for this research.

In Stephen's Culturally Responsive Science Curriculum, the Promising Assessment Strategies (table 4 below) addresses traditional, inquiry, and compatible assessment strategies using diagnostic, formative, and summative approaches (2001, p. 35). The compatible assessment strategies include informal discussions of topic to be studied, concept mapping, informal interviews, journals and learning logs, portfolios, and self-evaluations. 
Table 4 The Promising assessment strategies (Stephens, 2001, p. 35)

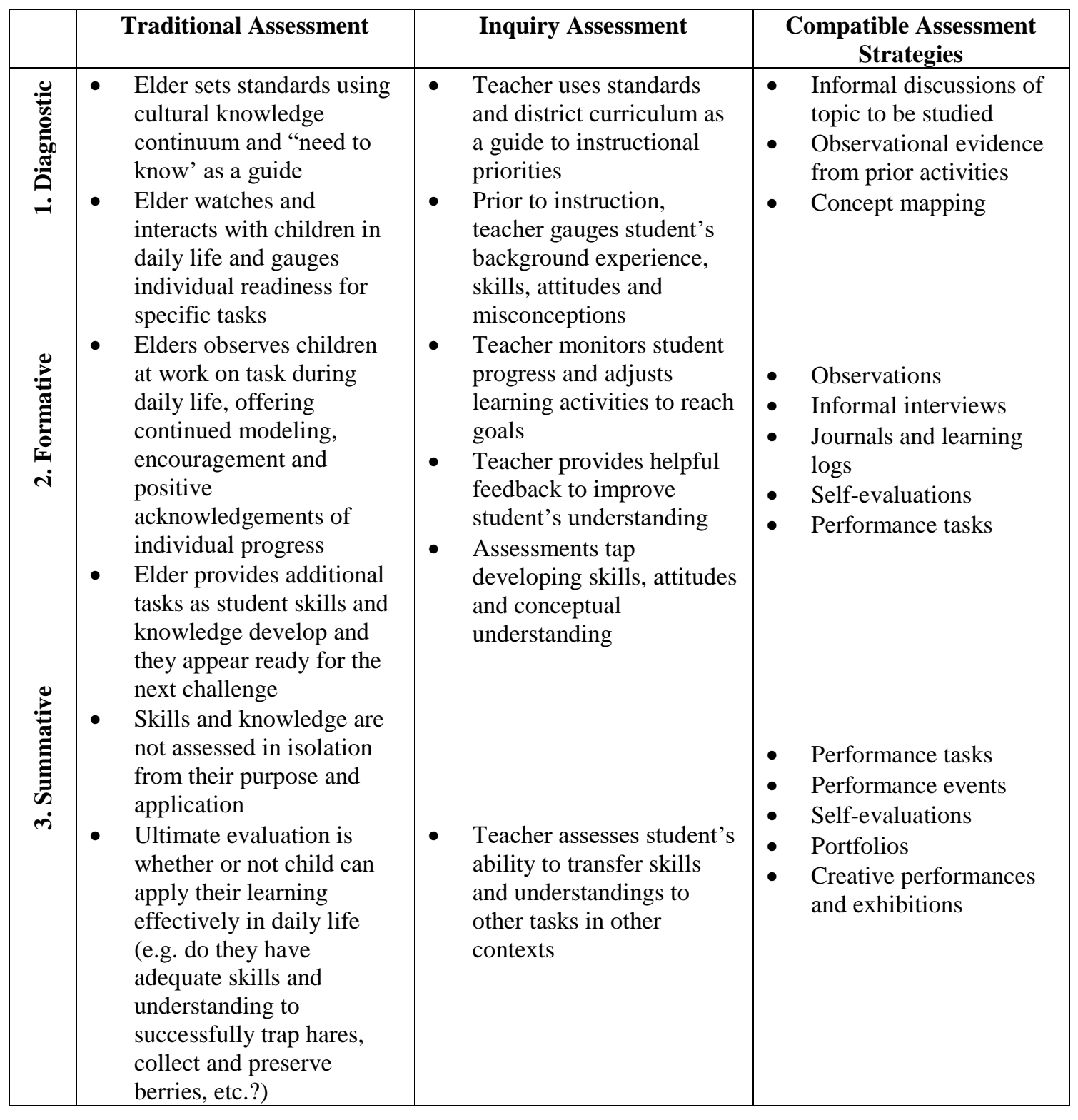

Similarly, Estrin and Nelson-Barber (1995) provide guidelines of culturally

responsive assessment for Native students (table 5 below) and suggest flexibility in

assessment methods. Some noted factors to consider are: "the format of questions

(eliminating multiple choice, for example); how students are grouped (asking cooperative

pairs of children to solve a problem rather than individuals, for example); the pace of an 
assessment task or process; how the language of the instructions is modified by teachers for students; and the language in which an assessment is conducted" (Estrin \& NelsonBarber, 1995, p. 7).

Figure 2 Guidelines for culturally-responsive assessment for Native Students (Estrin \& NelsonBarber, 1995, p. 7).

- Link assessment to instruction. Avoid packaged tests.

- When possible, embed assessment in instruction.

- Tailor content of assessment to students' experiences in and out of school. Use cultural resources with which students are familiar.

- Use open-ended formats (not T/F or multiple choice).

- Allow time for students to process instructions and tackle various aspects of a task.

- Allow students opportunities to practice; give guided practice with multi-step problems.

- Allow time for reflection and deliberation.

- Allow students choices about when they will be assessed and how.

- Provide for cooperation as well as individual assessment opportunities. Allow cooperative problem-solving.

- Use forms of assessment that do not rely entirely on language or mastery of standard English (or uses of language unfamiliar to students).

- Give students explicit information on the purpose and meaning of any standardized tests they must take as well as strategies for responding.

- Treat students as whole people with valid experiences; language and culture are part of a student's identity and way of viewing the world.

- Always document the contexts preceding and surrounding assessment.

Portfolios "foster student reflection, decision-making, goal setting and

engagement in learning; Portfolios can be excellent vehicles for empowering students and representing their learning in terms they understand" (Estin \& Nelson-Barber, 1995, p. 8).

In the National Institute for Learning Outcomes Assessment (2017), portfolios are

highlighted for their demonstration of students' holistic representation of learning, the

option of adding commentary and reflection, and providing a platform for the expression

of conceptual, theoretical, and experiential knowledge attained (Montengro \& Jankowski, 2017). The aspect of self-reflection, which was included in both the Guidelines and the 
Handbook for Culturally Responsive Science Curriculum, is embedded in the process of successful portfolio development (Slater, 2017).

The use of portfolios in this research was based on these recommendations and evidence and serves as student work sample for data collection. The next section discusses instrument used in assessing students' understanding of the Nature of Science.

\section{NOS Assessment Methods}

The first formal assessments of NOS were developed in the 1960's and were founded on a quantitative approach (Lederman, 2007). Through the years, dozens of instruments have been suggested, validated, and researched, all of which assess various aspects of NOS through inventories, questionnaires, scales, and tests NOS (Lederman, 2007). Each instrument has strengths and weaknesses, and Lederman states "clearly, much more work is needed before we, as a research community, can feel confident in making large-scale recommendations to teachers and professional developers" (2007, p. 869). A movement towards more open-ended assessments is necessary, yet there is a collective acceptance of Likert scale items and multiple-choice responses as an "inherent need to make [researchers] lives easier (Lederman, 2007, p. 868)."

The Nature of Scientific Knowledge Scale utilizes a Likert scale instrument focused on six components of NOS— - "amoral, creative, developmental (tentative), parinomious, testable, and unified (Lederman, year, p. 865).” Other studies like the Views of Science Test and Conceptions of Scientific Theories Test, and the Student Understanding of Science and Scientific Inquiry (SUSSI) also utilize Likert scale evaluations. Questions and statements are typically developed with specific focus on 
general NOS concepts (i.e. science is a human endeavor, science is tentative), and the development of the scoring scale for each study is foundational. Moss (2012) provides the scoring template used for this research:

"The Likert-scale responses from the SUSSI were scored on scale of 1 to 5 . If the 'expert' response to a question was Strongly Agree (SA), students responding SA would receive a score of 5 and students responding Strongly Disagree (SD) would receive a score of 1 . Similarly, if the expert response was SD, students responding SD would receive a score of 5 and students responding SA would receive a score of 1 . In this scoring system, positive changes from pre- to post-tests represent students moving toward a more expert view" (p. 14-15).

No formal assessment tool has been developed specifically for the NGSS NOS concepts. For this research these guidelines and statements were referenced in the development of the assessment instruments. 


\section{Methods}

\section{Overview}

The focus of this research is to investigate the impact of incorporating traditional ecological knowledge (TEK) on middle school student's understanding of the Nature of Science. Two summer tribal youth camps were selected for evaluation: the Nez Perce Tribe PACE Math and Science Camp (STEM focused) and the Columbia River InterTribal Fish Commission Salmon Camp (TEK-STEM focused). The NOS constructs assessed were specific to the Next Generation Science Standards NOS concepts (science is a way of knowing, scientific knowledge assumes an order and consistency in natural systems, science is a human endeavor, science addresses questions about the natural and material world (NGSS Lead States, 2013, Appendix H)), and are associated with the TEK/Science Common Ground (the organizing principles, habits of mind, skills and procedures, and knowledge system). To assess students' understanding of NOS concepts, pre/post surveys were administered to camp participants and work samples were generated based on camp activities and keywords generated from NOS concepts. The methods section covers:

1. Setting: Research in Tribal Communities

2. Treatment: Camp Programs

3. Assessment Methods: Survey and Portfolios

4. Data: Collection and Analysis

\section{Setting: Research in Tribal Communities}

With the extensive history of unethical and damaging research with tribal communities, this research was conducted intently through best practices described in the National 
Congress of American Indians (2012) 'Walk softly and listen carefully': Building research relationships with tribal communities. The unique aspects associated with research in tribal communities effectively value indigenous knowledge, the foundational role of culture in research, traditional stewardship that acknowledges Western science, tribal sovereignty when conducting research and managing data, and is beneficial to the tribal community (NCAI, 2012). As such, this research has undergone review and approval from the Nez Perce Tribe, Portland State University Institutional Review Board, as well as a Letter of Support from the Columbia Inter-Tribal Fish Commission, representing the Yakama, Warm Springs, Umatilla, and Nez Perce Tribes (Appendix E).

\section{Nez Perce Tribal Community (PACE Math and Science Camp)}

The Nimiipuu (Nez Perce people) are the indigenous inhabitants across a landscape in Washington, Oregon, Idaho, and Montana reaching 17 million acres historically. The traditional lifeways of the Nimiipuu have been diminished through forced assimilation (Taylor, 2010) and the land base has been reduced down to 750,000 acres through the controversial 1863 "Steal Treaty” (National Park Service, 2015). There are approximately 3,500 enrolled members of the Nez Perce Tribe (CRITFC, 2017), with a reservation population of around 18,000 people (US Census Bureau, 2000). According to the 2000 Census, about $80 \%$ of Nimiipuu had a high school education and $50 \%$ with some college. Despite colonization, the foundations of Nimiipuu culture are still practiced today including hunting, fishing, gathering, ceremonies, songs, language, values like leadership and humor, and the concepts of family structure and connection to 
the environment. For many Nez Perce community members and children, participation in cultural activities is familiar by the age of 12 .

As a researcher, my relationship with the Nez Perce Tribe (NPT) is inherent, as I am an enrolled tribal member, from the community, and have established an academic/professional profile by completing internships within the NPT Environmental Restoration and Waste Management Division (Air Quality Program and US Department of Energy/Hanford) and was employed in the NPT Water Resources Division (Wetland Field Assistant and Water Resource Specialist). Continued community involvement in cultural and environmental protection and education remains a primary life objective. Regarding this research, I have attended the PACE Math and Science Camp as a camp attendee $(2002,2003)$, camp counselor $(2008,2009)$, presenter (2007), and during this research I served as the math curriculum teacher.

\section{CRITFC Tribal Communities (Salmon Camp)}

The Columbia Inter-Tribal Fish Commission was established in 1977 and is comprised of the Confederated Tribes of the Umatilla Indian Reservation, the Confederated Tribes of the Warm Springs Reservation of Oregon, the Confederated Tribes and Bands of the Yakama Nation, and the Nez Perce Tribe. With the US government's historic disregard for tribal treaty rights as determined in 1855 , "[CRIFTC] was established to provide coordination and technical assistance to the tribes in regional, national, and international efforts to ensure that treaty fishing rights issues are resolved in a way that guarantees the continuation and restoration of tribal fisheries into 
Perpetuity" (CRITC, 2017). CRITFC Workforce Development Program, that provides Salmon Camp, is a product of these efforts. Each of the four tribes has unique, yet similar histories and current educational attainments. Shared cultural practices across the four tribes are commonly familiar to community members by age 12 , as mentioned about the Nez Perce Tribe

As a researcher, my relationship with CRITFC has been developed over three years through involvement in the Portland Parks and Recreation Native American Community Advisory Council, with CRITFC staff, and through inherent associations as a Nez Perce tribal member. I have not attended Salmon Camp, so a close working relationship with the camp coordinator was paramount in a successful research

Table 5 Information for the four CRITFC tribes on population, land base, and educational attainment (US Census Bureau, 2000; CRITFC, 2017).

\begin{tabular}{|l|c|c|c|c|c|c|}
\hline \multicolumn{1}{|c|}{ Tribe } & $\begin{array}{c}\text { Tribal } \\
\text { Population }\end{array}$ & $\begin{array}{c}\text { Reservation } \\
\text { Population }\end{array}$ & $\begin{array}{c}\text { Historic Land } \\
\text { Base }\end{array}$ & \multicolumn{1}{c|}{$\begin{array}{c}\text { Reservation } \\
\text { Size (acres) }\end{array}$} & $\begin{array}{c}\text { High } \\
\text { School } \\
\text { or higher }\end{array}$ & $\begin{array}{c}\text { Some } \\
\text { college }\end{array}$ \\
\hline Umatilla & 2,800 & 3,000 & $6.4 \mathrm{M}$ acres & 172,000 & $80 \%$ & $50 \%$ \\
\hline Warm Springs & 5,000 & 3,300 & $10 \mathrm{M}$ acres & 640,00 & $77 \%$ & $37 \%$ \\
\hline Yakama & 10,200 & 32,000 & $11.5 \mathrm{M}$ acres & 1.2 million & $73 \%$ & $38 \%$ \\
\hline Nez Perce & 3,500 & 18,000 & $7.5 \mathrm{M}$ acres & 750,00 & $80 \%$ & $50 \%$ \\
\hline
\end{tabular}

partnership. Salmon Camp is planned through community participation and collaborative efforts with the host tribe - the Confederated Tribes of the Umatilla Indian Reservation (CTUIR) for 2017. The four CRITFC tribes rotate hosting Salmon Camp each year. Attending community meetings and being transparent throughout the process of this research were active methods in strengthening the community support for this research. 
The development of Salmon Camp involved collaboration of CRITFC and CTUIR staff, tribal community members and elders, scientists, and students.

Treatment: Camp Programs

\section{Nez Perce Tribe PACE Math and Science Camp}

The PACE Math and Science Camp is the longest running summer youth camp of the Nez Perce Tribe (20 years) and is developed by the NPT Education Specialist of the Environmental Restoration and Waste Management Division (ERWM). PACE is a twoweek math and science day camp geared towards junior high/middle school age students. The camp focus is on preparing students for high school Algebra and science, and to increase the number of students entering the STEM fields. Academic success in the STEM fields can prepare the future generations in careers relevant to the Nez Perce Tribe's rich natural resources and ensuring we will be able to continue to practice and exercise our Treaty Rights. The target population is twenty-five middle school youth with support from three high school counselors and three college counselors. The camp activities span over ten days with the mornings dedicated to pre-algebra math curriculum (1.5 hours) and an engineering design challenge ( 1.5 hours). The morning portion of camp was held on the Lapwai Middle/High School (MS/HS) campus in Lapwai, Idaho (Nez Perce Reservation). The morning math curriculum (algebra content) is not considered as impacting students' understanding of NOS, therefore no influence on the research is perceived. The afternoons consist of field trips and presentations by professionals and college students in the STEM fields who demonstrate how STEM 
practices and concepts are applied to real-world issues, opportunities in higher education, and career pathways ( 3.5 hours). The afternoon sessions occurred on the Lapwai Middle/High School campus and off-site locations as identified in the camp agenda (Appendix F).

Camp participants were selected based on their camp application which was scored by two NPT employees (the camp coordinator and coordinating assistant). The scoring of applications was based on the following criteria: complete application package, student interest paragraph related to PACE objectives, current grade level, ability to commit $100 \%$ through attendance and participation, and a signed Conduct Code agreement. There were 13 male and 9 female camp participants who are either tribal members or closely associated with the tribal community. The camp counselors were not included as camp participants for data collection. Camp participants received a $\$ 200$ stipend upon 1) $100 \%$ participation in the entire camp and camp activities (no absences and full engagement);2) completion of all math assignments (individual) and the engineering design challenge (group); and 3) an increased score on the math test administered both pre/post.

The components of the camp that were assessed for NOS concepts were the afternoon STEM field trips which innately exhibited NOS concepts, but did not have any direct instruction regarding them. Also, traditional ecological knowledge was not intentionally incorporated throughout PACE and were identified using the domains summarized by Hamlin (2013). In Table 7 below, eleven camp activities are described 
including a visit to a fish hatchery, local university, and on-site visit by geologists (also

view the PACE Schedule for 2017 in Appendix F for full program agenda).

Table 6 Summary of PACE camp activities related to STEM and/or TEK.

\begin{tabular}{|c|c|c|c|c|}
\hline Day & Instructor & $\begin{array}{l}\text { Program } \\
\text { Location }\end{array}$ & Topic & Teaching Methods \\
\hline 1 & $\begin{array}{l}\text { ERWM Education } \\
\text { Specialist }\end{array}$ & $\begin{array}{l}\text { Lapwai } \\
\text { MS/HS } \\
\text { Campus } \\
\end{array}$ & TEK: NPT history; cultural identity & $\begin{array}{l}\text { Reflective activities; } \\
\text { multimedia (videos) }\end{array}$ \\
\hline 2 & $\begin{array}{l}\text { UI Computer } \\
\text { Science Associate } \\
\text { Professor* }\end{array}$ & $\begin{array}{l}\text { UI Dept. of } \\
\text { Computer } \\
\text { Science }\end{array}$ & $\begin{array}{l}\text { Computer programming; software } \\
\text { vs. hardware; modeling and } \\
\text { simulation; artificial intelligence } \\
\text { and robots; Scratch computer } \\
\text { program }\end{array}$ & $\begin{array}{l}\text { Robot demonstration; } \\
\text { hands-on exploration } \\
\text { (programming) }\end{array}$ \\
\hline \multirow{2}{*}{3} & $\begin{array}{l}\text { WSU Crop and } \\
\text { Soil Science } \\
\text { Assistant } \\
\text { Professor/ } \\
\text { Scientist* }\end{array}$ & $\begin{array}{l}\text { Lapwai } \\
\text { MS/HS } \\
\text { Campus }\end{array}$ & $\begin{array}{l}\text { Soil biology; biodiversity; fungi; } \\
\text { earthworms; hissing cockroaches }\end{array}$ & $\begin{array}{l}\text { PowerPoint } \\
\text { presentation; hands- } \\
\text { on exploration } \\
\text { (wet/dry soil } \\
\text { properties; handling } \\
\text { insects) } \\
\end{array}$ \\
\hline & $\begin{array}{l}\text { NPT Bio-Control } \\
\text { Director and } \\
\text { Technician }\end{array}$ & $\begin{array}{l}\text { NPT Bio- } \\
\text { Control } \\
\text { Center }\end{array}$ & $\begin{array}{l}\text { TEK: Cultural significance to } \\
\text { landscapes; Bio-Control agents } \\
\text { (insects); noxious weeds; land } \\
\text { management throughout the NW }\end{array}$ & $\begin{array}{l}\text { Multimedia } \\
\text { presentation (video); } \\
\text { hands-on exploration } \\
\text { (handling insects); } \\
\text { guided tour of } \\
\text { greenhouse } \\
\end{array}$ \\
\hline 4 & $\begin{array}{l}\text { NPT Fisheries } \\
\text { Professional/ } \\
\text { Production } \\
\text { Supervisor }\end{array}$ & $\begin{array}{l}\text { Dworshak } \\
\text { National } \\
\text { Fish } \\
\text { Hatchery }\end{array}$ & $\begin{array}{l}\text { TEK: Cultural significance and } \\
\text { history of NPT and fish species } \\
\text { (salmon, lamprey). Salmon life } \\
\text { cycle; hatchery production; } \\
\text { facilities; and research. }\end{array}$ & $\begin{array}{l}\text { Guided tour of } \\
\text { hatchery; hands-on } \\
\text { activity (feeding fish) }\end{array}$ \\
\hline \multirow[b]{2}{*}{5} & $\begin{array}{l}\text { NPT Air Quality } \\
\text { Environmental } \\
\text { Outreach } \\
\text { Specialists }\end{array}$ & $\begin{array}{l}\text { Lapwai } \\
\text { MS/HS } \\
\text { Campus }\end{array}$ & $\begin{array}{l}\text { Renewable energy; wind mills- } \\
\text { history, types, design, limitations; } \\
\text { design challenge/competition }\end{array}$ & $\begin{array}{l}\text { Presentation; hands- } \\
\text { on exploration } \\
\text { (windmill design } \\
\text { challenge) }\end{array}$ \\
\hline & $\begin{array}{l}\text { PSU Graduate } \\
\text { Student and } \\
\text { Researcher* }\end{array}$ & $\begin{array}{l}\text { Lapwai } \\
\text { Communit } \\
\text { y Garden }\end{array}$ & $\begin{array}{l}\text { Scientific method: making } \\
\text { observations; recognizing patterns; } \\
\text { identifying anomalies; generating a } \\
\text { research question; and developing a } \\
\text { research plan focusing on plant } \\
\text { species found in the local } \\
\text { community garden }\end{array}$ & $\begin{array}{l}\text { Guided observations; } \\
\text { group discussion/ } \\
\text { talking circle; self- } \\
\text { reflection; group } \\
\text { evaluation of } \\
\text { individual research } \\
\text { plans }\end{array}$ \\
\hline 6 & $\begin{array}{l}\text { UI College of } \\
\text { Natural Resources } \\
\text { Graduate } \\
\text { Students* }\end{array}$ & $\begin{array}{l}\text { Lapwai } \\
\text { MS/HS } \\
\text { Campus }\end{array}$ & $\begin{array}{l}\text { Research in fish sciences; fish } \\
\text { anatomy and health }\end{array}$ & $\begin{array}{l}\text { PowerPoint } \\
\text { presentation and } \\
\text { guided observations; } \\
\text { hands-on exploration } \\
\text { (fish dissection) }\end{array}$ \\
\hline
\end{tabular}


Table 6 Continued

\begin{tabular}{|l|l|l|l|l|}
\hline \multicolumn{2}{|c|}{$\begin{array}{l}\text { NPT Cultural } \\
\text { Resources }\end{array}$} & $\begin{array}{l}\text { Lapwai } \\
\text { MS/HS } \\
\text { Campus }\end{array}$ & $\begin{array}{l}\text { Research in wildlife sciences; } \\
\text { tracking of wildlife populations with } \\
\text { radio collars; tagging techniques }\end{array}$ & $\begin{array}{l}\text { Hands-on exploration } \\
\text { (dart gun tagging); } \\
\text { multimedia (video) }\end{array}$ \\
\hline $\begin{array}{l}\text { UI Biological } \\
\text { Science Graduate } \\
\text { Students* }\end{array}$ & $\begin{array}{l}\text { Lapwai } \\
\text { MS/HS } \\
\text { Campus }\end{array}$ & $\begin{array}{l}\text { Video game development; computer } \\
\text { science careers; using technology in } \\
\text { biology and other research }\end{array}$ & $\begin{array}{l}\text { Hands-on exploration } \\
\text { (guided computer } \\
\text { gaming and character } \\
\text { design and } \\
\text { development) }\end{array}$ \\
\hline 8 & $\begin{array}{l}\text { WSU State Dept. } \\
\text { of Ecology } \\
\text { Environmental } \\
\text { Education } \\
\text { Specialist and } \\
\text { Geologists* }\end{array}$ & $\begin{array}{l}\text { Lapwai } \\
\text { MS/HS } \\
\text { Campus }\end{array}$ & $\begin{array}{l}\text { Hanford Nuclear Waste Site; } \\
\text { groundwater and soil } \\
\text { contamination/ protection; rock } \\
\text { cycle; types; and properties; storm } \\
\text { water management }\end{array}$ & $\begin{array}{l}\text { Presentation; hands- } \\
\text { on exploration } \\
\text { (different rock types } \\
\text { and properties) }\end{array}$ \\
\hline
\end{tabular}

*UI is University of Idaho; WSU is Washington State University; PSU is Portland State University

\section{CRITFC Salmon Camp}

Salmon Camp is a product of the Columbia River Inter-Tribal Fish Commission's

(CRITFC) Tribal Workforce Development program and each year is developed in collaboration with community members, professionals, and elders from the host tribe.

Salmon Camp has occurred for six years, beginning in 2010. The annual camp is a weeklong, overnight camp providing tribal middle school students with culturally relevant science, technology, engineering, and mathematics experiences to foster an interest in natural resources careers and close the achievement gap for Native American youth. The camp blends Western science, traditional ecological knowledge, and cultural knowledge and experiences. Students participate on salmon restoration projects, learn about the science and lifecycle of salmon and lamprey, explore local TEK, and meet tribal professionals, college students, and community members working in fisheries. Each year, one of the four CRITFC tribes host Salmon Camp in their community; this year the Confederated Tribes of the Umatilla Indian Reservation (CTUIR) hosted the camp at Emigrant Springs State Heritage Site near Meacham, Oregon. 
The target population is twenty incoming $6^{\text {th }}-8^{\text {th }}$ grade students from the four member tribes (each tribe is permitted five students) with support from four high school youth (junior counselors) and four college counselors. Camp participants were selected based on their camp application which was scored by a selection committee of 2-4 people from CRITFC Watershed Department. The scoring of applications was based on the following criteria: tribal affiliation, grade level, and essay questions about interest in camp, personal interests (favorite classes, extracurricular activities, etc.), and identifying a problem and a potential career pathway that interests the individual. There were 10 male and 10 female camp participants. The camp counselors were not included as camp participants for data collection. Camp participants received a \$100 stipend upon 1) 100\% participation in the entire camp and camp activities; and 2) completion of a poster that was comprehensive in detailing the youths' experience during camp; and 3) presentation of their poster at the community wrap-up events hosted by CRITFC.

The camp activities extended over six days with activities primarily taking place off-site at CTUIR restoration sites, local colleges, and along the Columbia River. The camp was assessed in its entirety for NOS concepts, except for ceremonial activities (sweat). Traditional ecological knowledge was paramount in the camp programming (as noted in the table 8 below) and were identified using the domains summarized by Hamlin (2013). In Table 8 , the instructor, program location, topic, activity objectives, and teaching methods are described for fifteen camp activities (also view the 2017 Salmon Camp Program Agenda in Appendix G). 
Table 7 Summary of Salmon Camp activities relating to STEM and/or TEK.

\begin{tabular}{|c|c|c|c|c|}
\hline Day & Instructor & $\begin{array}{l}\text { Program } \\
\text { Location }\end{array}$ & Topic & Teaching Methods \\
\hline 1 & $\begin{array}{l}\text { Tribal } \\
\text { community } \\
\text { members }\end{array}$ & $\begin{array}{l}\text { Community/ } \\
\text { family sweat } \\
\text { house }\end{array}$ & $\begin{array}{l}\text { TEK: Tribal history and } \\
\text { culture; sweat ceremony; and } \\
\text { team building }\end{array}$ & $\begin{array}{l}\text { Guided participation } \\
\text { in traditional teachings } \\
\text { and songs; hands-on }\end{array}$ \\
\hline \multirow{4}{*}{2} & $\begin{array}{l}\text { CTUIR } \\
\text { Education } \\
\text { Coordinator \& } \\
\text { Fish Biologists }\end{array}$ & $\begin{array}{l}\text { William Grant } \\
\text { Water \& } \\
\text { Environmental } \\
\text { Center at } \\
\text { WWCC* }\end{array}$ & $\begin{array}{l}\text { Lamprey life cycle; tribal } \\
\text { hatchery \& restoration efforts }\end{array}$ & $\begin{array}{l}\text { Guided tour; hands-on } \\
\text { (viewing tanks and } \\
\text { fish feeding; } \\
\text { microscope access) }\end{array}$ \\
\hline & $\begin{array}{l}\text { CTUIR Public } \\
\text { Outreach \& } \\
\text { Education } \\
\text { Specialist }\end{array}$ & $\begin{array}{l}\text { William Grant } \\
\text { Water \& } \\
\text { Environmental } \\
\text { Center at } \\
\text { WWCC }\end{array}$ & $\begin{array}{l}\text { TEK: Cultural significance } \\
\text { and use of mussels; } \\
\text { restoration; ecosystem } \\
\text { services; threats to species; } \\
\text { tribal treaties }\end{array}$ & $\begin{array}{l}\text { Hands-on exploration } \\
\text { (identifying species } \\
\text { (invasive/native, } \\
\text { male/female; } \\
\text { dissection) }\end{array}$ \\
\hline & $\begin{array}{l}\text { CTUIR Tribal } \\
\text { Fish Biologists }\end{array}$ & $\begin{array}{l}\text { Walla Walla } \\
\text { River Habitat } \\
\text { Project Site }\end{array}$ & $\begin{array}{l}\text { TEK: Cultural significance } \\
\text { and use of fish; fish habitat } \\
\text { (4C: complex, cold, } \\
\text { connected, clean); } \\
\text { restoration; } \\
\text { macroinvertebrate sampling; } \\
\text { water quality }\end{array}$ & $\begin{array}{l}\text { Poster presentation; } \\
\text { guided participation; } \\
\text { handouts (macro ID); } \\
\text { hands-on exploration } \\
\text { (macro sampling) }\end{array}$ \\
\hline & $\begin{array}{l}\text { CTUIR Tribal } \\
\text { Public Outreach } \\
\& \text { Education } \\
\text { Specialist }\end{array}$ & $\begin{array}{l}\text { Walla Walla } \\
\text { River Habitat } \\
\text { Project Site }\end{array}$ & $\begin{array}{l}\text { TEK: Cultural significance } \\
\text { and use of traditional plants; } \\
\text { identification of and } \\
\text { connections to fish; } \\
\text { ecosystem connections }\end{array}$ & $\begin{array}{l}\text { Guided tour; fish } \\
\text { hatchery viewing }\end{array}$ \\
\hline \multirow{3}{*}{3} & Tribal Elder & $\begin{array}{l}\text { Celilo Falls Long } \\
\text { House }\end{array}$ & $\begin{array}{l}\text { TEK: Cultural significance } \\
\text { and use of water and place } \\
\text { (ethnogeography); traditional } \\
\text { stories; cultural site history; } \\
\text { importance of tribal identity; } \\
\text { responsibility of future } \\
\text { generations }\end{array}$ & Storytelling \\
\hline & Tribal Elder & $\begin{array}{l}\text { Celilo Falls Site } \\
\text { (Columbia } \\
\text { River) }\end{array}$ & $\begin{array}{l}\text { TEK: Cultural site history } \\
\text { (ethnogeography, } \\
\text { biotype/landscape) and } \\
\text { resource procurement; water } \\
\text { blessing; cultural significance } \\
\text { and use of water and fish; } \\
\text { ecosystem threats }\end{array}$ & Traditional song \\
\hline & $\begin{array}{l}\text { Self-guided/ } \\
\text { Bonneville } \\
\text { Dam Park } \\
\text { Ranger }\end{array}$ & $\begin{array}{l}\text { Bonneville Dam } \\
\text { Visitors Center }\end{array}$ & $\begin{array}{l}\text { Dam construction; Columbia } \\
\text { River history; fish species } \\
\text { and life cycles; fish passages; } \\
\text { viewing windows; fish } \\
\text { monitoring/count; fish } \\
\text { hatchery }\end{array}$ & $\begin{array}{l}\text { Educational kiosks; } \\
\text { oral presentation; } \\
\text { handouts }\end{array}$ \\
\hline
\end{tabular}


Table 7 Continued

\begin{tabular}{|c|c|c|c|c|}
\hline & $\begin{array}{l}\text { Tribal } \\
\text { fisherwoman }\end{array}$ & $\begin{array}{l}\text { Cascade Locks } \\
\text { Park }\end{array}$ & $\begin{array}{l}\text { TEK: Cultural significance } \\
\text { and use of water, fish, and } \\
\text { resource procurement; } \\
\text { traditional fishing; tribal } \\
\text { sovereignty and treaty rights; } \\
\text { family history } \\
\text { (ethnogeography) }\end{array}$ & $\begin{array}{l}\text { Scaffold/dipnet fishing } \\
\text { demonstration }\end{array}$ \\
\hline & $\begin{array}{l}\text { Tribal Elder/ } \\
\text { Politician/ } \\
\text { Fisherwoman }\end{array}$ & $\begin{array}{l}\text { Native Owned } \\
\text { Business/ Tribal } \\
\text { Enterprise }\end{array}$ & $\begin{array}{l}\text { TEK: Cultural significance } \\
\text { and use of fish, resource } \\
\text { procurement, and } \\
\text { ethnogeography; tribal } \\
\text { sovereignty and treaty rights; } \\
\text { family history; regional } \\
\text { politics; entrepreneurship }\end{array}$ & Site tour \\
\hline & $\begin{array}{l}\text { Tribal } \\
\text { fisherwoman/ } \\
\text { men }\end{array}$ & $\begin{array}{l}\text { LePage } \\
\text { (Columbia } \\
\text { River) }\end{array}$ & $\begin{array}{l}\text { TEK: Cultural significance } \\
\text { and use of fish and resource } \\
\text { procurement, and } \\
\text { ethnogeography; traditional } \\
\text { fishing techniques; family } \\
\text { history; tribal sovereignty } \\
\text { and treaty rights; } \\
\text { traditional/modern law }\end{array}$ & $\begin{array}{l}\text { Demonstration of } \\
\text { fishing techniques and } \\
\text { equipment }\end{array}$ \\
\hline \multirow[t]{4}{*}{4} & $\begin{array}{l}\text { CTUIR Fish } \\
\text { Biologist }\end{array}$ & $\begin{array}{l}\text { Meacham Creek } \\
\text { Restoration Site }\end{array}$ & $\begin{array}{l}\text { TEK Cultural significance of } \\
\text { landscape, climate, and } \\
\text { ethnogeography; habitat } \\
\text { restoration; invasive plants } \\
\text { and weed management; water } \\
\text { quality; field data collection } \\
\text { (vegetation transects; water } \\
\text { levels; photo points) }\end{array}$ & $\begin{array}{l}\text { Demonstration; hands- } \\
\text { on exploration; service } \\
\text { learning project }\end{array}$ \\
\hline & $\begin{array}{l}\text { College } \\
\text { Campus Tours }\end{array}$ & $\begin{array}{l}\text { Eastern Oregon } \\
\text { University }\end{array}$ & College Staff & Campus tour \\
\hline & $\begin{array}{l}\text { Camp Staff and } \\
\text { counselors }\end{array}$ & $\begin{array}{l}\text { Eastern Oregon } \\
\text { University }\end{array}$ & Academic Journey & Personal narrative \\
\hline & $\begin{array}{l}\text { Tribal } \\
\text { community } \\
\text { members }\end{array}$ & $\begin{array}{l}\text { Umatilla } \\
\text { Longhouse }\end{array}$ & $\begin{array}{l}\text { TEK: Traditional Meal (food } \\
\text { preparation and serving) }\end{array}$ & $\begin{array}{l}\text { Hands-on; service } \\
\text { learning project }\end{array}$ \\
\hline
\end{tabular}

*WWCC is Walla Walla Community College 


\section{Assessment Methods: Survey and Portfolios}

During the development of the assessment methods employed in this research, culturally responsive considerations were primary. The Guidelines for CulturallyResponsive Assessment for Native Students (Guidelines) (Estrin and Nelson-Barber, 1995 ) and the Handbook for Culturally Responsive Science Curriculum (Handbook) (Stephens, 2001) provided structural components in creating culturally responsive assessment methods specific to the communities, camp setting, and established curriculum. Consent and assent was collected during the application process for camp participants.

Pre/Post NGSS Nature of Science Survey

The survey employed for this research demonstrated these culturally responsive aspects mentioned in the Guidelines (Estrin \& Nelson-Barber, 1995): 1) Give students explicit information on the purpose and meaning of any standardized tests [survey] they must take as well as strategies for responding; 2) Treat students as whole people with valid experiences; language and culture are part of a student's identity and way of viewing the world; and 3) Always document the contexts preceding and surrounding assessment. Although the goal is to have comprehensive culturally responsive approaches to formal education, for the purpose of this research the NGSS NOS Survey was developed using Likert scale responses. Statements from the Nature of Scientific Knowledge Scale (Rubba, 1976), a modified version (Meichtry, 1990)), SUSSI (Liang et al., 2008), and other previously mentioned NOS instruments were reviewed prior to the development of the survey for this research. The NGSS NOS concepts and understandings for middle 
school students guided the production of statements from my peers (graduate cohort), faculty, and myself. There were 109 statements developed initially, and were comprehensively representative of the NGSS NOS understandings. For each NGSS NOS understandings, top statements were selected, compared to statements from other instruments, and confirmed for alignment with NGSS NOS understanding statement as directly stated in Appendix H (2013). These statements comprise Section 2 of the survey and consists of sixteen statements: four addressing "Way of Knowing," four addressing the "Order and Consistency in Nature," five addressing "Human Endeavor," and three addressing the "Natural and Material World."

The survey also contains an introductory section for participants to identify traditional/cultural activities they have engaged in (i.e. ceremony, hunting, fishing, weaving, dancing). The goal was to reinforce that culture is recognized as an asset, and the knowledge valued. Additionally, the final section of the survey was developed from the NGSS NOS understandings as stated in NGSS Appendix H. The statements were modified to state "knowledge" in place of "science" and students were asked if they thought the statement was representing TEK, (Western) science, both, or neither. This line of questioning aims to gauge youth perception of the foundations of the knowledge bases (i.e. Does the statement "knowledge is cumulative (continually built upon from prior knowledge)" relate to TEK, science, both or neither). All statements are related to both, although depending on the depth of understanding of TEK and science foundations, it may not be recognized as the case. So rather, this data is used to represent 
the shift in understanding of the foundational concepts of the TEK and Western science knowledge bases. The survey is displayed below: 
Figure 3 Part I of the survey administered pre and post for both camps.

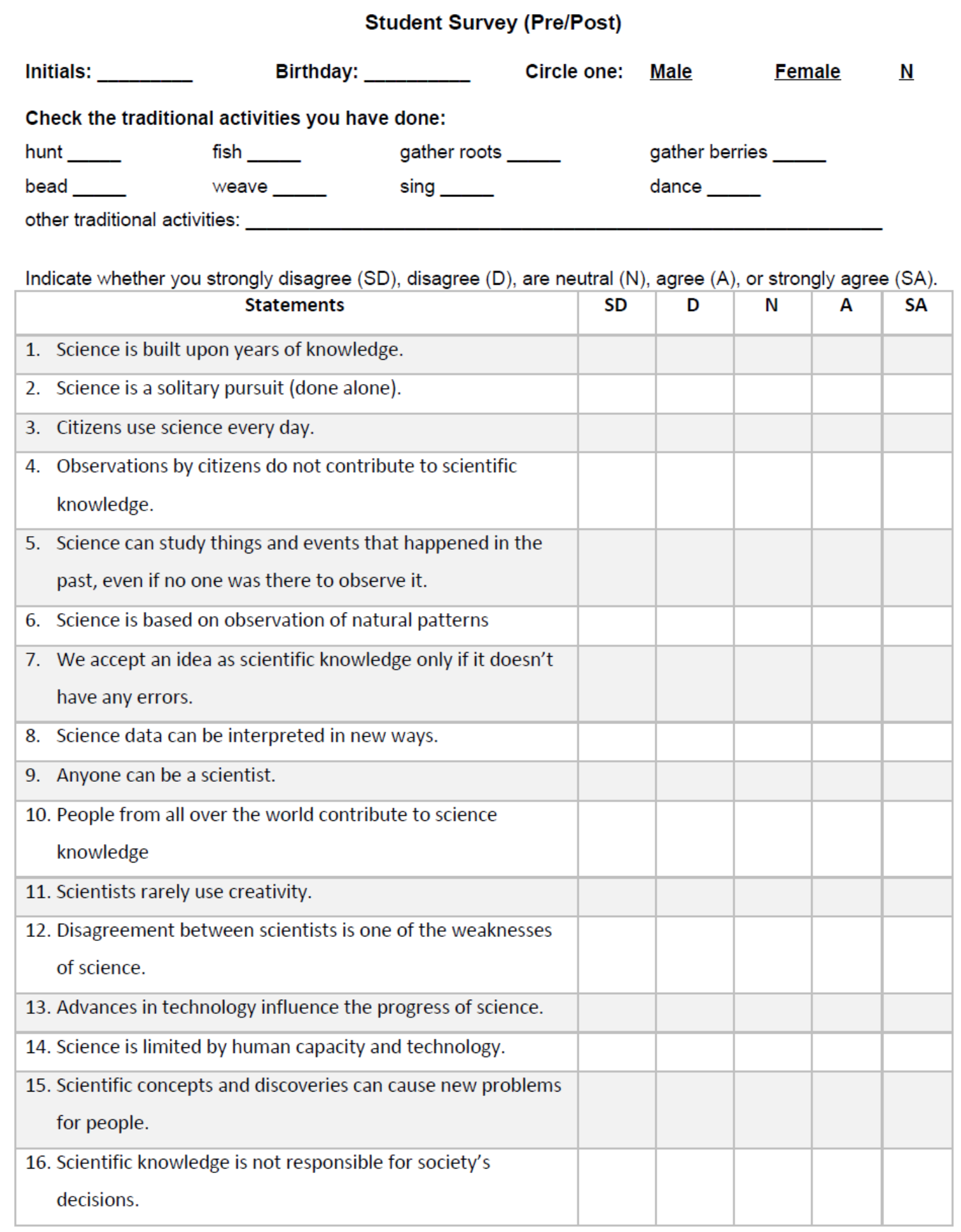


Figure 4 Part II of the survey administered pre and post for both camps.

Student Survey: Indicate whether each statement relates to Traditional Ecological Knowledge/Culture, Science, both, or neither.

\begin{tabular}{|c|c|c|c|c|}
\hline Statements & $\begin{array}{l}\text { Traditional } \\
\text { Knowledge }\end{array}$ & Science & Both & Neither \\
\hline $\begin{array}{l}\text { Knowledge is cumulative (continually built upon from } \\
\text { prior knowledge). }\end{array}$ & & & & \\
\hline $\begin{array}{l}\text { Many people, from many generations and nations, } \\
\text { have contributed to our knowledge. }\end{array}$ & & & & \\
\hline $\begin{array}{l}\text { Different sources of knowledge can be used together } \\
\text { and benefit one another. }\end{array}$ & & & & \\
\hline Patterns in nature can be observed and measured. & & & & \\
\hline $\begin{array}{l}\text { Inconsistencies or changes are considered and } \\
\text { evaluated. }\end{array}$ & & & & \\
\hline $\begin{array}{l}\text { Men, women and people from different backgrounds } \\
\text { engage in building knowledge. }\end{array}$ & & & & \\
\hline Knowledge is based on observation of natural patterns & & & & \\
\hline $\begin{array}{l}\text { Values like persistence, precision, reasoning, logic, } \\
\text { imagination, and creativity are important. }\end{array}$ & & & & \\
\hline $\begin{array}{l}\text { Values like harmony, respect, resiliency, } \\
\text { interdependence, and reciprocity (giving mutually) are } \\
\text { important. }\end{array}$ & & & & \\
\hline
\end{tabular}

\section{Portfolios}

The portfolios served as log of the knowledge camp youth were gaining and how they categorized that knowledge (TEK, Western science, both, or neither). The portfolios were designed in cooperation with the camp coordinators in which we aimed to incorporate the portfolio into the already established curriculum. Drawing, concept mapping, and creativity were encouraged to communicate their ideas, social discussion 
was welcomed as part of the creative process, and ample time as a group or individually were allotted throughout camp to work on portfolios. Adhering to the same qualification as the survey for culturally responsive considerations, the portfolios created by camp participants exhibit eleven of the thirteen suggested Guidelines (Estrin \& Nelson-Barber, 1995) and is considered a compatible assessment strategy per the Handbook (Stephens, 2001).

The portfolios focused on experiences during camp activities, connecting experiences to NGSS NOS concepts through incorporation of "keywords," and relation to which knowledge base. An example how the guidelines for camp participants was expressed:

- Describe three things you learned today using pictures, words, symbols, etc.

- Include keyword(s) in your description.

- Select the knowledge your keyword describes (TEK, science, both, or neither)

Table 8 The modified NGSS NOS Middle School Learning Expectations and the associated keyword for work samples.

Knowledge is cumulative (continually built upon from prior knowledge).

Many people, from many generations and nations, have contributed to our knowledge.

\section{NGSS NOS Understanding}

\section{Keyword}

Past knowledge

Generations

Diverse (people from different nations)

Different sources of knowledge can be used together and benefit one another. Patterns in nature can be observed and measured.

Collaboration

Patterns in nature

Observations

Measurements

Inconsistencies or changes are considered and evaluated.

Changes 
Table 8 Continued

\begin{tabular}{l|c|}
$\begin{array}{l}\text { Men, women and people from different backgrounds engage in building } \\
\text { knowledge. }\end{array}$ & $\begin{array}{c}\text { Diversity (all kinds of } \\
\text { people) }\end{array}$ \\
\hline $\begin{array}{l}\text { Knowledge is based on observation of natural patterns. } \\
\text { Patterns in nature }\end{array}$ \\
$\begin{array}{l}\text { Values like persistence, precision, reasoning, logic, imagination, and creativity } \\
\text { are important. }\end{array}$ & $\begin{array}{c}\text { Creative } \\
\text { Persistence }\end{array}$ \\
\hline $\begin{array}{l}\text { Values like harmony, respect, resiliency, interdependence, and reciprocity } \\
\text { (giving mutually) are important. }\end{array}$ & $\begin{array}{c}\text { Respect } \\
\text { Resiliency } \\
\text { All things are } \\
\text { connected }\end{array}$ \\
\hline $\begin{array}{l}\text { Advances in technology influence the progress of knowledge and knowledge } \\
\text { has influenced advances in technology. }\end{array}$ & Technology \\
\hline
\end{tabular}

The "keywords" were derived from the NGSS NOS understandings (table 10) and were confirmed to be representative of the understandings, although not exclusively. Individual handouts were provided for the youth to reference the specific definition of the keyword when working on portfolios; adherence was varied.

\section{Data: Collection and Analysis}

Survey and portfolio approaches for assessment methods generate a lot of data. For short term analyses (the intent of this research), it provides a snapshot of the impact on NOS understandings in curriculum that is not explicitly targeting those concepts.

\section{Data Collection}

The pre/post surveys were administered during the "orientation" and "wrap-up" portion of each camp, during which other assessments were also being administered: a mathematics (algebra) pre-test (PACE) and a pre-survey regarding higher education and interest in STEM-related topics (Salmon Camp). The NGSS NOS survey (pre/post) took approximately fifteen to thirty minutes for students to complete. 
The portfolios were prompted daily and served as a time to reflect on, share, and analyze the camp activities of each day. For PACE, a daily worksheet was agreed upon and served as entry pages in the youth portfolios. For Salmon Camp, their portfolio was a poster they added entries to everyday. A large poster of the keywords was displayed in the area portfolios were worked on and furthermore, the PACE camp daily worksheet (used for portfolio entry) also displayed a list of the keywords (Appendix B).

It should be noted that although explicit guidance for the use of keywords were explained and demonstrated, unexpected responses or interpretations were not redirected. Only supplemental support was offered when common questions would arise (i.e. "what does TEK mean again?") or observations for the need of TEK vs. tech clarification. This approach may be seen as "hands-off" in formal education, but the intent is to keep camp a safe space for participant expression of their knowledge and experiences, whether or not it was within the expected responses as related to this research, in a certain format, or in some cases even decipherable. The assessment methods, both survey and portfolios were explicitly stated as "without having a right or wrong answer, there may be statements that you agree with and others you do not, and as a survey tool, it is used to see what everyone thinks." The full script for the introduction of this research at camp, for the survey, and portfolio are included in Appendix $\mathrm{H}$.

\section{Data Analyses}

Quantitative and qualitative data are collected through the survey and portfolio assessments. 
NGSS NOS Survey: There are three sections of the survey. Section 1 data consists of engagement in TEK-related practices and activities (i.e. ceremony, hunting, dancing). The number of aspects the youth indicated were totaled; this number is not necessarily reflective of the level of engagement in those activities. Gender data was also collected in Section 1.

Section 2 data consists of the NGSS NOS survey statements and Likert scale responses (strongly disagree to strongly agree). For survey response, the scale for strongly disagree $=1$ and strongly agree $=5$, with negative statements corrected as necessary and strongly disagree $=5$ and strongly agree $=1$. A higher score indicates stronger agreement with NOS statements and understandings. The survey results were analyzed using the Wilcoxon-Signed Ranked Test (Stangroom, 2017). The data for each question was analyzed, comparing the pre and post score for each participant. This tested the null hypothesis to determine if significant differences were prevalent between the pre and post responses. Recall each statement was associated with one or more of the NGSS NOS understandings.

Grouping the survey statements into their respective NGSS NOS overarching concepts (i.e. Science is a way of knowing, Science is a human endeavor) and calculating the average scores allowed for another analysis using the Wilcoxon-Signed Ranked Test (Stangroom, 2017). This analysis will show a more comprehensive picture of the changes in youth understanding of NGSS NOS concepts.

Section 3 data consists of the classification of knowledge (TEK, Western science, both, or neither) for NGSS NOS related statements. Comparing the percent of pre and 
post responses for each statement demonstrates a change in participants classification of knowledge. Also, this data is compared with Section 2 responses regarding the NGSS NOS concepts (i.e. student's may have been in disagreement with "Science is a way of knowing" statements, yet indicated that "science is a way of knowing" is both science and TEK).

Portfolios: The portfolios, although varied in context (daily worksheet vs. poster) contain similar information. Since each portfolio was unique to the participants' experience and responses were not corrected (during or after submissions), not all responses followed the guidelines previously described. In analyzing the portfolios, each entry was scored for each camp participant. Essentially for each entry, the keyword(s) are identified and, the use of the keyword is scored as unrelated to NGSS NOS concept (0), weak demonstration of/relation to NGSS NOS concept (1), and strong demonstration of/relation to NGSS NOS concept (2). Furthermore, the related NGSS NOS concept and characterized knowledge base is recorded. The portfolios were reviewed for common themes and patterns for each day, and for supporting data related to NOS understanding.

Table 9 The scoring rubric for camp participant portfolios.

\begin{tabular}{|c|c|c|c|c|}
\hline Day & Keyword(s) & $\begin{array}{c}\text { Score } \\
(0=\text { unrelated, } \\
1=\text { weak, } 2= \\
\text { strong })\end{array}$ & $\begin{array}{c}\text { NGSS NOS } \\
\text { Concept }\end{array}$ & $\begin{array}{c}\text { Knowledge } \\
\text { Base (TEK, Sci, } \\
\text { Both, Neither) }\end{array}$ \\
\hline$E x: 1$ & $\begin{array}{c}\text { Portfolio entry: "There are four } \\
\text { different types of invasive species. } \\
\text { They made changes in the } \\
\text { invironment by killing the grass } \\
\text { and other plants. They use bugs } \\
\text { or insects to take care of the } \\
\text { invasive plants." }\end{array}$ & 2 & $\begin{array}{c}\text { Scientific } \\
\text { Knowledge } \\
\text { Assumes an Order } \\
\text { and Consistency in } \\
\text { Natural Systems }\end{array}$ & Both \\
\hline
\end{tabular}


Results

The collected data of this this research shows the impact of incorporating traditional ecological knowledge (TEK) into summer science curriculum on middle school student's understanding of the Nature of Science. Data from the Nez Perce Tribe PACE Math and Science Camp (STEM focused) and the Columbia River Inter-Tribal Fish Commission Salmon Camp (TEK-STEM focused) are presented in this section. The data is briefly described and presented in figures describing survey responses and portfolio entries for both PACE and Salmon Camp.

NGSS NOS Survey

The pre/post survey has three sections: demographic and TEK-related engagement, NGSS NOS statements, and knowledge base identification.

Section 1: This section includes data on the home community, gender, and TEK-related engagement for each participant. PACE participants were all from communities on or nearby the Nez Perce Reservation $(n=22)$. Salmon Camp participants $(n=14)$ were from communities on or nearby the reservations of the four CRITFC tribes: (Umatilla ( $n$ =2), Warm Springs $(n=2)$, Yakama $(n=4)$, and Nez Perce $(n=3))$ and three participants from the Portland metropolitan area. For PACE there were thirteen male participants and nine female participants. For Salmon Camp there were six male participants and eight female participants. The number of TEK-related engagements by camp participants ranged between $1-11$, with fishing and gathering berries showing the highest levels of engagement (most PACE participants and all Salmon Camp 
participants). The table below shows the distribution of this data for each camp (percent of participants declaring TEK-related engagements):

Figure 5 TEK-related engagements as declared by camp participants.

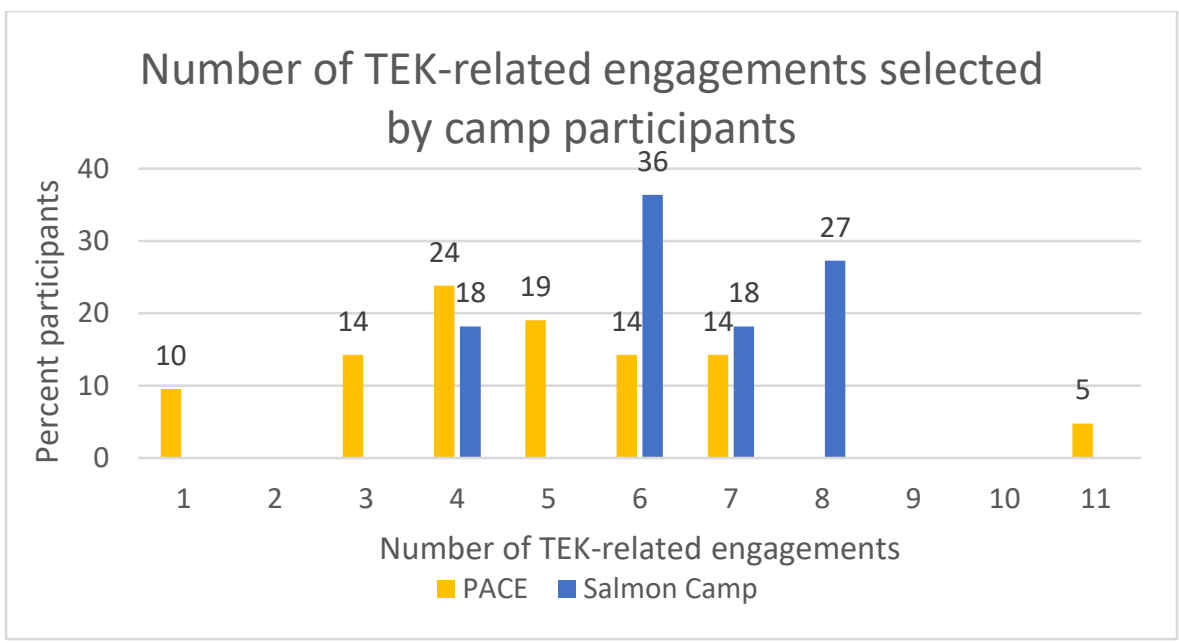

Section 2: This section is comprised of Likert scale responses to NGSS NOS statements. The negative statements in the survey (\#2, \#4, \#11,\#12) were corrected to reflect the applied scoring scale ( 1 = strongly disagree, $5=$ strongly agree $)$. Responses exhibiting the ceiling effect were removed, and responses with no answer or undecipherable responses were also removed. Higher scores indicate stronger agreement with the NGSS NOS survey statements. Changes in scores between pre and post surveys are compared. When comparing camps, percentages are used to account for the difference in amount of camp participants.

A survey response of "disagree" or "strongly disagree" is considered disagreement of the survey statement; Similarly, "agree" or "strongly agree" is considered agreement of the statement. Responses were compiled for either disagreement (D), neutral (N), or agreement (A) with the survey statements for an overview of the data. The percent of 
responses for each category $(\mathrm{D}, \mathrm{N}, \mathrm{A})$ for pre and post surveys are summarized below for each camp:

Figure 6 Overall pre/post survey responses for each camp.
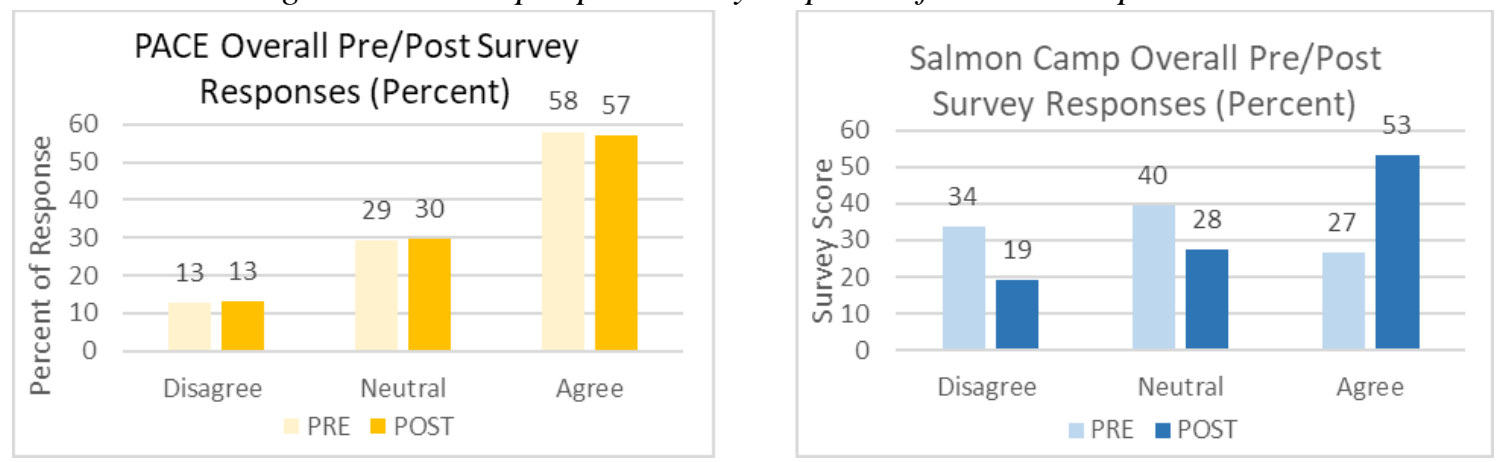

PACE Camp overall responses had essentially no change between pre and post surveys

(i.e. $13 \%$ of the overall responses disagreed with the statements for both the pre and post survey). For Salmon Camp, there was a $26 \%$ increase in overall responses for agreement with statements. The post survey responses for agreement to statements for PACE (57\%) and Salmon Camp (53\%) are comparable, although the Salmon Camp pre survey responses for agreement were $27 \%$.

Further comparing the pre and post responses, the percent change of total disagreement, neutral, and agreement responses were calculated for each statement. Below the percent change of agreement responses for each statement are shown as overall data from both PACE and Salmon Camp. This shows the distribution of the change in responses for each statement (i.e. For statement 1, The agreement responses decreased by $2 \%$ for PACE, while Salmon Camp agreement responses increased by 10\%). Statements $1-9$ have the highest increase in percent agreement for Salmon Camp responses, while only statements 5, 7, 9, and 14 show increase in percent agreement for PACE responses. The data demonstrates that agreement responses are not equally distributed across all survey 
statements. Each survey statement is further considered individually, from which further evaluation of the NGSS NOS concepts can be considered.

Figure 7 The change in survey responses for each statement for both PACE and Salmon Camp.

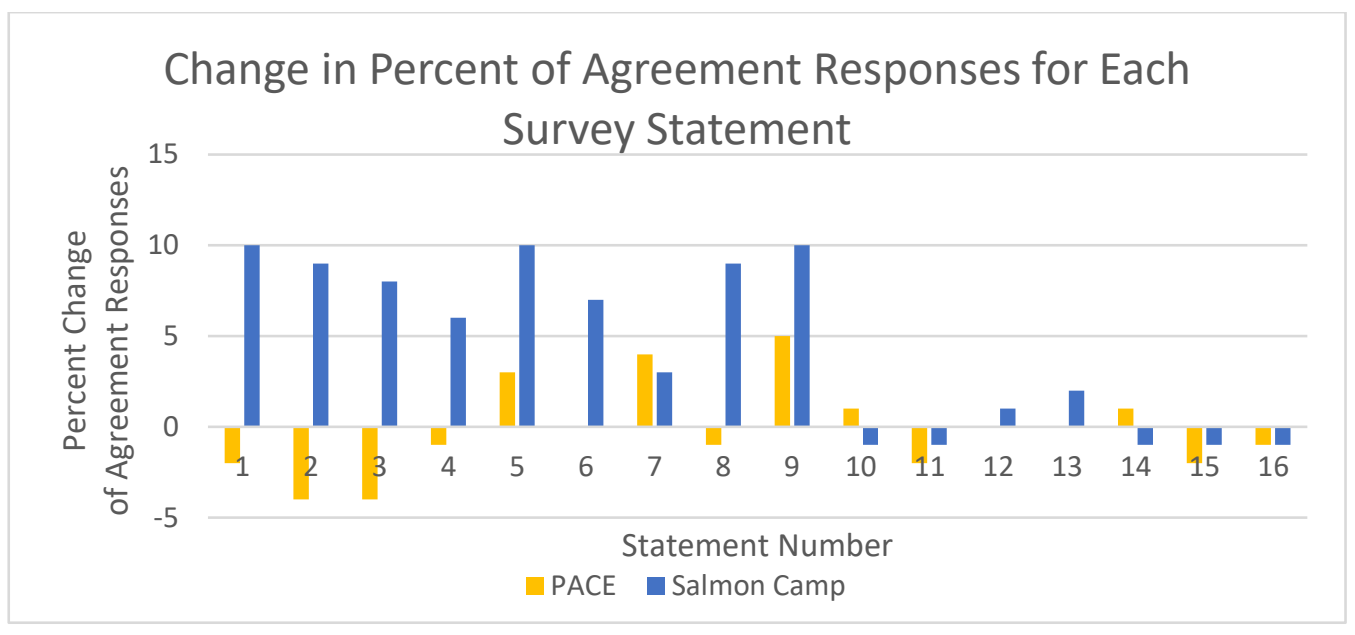

Another approach to survey data is to examine the change in overall pre/post scores. The change was evaluated between overall pre and post scores for each camp participant were categorized into negative change, neutral/no change, and a positive change of $1-5$ points, $6-10$ points, and greater than ten points. Thirteen of the fourteen Salmon Camp surveys increased by six or more points, while twelve of the PACE surveys had negative change in their overall survey score. Salmon Camp participants showed greater increase in survey scores when compared to PACE participants. The percent of camp participants for each category are summarized below for each camp: 
Figure 8 The overall change in survey scores displayed by negative change, no change, and increases of 1-5 points, 6-10 points, and more than 10 points.

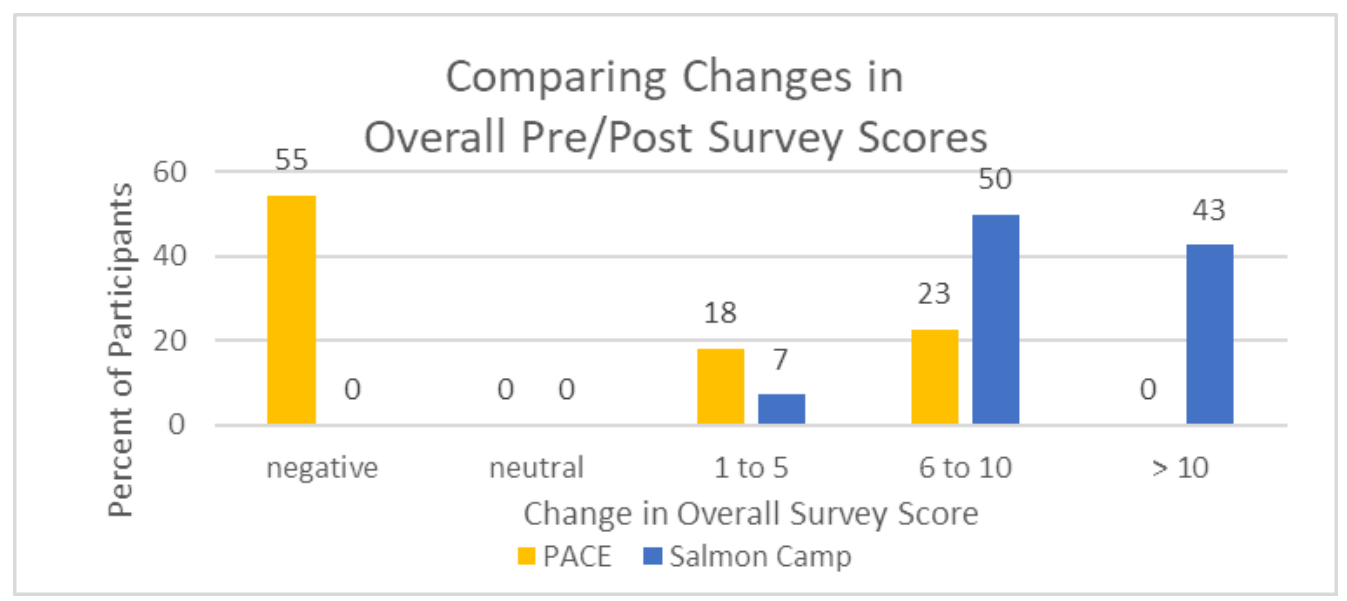

The survey responses for each question was analyzed, comparing the pre and post score for each participant results using the Wilcoxon-Signed Ranked Test (Stangroom, 2017). The following figures and tables show the Wilcoxon-Signed Ranked Test analysis and the change in Likert scale responses for each statement. Percent of participants is used to compare data for PACE and Salmon Camp.

Statement 1: Science is built upon years of knowledge.

The Wilcoxon-Signed Ranked Test statistical analysis indicates there were no significant changes (at $\mathrm{p} \leq 0.05$ ) for PACE responses and a significant positive change for Salmon Camp responses $(\mathrm{p}=0.00148)$. Figure shows a positive shift in participant responses for Salmon Camp, while PACE does not exhibit a measurable shift. The PACE responses had $68 \%$ no change, while $47 \%$ of Salmon Camp responses increased by one point and $40 \%$ increased by two or more points. No changes for either camp were below a -1 . 
Figure 9 Result details for survey statement "science is built upon years of knowledge."

Result Details: Science is built upon years of knowledge.

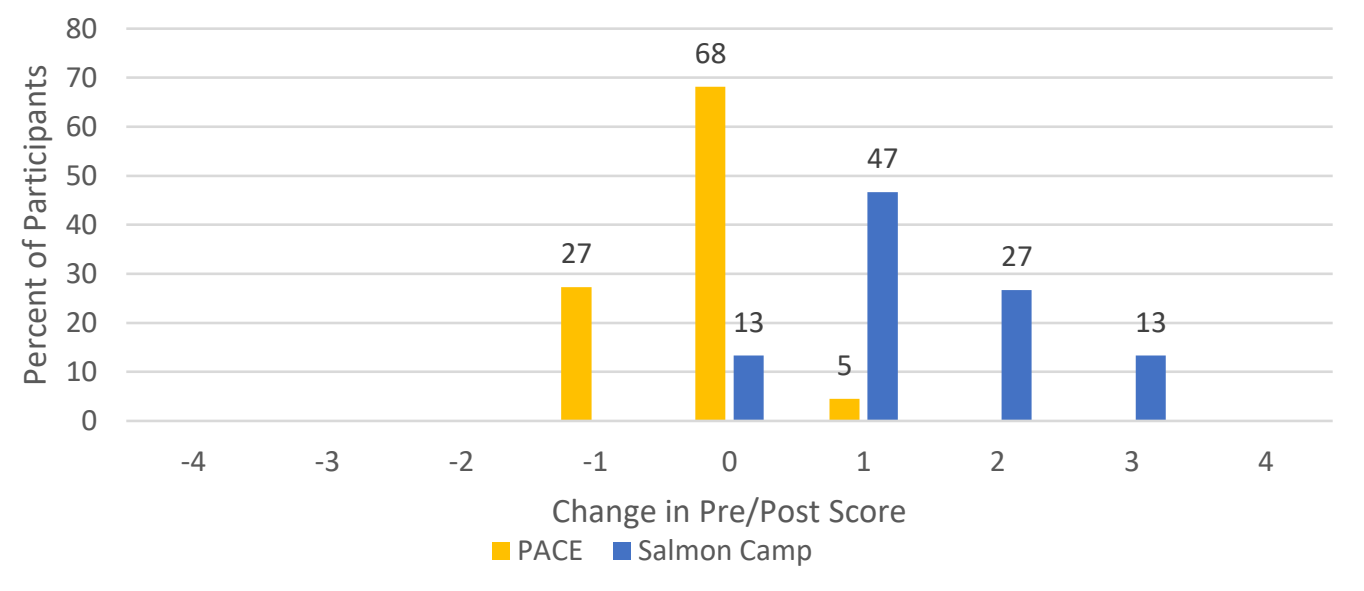

\begin{tabular}{|l|r|r|}
\hline \multicolumn{2}{|c|}{ Result Details: Science is built upon years of knowledge. } \\
\hline & \multicolumn{1}{|c|}{ PACE Camp } & Salmon Camp \\
\hline W-value: & 4 & 0 \\
Mean Difference: & 0.43 & -2 \\
Sum of pos. ranks: & 24 & 0 \\
Sum of neg. ranks: & 4 & 91 \\
& & \\
Z-value: & -1.6903 & -3.1798 \\
Mean (W): & (N too small) & 45.5 \\
Standard Deviation (W): & & 14.31 \\
P-value (P $\leq 0.05)$ & & 0.00148 \\
& & 13 \\
Sample size (N): & 7 & 0 \\
Ceiling: & 2 & \\
\hline
\end{tabular}

Statement 2: Science is a solitary pursuit (done alone).

The Wilcoxon-Signed Ranked Test statistical analysis indicates there were no significant changes (at $\mathrm{p} \leq 0.05$ ) for PACE responses and a significant positive change for Salmon Camp responses $(p=0.00148)$. Figure 7 shows a positive shift in participant responses for Salmon Camp, while PACE does not exhibit a measurable shift. PACE responses were $45 \%$ unchanged, with $32 \%$ increasing by one point. Salmon Camp responses were 
$27 \%$ unchanged, with $20 \%$ increases by one and two points. No changes in either camp were below -2 .

Figure 10 Result details for survey statement "Science is a solitary pursuit (done alone)."

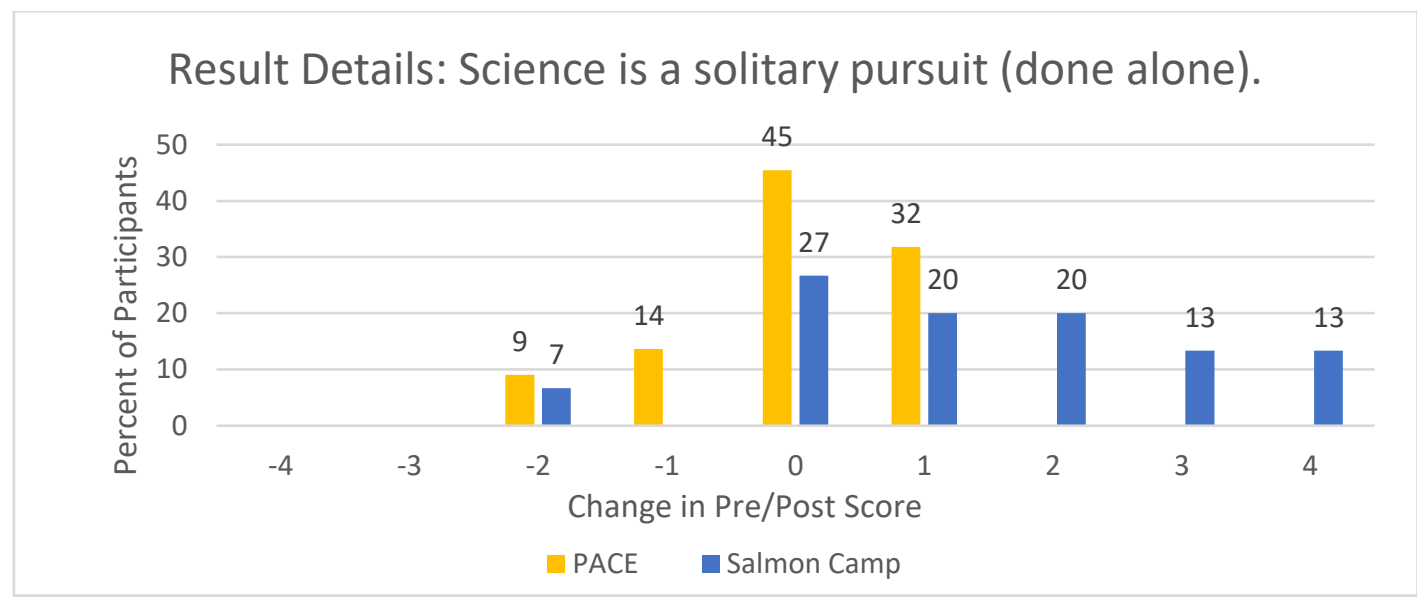

\begin{tabular}{|l|r|r|}
\hline \multicolumn{2}{|c|}{ Result Details: Science is a solitary pursuit (done alone). } \\
\hline & PACE Camp & Salmon Camp \\
\hline W-value: & 38.5 & 5.5 \\
Mean Difference: & 1.08 & -2 \\
Sum of pos. ranks: & 39.5 & 0 \\
Sum of neg. ranks: & 38.5 & 91 \\
& & \\
Z-value: & -0.0392 & -3.1798 \\
Mean (W): & 39 & 45.5 \\
Standard Deviation (W): & 12.75 & 14.31 \\
P-value (P $\leq 0.05)$ & 0.9681 & 0.00148 \\
& & \\
Sample size (N): & 12 & 13 \\
Ceiling: & 1 & 0 \\
\hline
\end{tabular}

Statement 3: Citizens use science every day.

The Wilcoxon-Signed Ranked Test statistical analysis indicates there were no significant changes (at $p \leq 0.05$ ) for PACE responses and a significant positive change for Salmon Camp responses $(\mathrm{p}=0.00512)$. Figure 8 shows a positive shift in participant responses for Salmon Camp, while PACE does not exhibit a measurable shift. Responses for PACE 
$43 \%$ unchanged with $33 \%$ being a decrease in one or two points. Salmon Camp responses were $20 \%$ unchanged, and $47 \%$ with a two point increase. No changes were below -2 .

Figure 11 Result details for survey statement "Citizens use science every day."

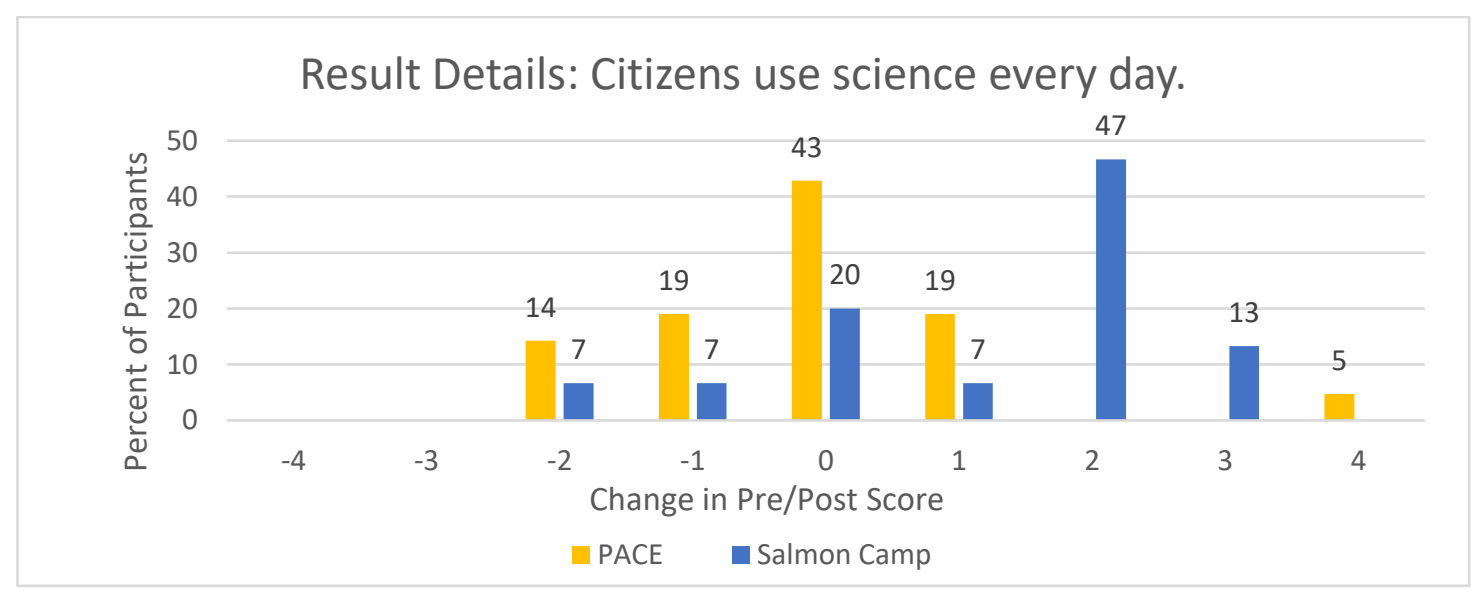

\begin{tabular}{|l|r|r|}
\hline \multicolumn{2}{|c|}{ Result Details: Citizens use science every day. } \\
\hline W-value: & PACE Camp & Salmon Camp \\
Mean Difference: & 30 & 1.5 \\
Sum of pos. ranks: & -0.92 & -2.18 \\
Sum of neg. ranks: & 61 & 1.5 \\
& 30 & 64.5 \\
Z-value: & -1.0832 & -2.8007 \\
Mean (W): & 45.4 & 33 \\
Standard Deviation (W): & 14.31 & 11.25 \\
P-value (P $\leq 0.05)$ & 0.28014 & 0.00512 \\
& & 11 \\
Sample size (N): & 13 & 0 \\
Ceiling: & 1 & \\
\hline
\end{tabular}

Statement 4: Observations by citizens do not contribute to scientific knowledge.

The Wilcoxon-Signed Ranked Test statistical analysis indicates there were no significant changes (at $\mathrm{p} \leq 0.05)$ for PACE responses and a significant positive change for Salmon Camp responses $(\mathrm{p}=0.00222)$. Figure 9 shows a positive shift in participant responses 
for Salmon Camp, while PACE does not exhibit a measurable shift. Response for PACE were $71 \%$ unchanged, while Salmon Camp responses increased by one point for $53 \%$ of participants and two points for $20 \%$ of participants. No changes were below -2 .

Figure 12 Result details for survey statement "Observations by citizens do not contribute to scientific knowledge."

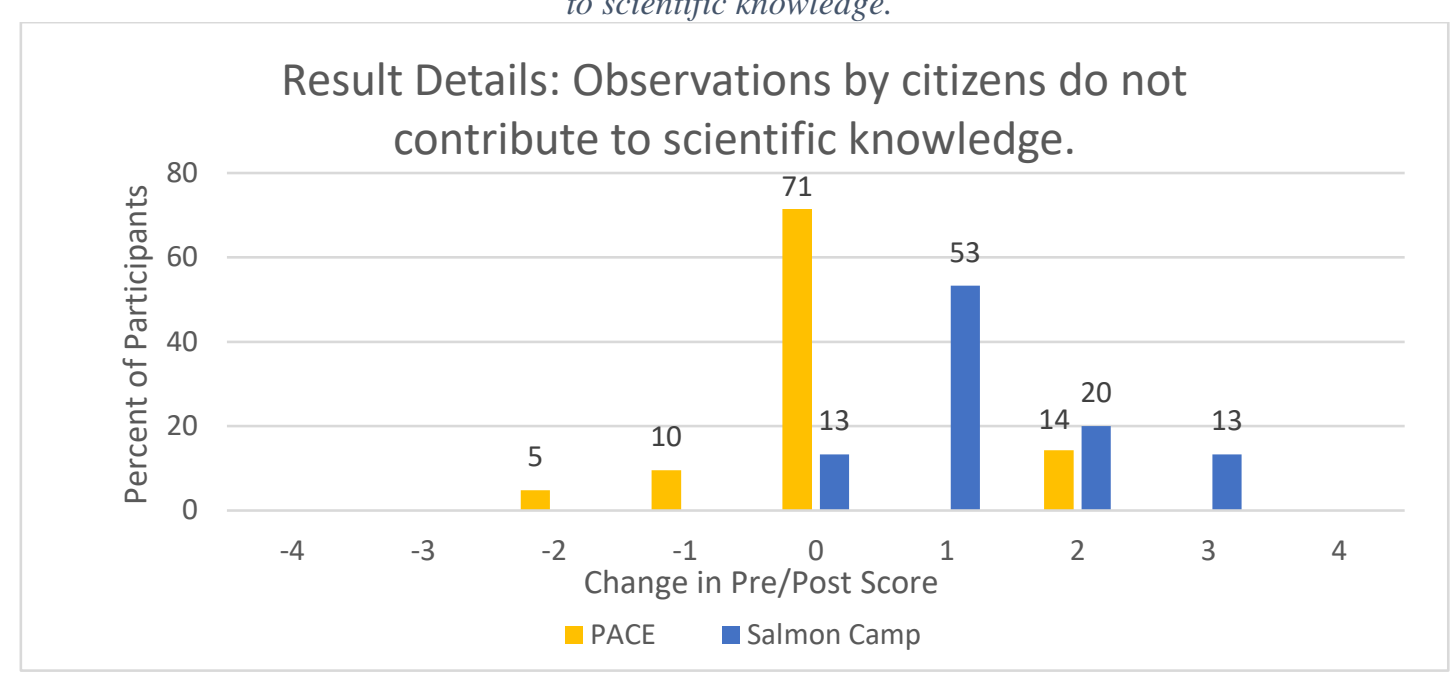

\begin{tabular}{|c|c|c|}
\hline \multicolumn{3}{|c|}{ Result Details: Observations by citizens do not contribute to scientific knowledge. } \\
\hline & PACE Camp & Salmon Camp \\
\hline W-value: & 13.5 & 0 \\
\hline Mean Difference: & 1.29 & -2.17 \\
\hline Sum of pos. ranks: & 14.5 & 0 \\
\hline Sum of neg. ranks: & 13.5 & 78 \\
\hline Z-value: & -0.0845 & -3.0594 \\
\hline Mean (W): & (N too small) & 39 \\
\hline Standard Deviation $(\mathrm{W})$ : & & 12.75 \\
\hline $\mathrm{P}$-value $(\mathrm{P} \leq 0.05)$ & & 0.00222 \\
\hline Sample size $(\mathrm{N})$ : & 7 & 12 \\
\hline Ceiling: & 1 & 0 \\
\hline
\end{tabular}

Statement 5: Science can study things and events that happened in the past, even if no one was there to observe it.

The Wilcoxon-Signed Ranked Test statistical analysis indicates there were no significant changes (at $\mathrm{p} \leq 0.05)$ for PACE responses and a significant positive change for Salmon 
Camp responses $(\mathrm{p}=0.0048)$. Figure 10 shows a positive shift in participant responses for Salmon Camp, while PACE does not exhibit a measurable shift. Responses for PACE were 55\% unchanged. Salmon Camp responses had a two point gain for 33\% of participants and $27 \%$ with one point gain. Lowest changes for PACE was -2 , and -3 for

\section{Salmon Camp.}

Figure 13 Result details for survey statement "Science can study things and events that happened in the past,even if no one was there to observe it."

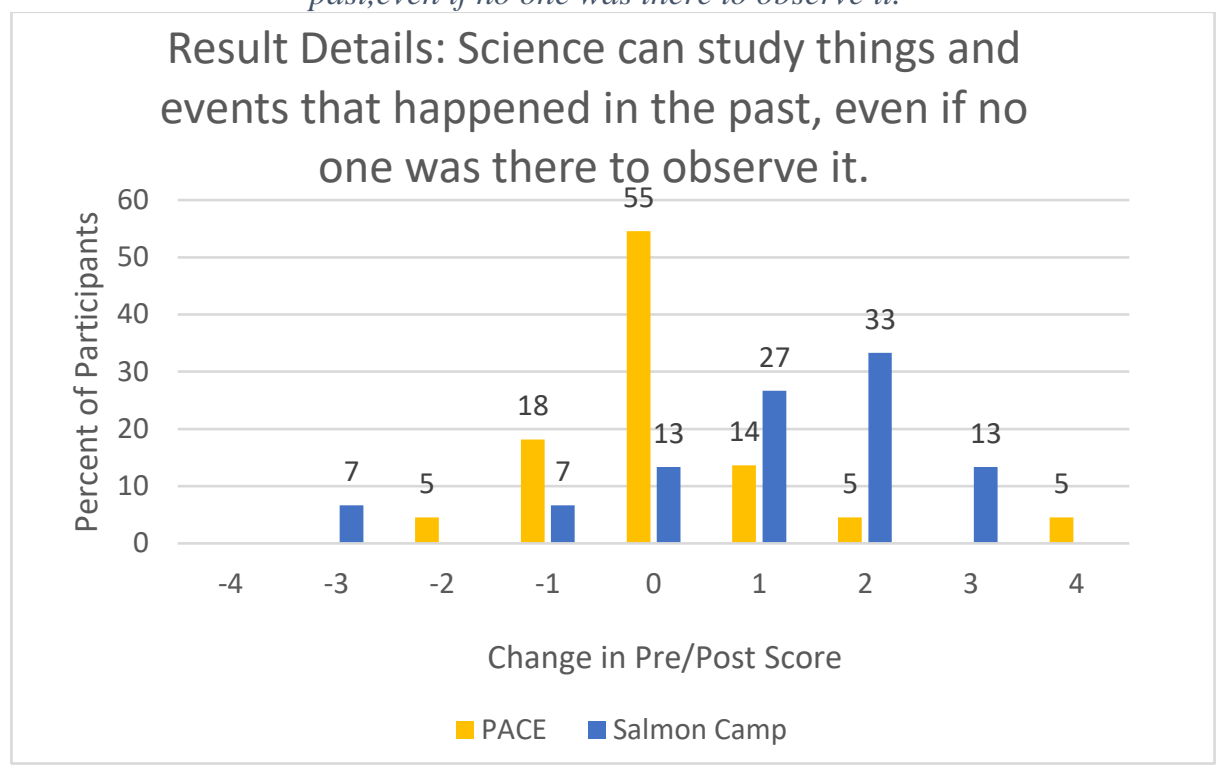

\begin{tabular}{|l|r|r|}
\hline \multicolumn{2}{|c|}{$\begin{array}{c}\text { Result Details: Science can study things and events that happened in the } \\
\text { past, even if no one was there to observe it. }\end{array}$} \\
\hline & PACE Camp & Salmon Camp \\
\hline W-value: & 24.5 & 3 \\
Mean Difference: & -0.6 & -0.58 \\
Sum of pos. ranks: & 24.5 & 3 \\
Sum of neg. ranks: & 30.5 & 75 \\
& & \\
Z-value: & -0.3058 & -2.8241 \\
Mean (W): & 27.5 & 39 \\
Standard Deviation (W): & 9.81 & 12.75 \\
P-value (P $\leq 0.05)$ & 0.75656 & 0.0048 \\
& & \\
Sample size (N): & 10 & 12 \\
Ceiling: & 1 & 0 \\
\hline
\end{tabular}


Statement 6: Science is based on observation of natural patterns.

The Wilcoxon-Signed Ranked Test statistical analysis indicates there were no significant changes (at $\mathrm{p} \leq 0.05$ ) for PACE responses and a significant positive change for Salmon Camp responses $(\mathrm{p}=0.02088)$. Figure 11 shows a positive shift in participant responses for Salmon Camp, while PACE does not exhibit a measurable shift. Responses for PACE were 52\% unchanged and 19\% exhibited changes of both -1 and +1 . Salmon Camp responses had a one point gain for 33\% of participants, $20 \%$ with no change, and $20 \%$ with a three point gain. No changes were below -2 .

Figure 14 Result details for survey statement "Science is based on observation of natural patterns."

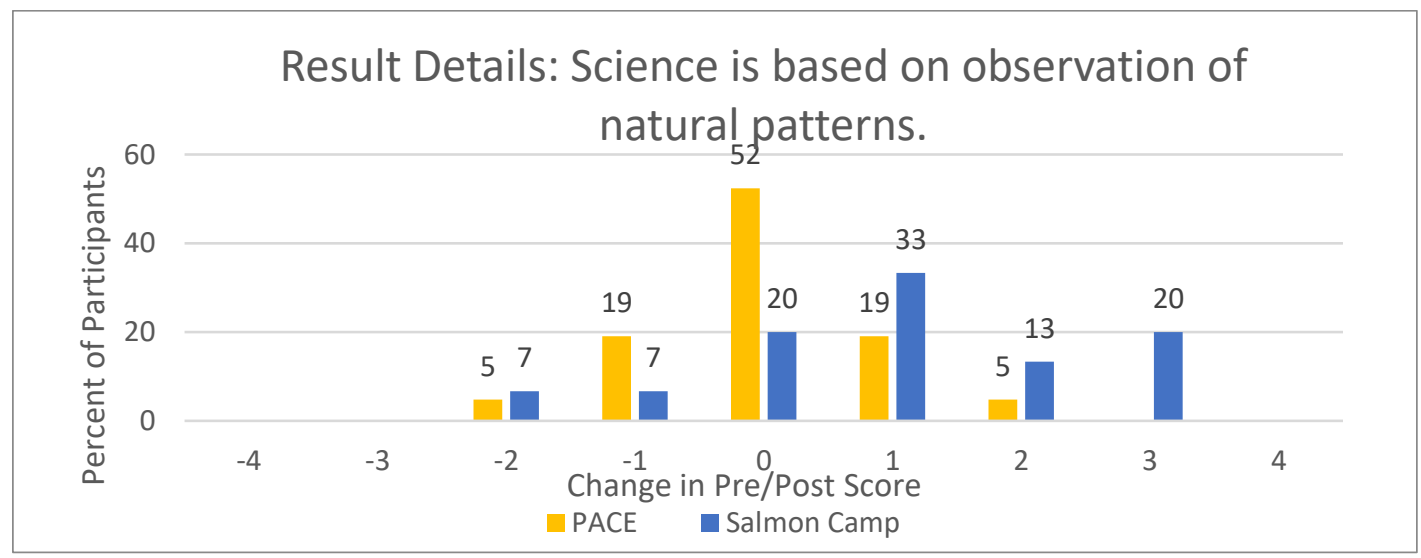

\begin{tabular}{|l|r|r|}
\hline \multicolumn{2}{|c|}{ Result Details: Observations by citizens do not contribute to } \\
scientific knowledge.
\end{tabular}


Statement 7: We accept an idea as scientific knowledge only if it doesn't have any errors.

The Wilcoxon-Signed Ranked Test statistical analysis indicates there were no significant changes $($ at $p \leq 0.05)$ for PACE and Salmon Camp responses. Figure 12 shows no shift for either camp. Responses for PACE were $45 \%$ unchanged and $32 \%$ exhibited a one point gain. Salmon Camp responses had a one point gain for $40 \%$ of participants, yet $27 \%$ decreased by two points. No changes were below -2 .

Figure 15 Result details for survey statement "We accept an idea as scientific knowledge only if it doesn't have any errors."

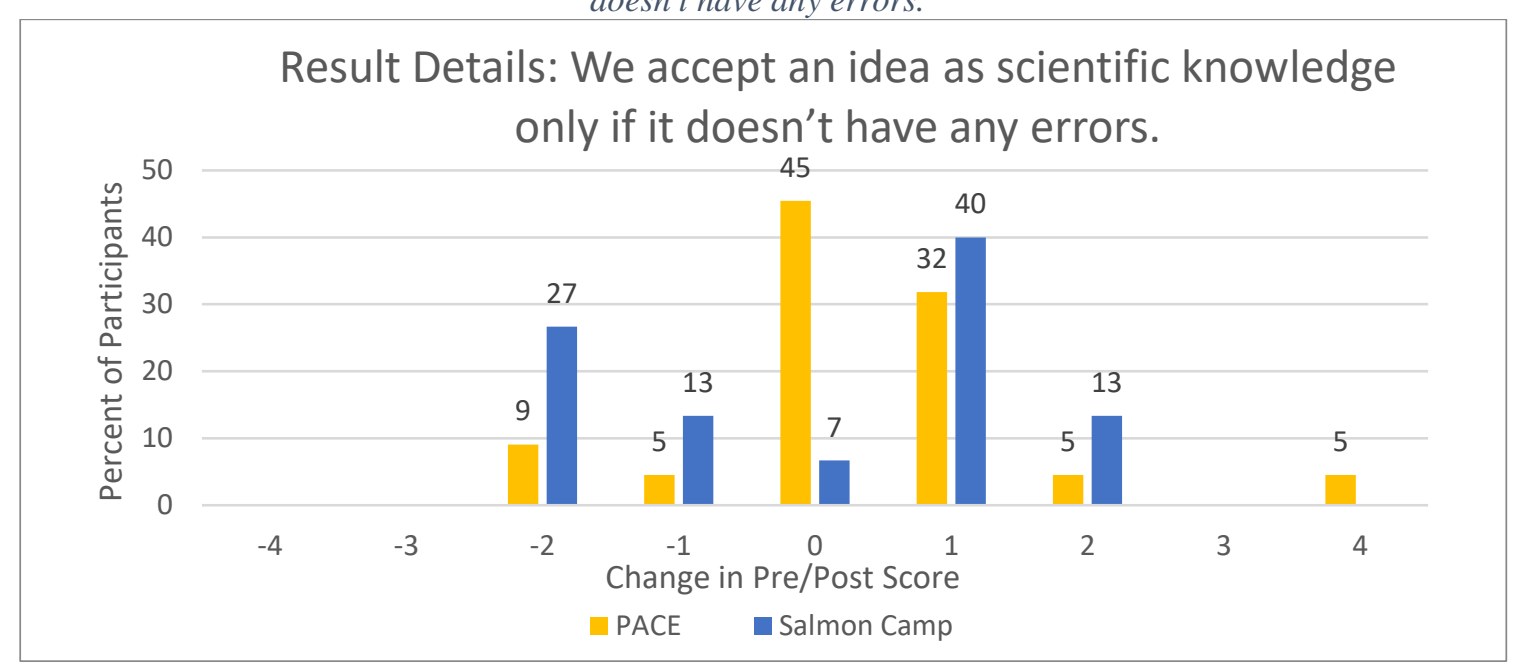

\begin{tabular}{|l|r|r|}
\hline \multicolumn{3}{|c|}{$\begin{array}{c}\text { Result Details: We accept an idea as scientific knowledge only if it } \\
\text { doesn't have any errors. }\end{array}$} \\
\hline & PACE Camp & Salmon Camp \\
\hline W-value: & 24.5 & 50 \\
Mean Difference: & 1.58 & 0.5 \\
Sum of pos. ranks: & 24.5 & 55 \\
Sum of neg. ranks: & 53.5 & 50 \\
& & \\
Z-value: & -1.1375 & -0.1569 \\
Mean (W): & 39 & 52.5 \\
Standard Deviation (W): & 12.75 & 15.93 \\
P-value (P $\leq 0.05)$ & 0.25428 & 0.87288 \\
& & 14 \\
Sample size (N): & 12 & 0 \\
Ceiling: & 0 & \\
\hline
\end{tabular}


Statement 8: Science data can be interpreted in new ways.

The Wilcoxon-Signed Ranked Test statistical analysis indicates there were no significant changes (at $\mathrm{p} \leq 0.05$ ) for PACE responses and a significant positive change for Salmon Camp responses $(\mathrm{p}=0.00236)$. Figure 13 shows a positive shift in participant responses for Salmon Camp, while PACE does not exhibit a measurable shift. Responses for PACE were 45\% unchanged and $23 \%$ exhibited changes of both -1 and +1 . Salmon Camp responses had a one point gain for $40 \%$ of participants and $47 \%$ with a two point o or more point increase. No changes were below -2 .

Figure 16 Result details for survey statement "Science data can be interpreted in new way."

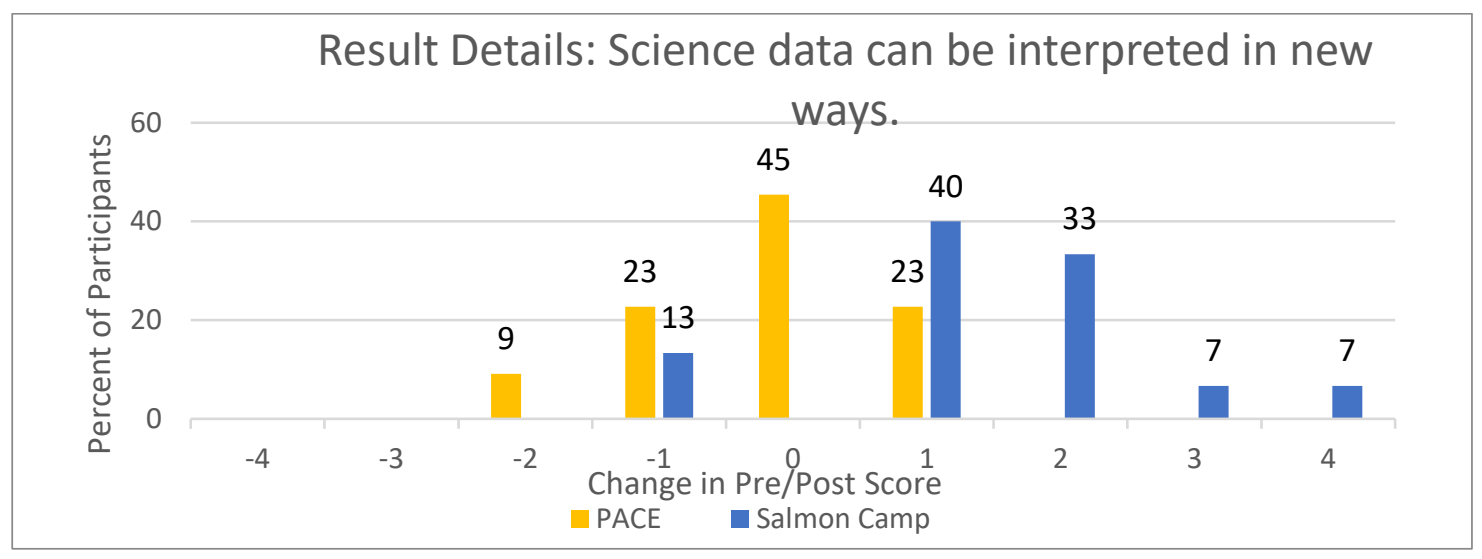

\begin{tabular}{|l|r|r|}
\hline \multicolumn{2}{|c|}{ Result Details: Science data can be interpreted in new ways. } \\
\hline & PACE Camp & Salmon Camp \\
\hline W-value: & 27.5 & 4 \\
Mean Difference: & 1.5 & -1.36 \\
Sum of pos. ranks: & 50.5 & 4 \\
Sum of neg. ranks: & 27.5 & 101 \\
\hline & & \\
Z-value: & -0.9021 & -3.0447 \\
Mean (W): & 39 & 52.5 \\
Standard Deviation (W): & 12.75 & 15.93 \\
P-value (P $\leq 0.05)$ & 0.36812 & 0.00236 \\
& & \\
Sample size (N): & 12 & 14 \\
Ceiling: & 1 & 0 \\
\hline
\end{tabular}


Statement 9: Anyone can be a scientist.

The Wilcoxon-Signed Ranked Test statistical analysis indicates there were no significant changes (at $\mathrm{p} \leq 0.05$ ) for PACE responses and a significant positive change for Salmon Camp responses $(\mathrm{p}=0.00328)$. Figure 14 shows a positive shift in participant responses for Salmon Camp, while PACE does not exhibit a measurable shift. Responses for PACE were 50\% unchanged. Salmon Camp responses had an increase of three points for $40 \%$ of the participants. For PACE a -3 was the lowest response, and -2 for Salmon Camp.

Figure 17 Result details for survey statement "Anyone can be a scientist."

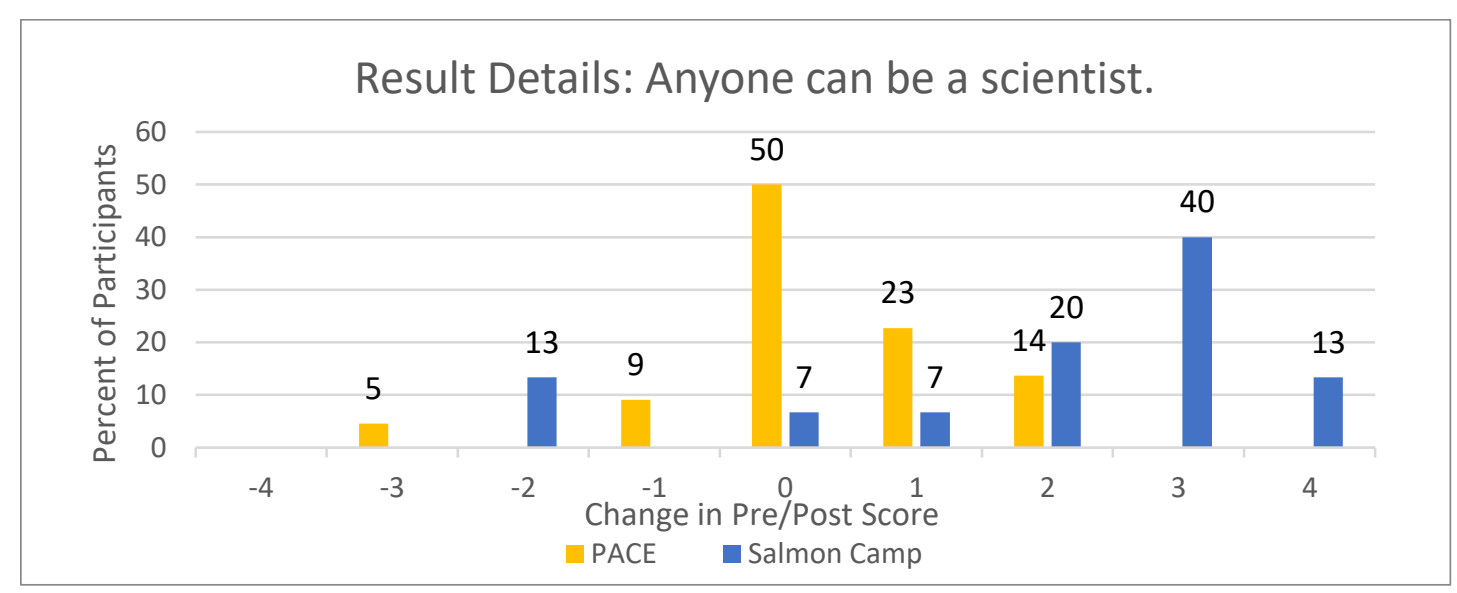

\begin{tabular}{|l|r|r|}
\hline \multicolumn{3}{|c|}{ Result Details: Anyone can be a scientist. } \\
\hline & PACE Camp & Salmon Camp \\
\hline W-value: & 19 & 3.5 \\
Mean Difference: & -0.73 & -3.23 \\
Sum of pos. ranks: & 19 & 3.5 \\
Sum of neg. ranks: & 47 & 87.5 \\
& & \\
Z-value: & -1.2448 & -2.9352 \\
Mean (W): & 33 & 45.5 \\
Standard Deviation (W): & 11.25 & 14.31 \\
P-value (P $\leq 0.05)$ & 0.21498 & 0.00328 \\
& & \\
Sample size (N): & 11 & 13 \\
Ceiling: & 4 & 0 \\
\hline
\end{tabular}


Statement 10: People from all over the world contribute to science knowledge.

The Wilcoxon-Signed Ranked Test statistical analysis indicates there were no significant changes $($ at $\mathrm{p} \leq 0.05)$ for PACE or Salmon Camp responses. Figure 15 shows no shift for either camp. Responses for PACE were 55\% unchanged. Salmon Camp responses were split three ways between positive, no change, and negative change in points. For PACE a -1 was the lowest response, and -4 for Salmon Camp.

Figure 18 Result details for survey statement "People from all over the world contribute to science knowledge."

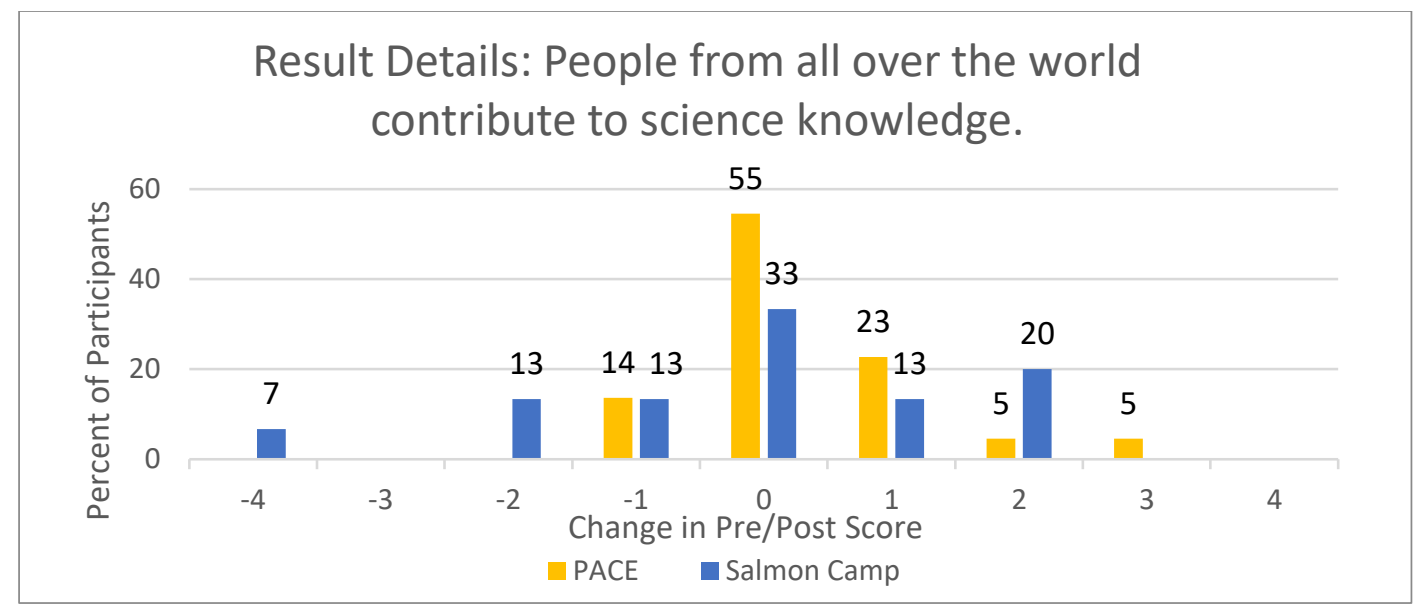

\begin{tabular}{|l|r|r|}
\hline \multicolumn{2}{|c|}{ Result Details: People from all over the world contribute to science } \\
knowledge.
\end{tabular}


Statement 11: Scientists rarely use creativity.

The Wilcoxon-Signed Ranked Test statistical analysis indicates there were no significant changes $($ at $\mathrm{p} \leq 0.05)$ for PACE or Salmon Camp responses. Figure 16 shows no shift for either camp. Responses for PACE were $62 \%$ unchanged. Salmon Camp responses with no change, -1 , and -2 comprised $20 \%$ of participant responses each. For PACE a two point decrease was the lowest response, and a three point decrease for

\section{Salmon Camp.}

Figure 19 Result details for survey statement "Scientists rarely use creativity."

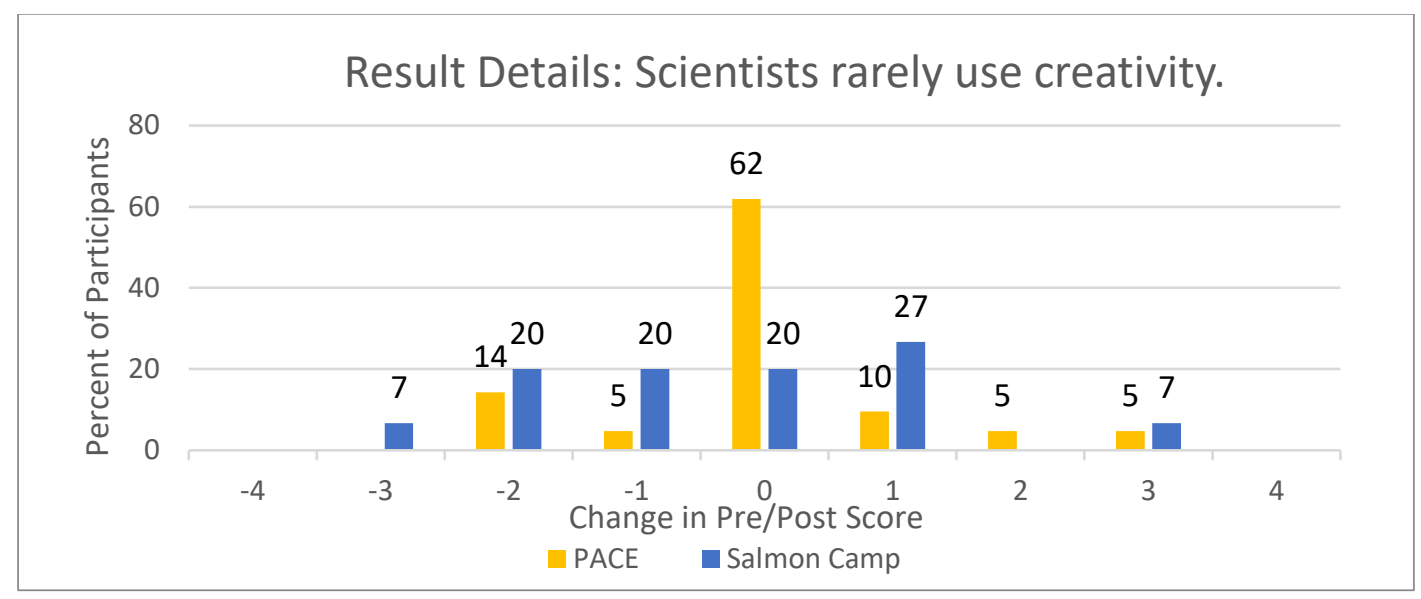

\begin{tabular}{|c|c|c|}
\hline \multicolumn{3}{|c|}{ Result Details: People from all over the world contribute to science knowledge. } \\
\hline & PACE Camp & Salmon Camp \\
\hline W-value: & 17.5 & 26.5 \\
\hline Mean Difference: & -1.22 & -0.26 \\
\hline Sum of pos. ranks: & 27.5 & 39.5 \\
\hline Sum of neg. ranks: & 17.5 & 26.5 \\
\hline Z-value: & -0.5923 & -0.5779 \\
\hline Mean $(W)$ : & (N too small) & 33 \\
\hline Standard Deviation (W): & & 11.25 \\
\hline $\mathrm{P}$-value $(\mathrm{P} \leq 0.05)$ & & 0.56192 \\
\hline Sample size $(\mathrm{N})$ : & 9 & 11 \\
\hline Ceiling: & 2 & 0 \\
\hline
\end{tabular}


Statement 12: Disagreement between scientists is one of the weaknesses of science.

The Wilcoxon-Signed Ranked Test statistical analysis indicates there were no significant changes $($ at $\mathrm{p} \leq 0.05)$ for PACE or Salmon Camp responses. Figure 17 shows no shift for either camp. Unchanged responses resulted from $45 \%$ of PACE participants and $40 \%$ of Salmon Camp participants. For both camps, a two-point decrease was observed.

Figure 20 Result details for survey statement "Disagreement between scientists is one of the weaknesses of science."

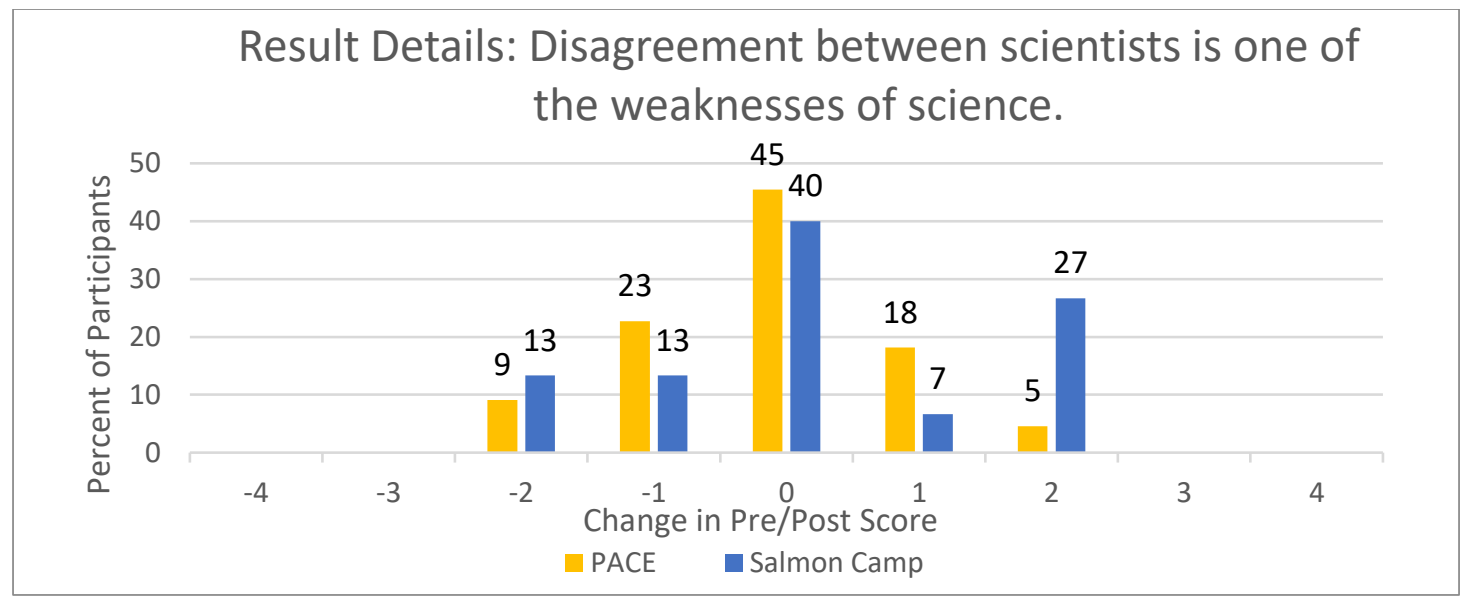

\begin{tabular}{|l|r|r|}
\hline \multicolumn{3}{|c|}{ Result Details: Disagreement between scientists is one of the weaknesses of science. } \\
\hline & PACE Camp & \multicolumn{1}{|c|}{ Salmon Camp } \\
\hline W-value: & 31 & 14 \\
Mean Difference: & -2.42 & 0.62 \\
Sum of pos. ranks: & 47 & 14 \\
Sum of neg. ranks: & 31 & 22 \\
& \multicolumn{3}{|c|}{} \\
Z-value: & -0.6276 & -0.5601 \\
Mean (W): & 39 & (N too small) \\
Standard Deviation (W): & 12.75 & \\
P-value (P $\leq 0.05)$ & 0.5287 & \\
& & 12 \\
Sample size (N): & 0 & 0 \\
Ceiling: & \multicolumn{2}{|c|}{} \\
\hline
\end{tabular}


Statement 13: Advances in technology influence the progress of science.

The Wilcoxon-Signed Ranked Test statistical analysis indicates there were no significant changes (at $\mathrm{p} \leq 0.05$ ) for PACE or Salmon Camp responses. Figure 18 shows no shift for either camp. PACE responses were $38 \%$ unchanged. Forty percent of Salmon Camp responses increased by one point, while $20 \%$ were unchanged. For PACE a maximum decrease of two points was observed, while -4 was observed for Salmon Camp (one response).

Figure 21 Result details for survey statement "Advances in technology influence the progress of science."

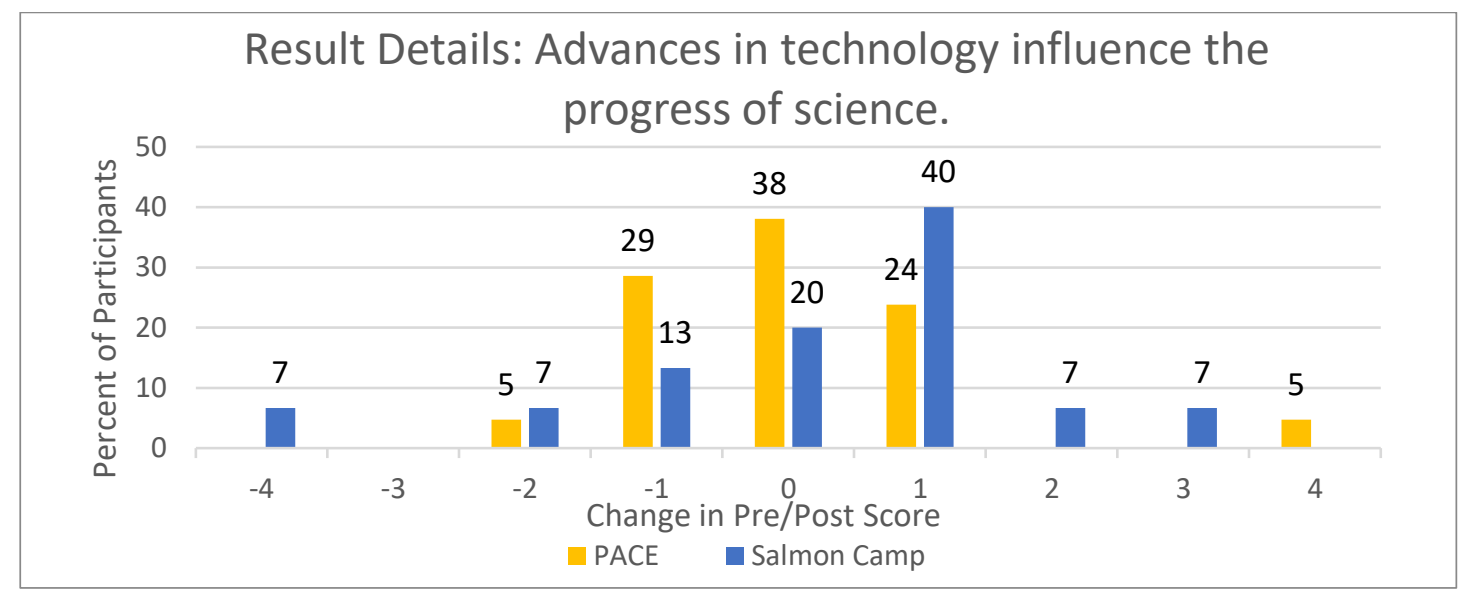

\begin{tabular}{|c|c|c|}
\hline \multicolumn{3}{|c|}{ Result Details: Advances in technology influence the progress of science. } \\
\hline & PACE Camp & Salmon Camp \\
\hline W-value: & 43 & 18.5 \\
\hline Mean Difference: & 1.29 & -1.91 \\
\hline Sum of pos. ranks: & 62 & 18.5 \\
\hline Sum of neg. ranks: & 43 & 47.5 \\
\hline Z-value: & -0.5964 & -1.2892 \\
\hline Mean $(\mathrm{W})$ : & 52.5 & 33 \\
\hline Standard Deviation $(\mathrm{W})$ : & 15.93 & 11.25 \\
\hline $\mathrm{P}$-value $(\mathrm{P} \leq 0.05)$ & 0.5485 & 0.19706 \\
\hline Sample size $(\mathrm{N})$ : & 14 & 11 \\
\hline Ceiling: & 0 & 0 \\
\hline
\end{tabular}


Statement 14: Science is limited by human capacity and technology.

The Wilcoxon-Signed Ranked Test statistical analysis indicates there were no significant changes (at $\mathrm{p} \leq 0.05$ ) for PACE or Salmon Camp responses. Figure 19 shows no shift for either camp. PACE responses were $32 \%$ unchanged, $32 \%$ one point increase, and 23\% one point decrease. Salmon Camp had 27\% of responses increase and decrease by one point each. The lowest observed change in responses for both camps was -3 .

Figure 22 Result details for survey statement "Science is limited by human capacity and technology."

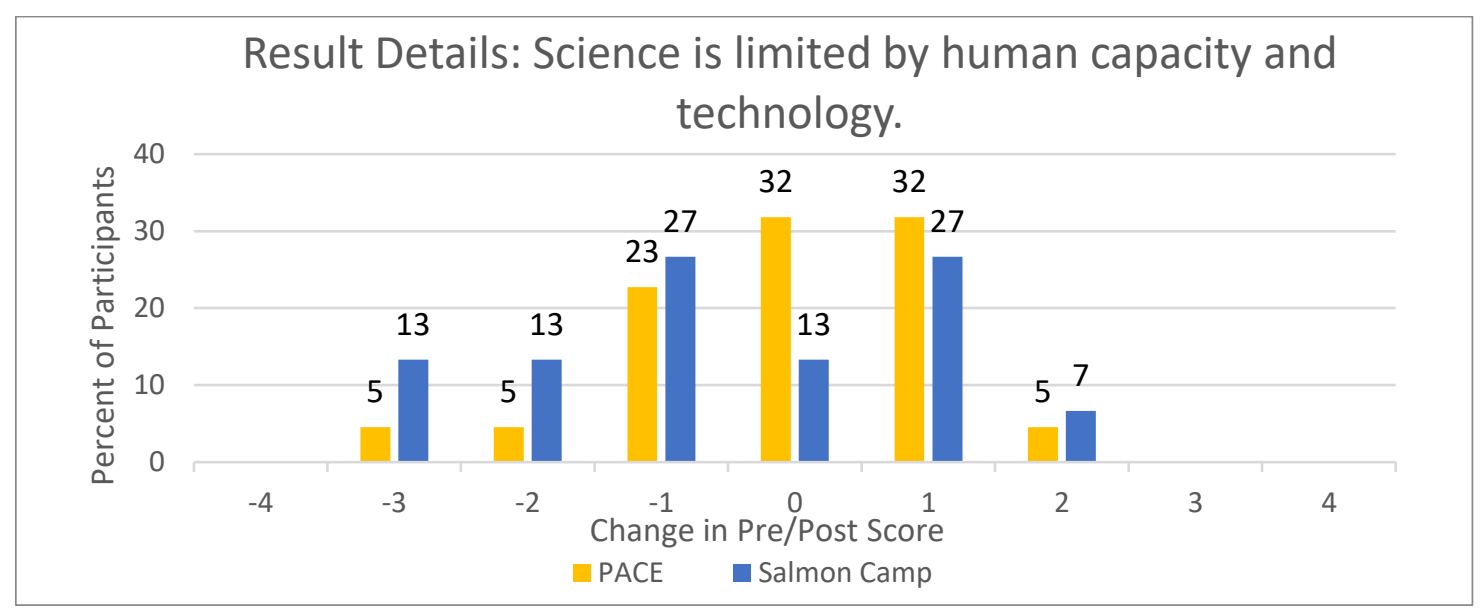

\begin{tabular}{|c|c|c|}
\hline \multicolumn{3}{|c|}{ Result Details: Science is limited by human capacity and technology. } \\
\hline & PACE Camp & Salmon Camp \\
\hline W-value: & 59 & 28 \\
\hline Mean Difference: & 0.33 & 0.08 \\
\hline Sum of pos. ranks: & 61 & 50 \\
\hline Sum of neg. ranks: & 59 & 28 \\
\hline Z-value: & -0.0568 & -0.8629 \\
\hline Mean $(W)$ : & 60 & 39 \\
\hline Standard Deviation $(\mathrm{W})$ : & 17.61 & 12.75 \\
\hline $\mathrm{P}$-value $(\mathrm{P} \leq 0.05)$ & 0.95216 & 0.38978 \\
\hline Sample size $(\mathrm{N})$ : & 15 & 12 \\
\hline Ceiling: & 0 & 0 \\
\hline
\end{tabular}


Statement 15: Scientific concepts and discoveries can cause new problems for people.

The Wilcoxon-Signed Ranked Test statistical analysis indicates there were no significant changes (at $\mathrm{p} \leq 0.05)$ for PACE or Salmon Camp responses. Figure 20 shows no shift for either camp. PACE responses were $36 \%$ with a one point decrease, $32 \%$ no change, and $23 \%$ one point increase. Salmon Camp responses were $47 \%$ with a one point decrease and $40 \%$ unchanged. The lowest observed change in responses for PACE was 3, and for Salmon Camp, -1 .

Figure 23 Result details for survey statement "Scientific concepts and discoveries can cause new problems for people."

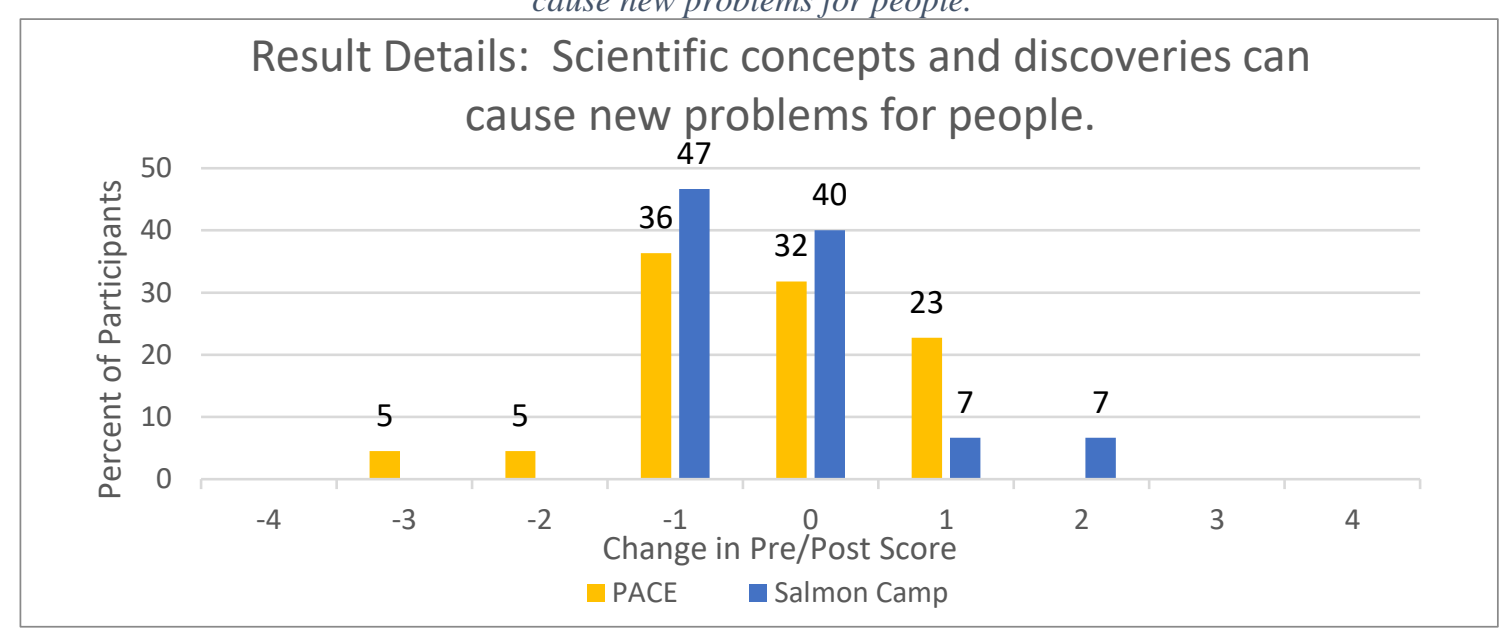

\begin{tabular}{|c|c|c|}
\hline \multicolumn{3}{|c|}{$\begin{array}{l}\text { Result Details: Scientific concepts and discoveries can cause new } \\
\text { problems for people. }\end{array}$} \\
\hline & PACE Camp & Salmon Camp \\
\hline W-value: & 35 & 12 \\
\hline ean Difference: & 0.93 & -0.5 \\
\hline Sum of pos. ranks: & 85 & 24 \\
\hline Sum of neg. ranks: & 35 & 12 \\
\hline Z-value: & -1.4199 & -0.8402 \\
\hline $\operatorname{Mean}(\mathrm{W})$ : & 60 & ( $\mathrm{N}$ too small) \\
\hline Standard Deviation (W): & 17.61 & \\
\hline $\mathrm{P}$-value $(\mathrm{P} \leq 0.05)$ & 0.1556 & \\
\hline Sample size $(\mathrm{N})$ : & 15 & 8 \\
\hline Ceiling: & 0 & 0 \\
\hline
\end{tabular}


Statement 16: Scientific knowledge is not responsible for society's decisions.

The Wilcoxon-Signed Ranked Test statistical analysis indicates there were no significant changes (at $\mathrm{p} \leq 0.05$ ) for PACE or Salmon Camp responses. Figure 21 shows no shift for either camp. PACE responses were $32 \%$ unchanged and $32 \%$ with a one point decrease. Salmon Camp responses were 33\% unchanged. The lowest observed change in responses for PACE was -2, and for Salmon Camp, -3.

Figure 24 Result details for survey statement "Scientific knowledge is not responsible for society's decisions."

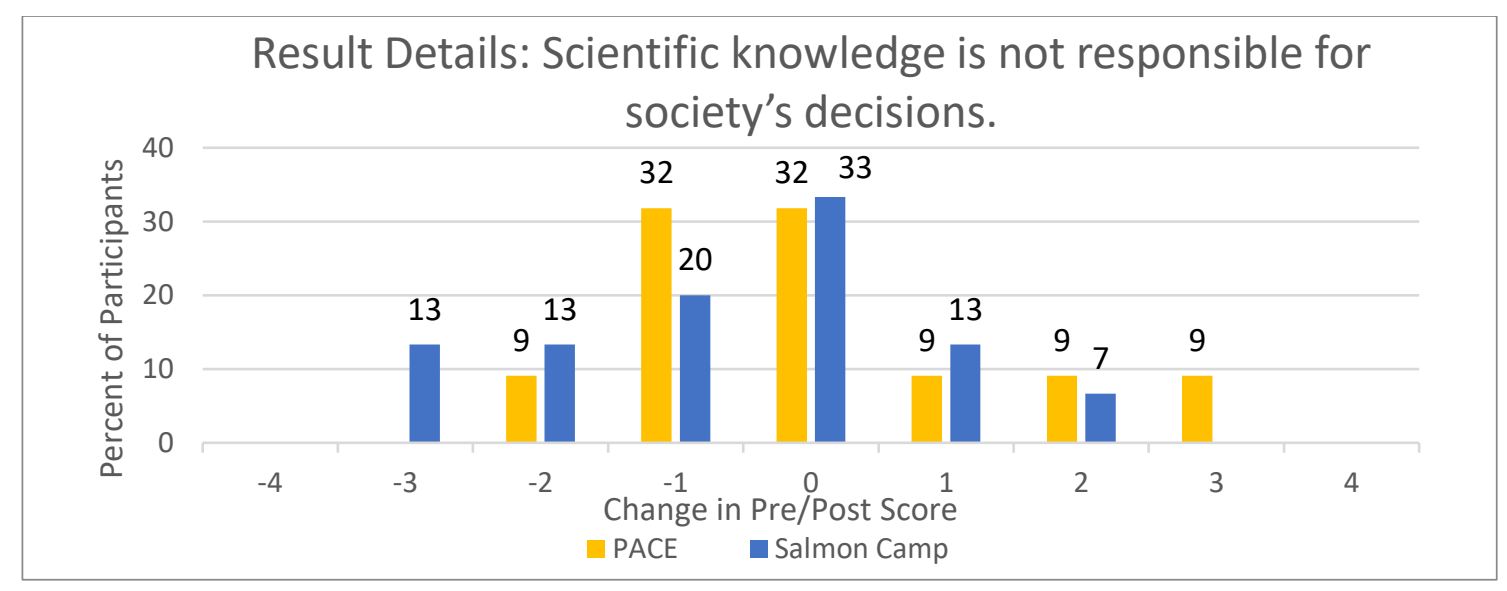

\begin{tabular}{|c|c|c|}
\hline \multicolumn{3}{|c|}{ Result Details: Scientific knowledge is not responsible for society's decisions. } \\
\hline & PACE Camp & Salmon Camp \\
\hline W-value: & 58 & 13 \\
\hline Mean Difference: & 0.27 & -0.33 \\
\hline Sum of pos. ranks: & 58 & 32 \\
\hline Sum of neg. ranks: & 62 & 13 \\
\hline Z-value: & -0.1136 & -1.1255 \\
\hline Mean $(W)$ : & 60 & (N too small) \\
\hline Standard Deviation $(\mathrm{W})$ : & 17.61 & \\
\hline $\mathrm{P}$-value $(\mathrm{P} \leq 0.05)$ & 0.9124 & \\
\hline Sample size $(\mathrm{N})$ : & 15 & 9 \\
\hline Ceiling: & 0 & 0 \\
\hline
\end{tabular}


The Wilcoxon-Signed Ranked Test was used to calculate significant positive shift in eight of the sixteen statements for Salmon Camp responses, while no change was exhibited in any PACE responses.

Table 10 Summary table of changes in Salmon Camp responses for each survey statement.

\begin{tabular}{|c|c|c|}
\hline & Survey Statement & $\begin{array}{c}\text { Change in Salmon } \\
\text { Camp Pre/Post } \\
\text { Response }\end{array}$ \\
\hline \multirow{4}{*}{$\begin{array}{l}\text { Science is a } \\
\text { Way of } \\
\text { Knowing }\end{array}$} & 1. Science is built upon years of knowledge. & + \\
\hline & 2. Science is a solitary pursuit. & + \\
\hline & 3. Citizens use science every day. & + \\
\hline & $\begin{array}{l}\text { 4. Observations by citizens do not contribute to scientific } \\
\text { knowledge. }\end{array}$ & + \\
\hline \multirow{4}{*}{$\begin{array}{l}\text { Scientific } \\
\text { Knowledge } \\
\text { Assumes an } \\
\text { Order and } \\
\text { Consistency in } \\
\text { Natural } \\
\text { Systems }\end{array}$} & $\begin{array}{l}\text { 5. Science can study things and events that happened in the } \\
\text { past, even if no one was there to observe it. }\end{array}$ & + \\
\hline & 6. Science is based on observation of natural patterns & + \\
\hline & $\begin{array}{l}\text { 7. We accept an idea as scientific knowledge only if it } \\
\text { doesn't have any errors. }\end{array}$ & none \\
\hline & 8. Science data can be interpreted in new ways. & + \\
\hline \multirow{5}{*}{$\begin{array}{l}\text { Science is a } \\
\text { Human } \\
\text { Endeavor }\end{array}$} & 9. Anyone can be a scientist. & + \\
\hline & $\begin{array}{l}\text { 10. People from all over the world contribute to science } \\
\text { knowledge }\end{array}$ & none \\
\hline & 11. Scientists rarely use creativity. & none \\
\hline & $\begin{array}{l}\text { 12. Disagreement between scientists is one of the weaknesses } \\
\text { of science. }\end{array}$ & none \\
\hline & $\begin{array}{l}\text { 13. Advances in technology influence the progress of } \\
\text { science. }\end{array}$ & none \\
\hline \multirow{3}{*}{$\begin{array}{l}\text { Science } \\
\text { Addresses } \\
\text { Questions } \\
\text { About the } \\
\text { Natural and } \\
\text { Material World }\end{array}$} & 14. Science is limited by human capacity and technology. & none \\
\hline & $\begin{array}{l}\text { 15. Scientific concepts and discoveries can cause new } \\
\text { problems for people. }\end{array}$ & none \\
\hline & $\begin{array}{l}\text { 16. Scientific knowledge is not responsible for society's } \\
\text { decisions. }\end{array}$ & none \\
\hline
\end{tabular}

Analysis of the survey statements associated with NGSS NOS concepts were collectively compared using the Wilcoxon-Signed Ranked Test. There were no significant shifts in PACE responses, and the summary table below shows the change in Salmon Camp responses. The following figures show the result details from this analysis. 
Table 11 Summary table of changes in Salmon Camp responses for NGSS NOS concepts, compiled from survey statements.

\begin{tabular}{|l|c|}
\hline \multicolumn{1}{|c|}{ NGSS NOS Concept } & $\begin{array}{c}\text { Change in Salmon } \\
\text { Camp Pre/Post } \\
\text { Responses }\end{array}$ \\
+ & + \\
\hline $\begin{array}{l}\text { Science is a way of knowing } \\
\text { Scientific knowledge assumes an order and consistency in natural }\end{array}$ & + \\
\hline Science is a human endeavor & none \\
\hline Science addresses questions about the natural and material world & none \\
\hline
\end{tabular}

Survey Section 2 Results for NGSS NOS Concept: Science is a Way of

\section{Knowing}

The Wilcoxon-Signed Ranked Test statistical analysis indicates there were no significant changes $($ at $\mathrm{p} \leq 0.05)$ for PACE responses and a significant positive change for Salmon Camp responses $(\mathrm{p}=0)$. Responses for PACE were 57\% unchanged, while Salmon Camp responses increased by one point for $32 \%$ of participants and two points or more $44 \%$ of participants. No changes were below -2 . 
Figure 25 Result details for NGSS NOS concept "Science is a way of knowing."

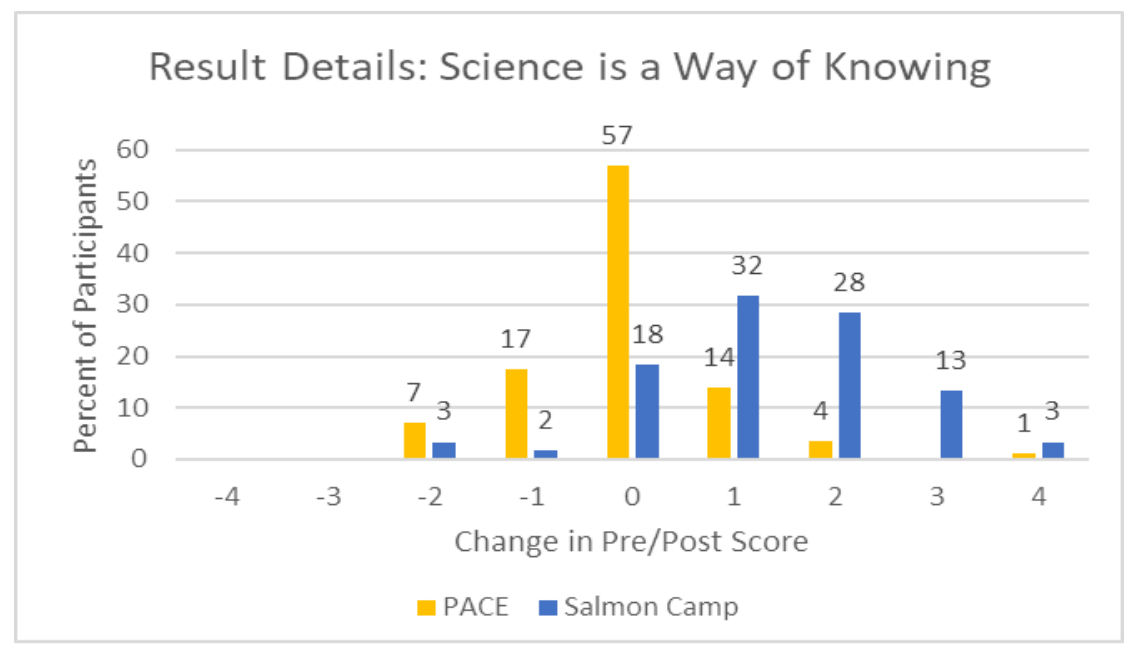

PACE Result Details
W-value: 301
Mean Difference: -0.74
Sum of pos. ranks: 479
Sum of neg. ranks: 301
Z-value: -1.242
Mean $(W): 390$
Standard Deviation $(W):$
71.66
Sample Size $(N): 39$
P-value: 0.21498
The result
is not significant at $\mathrm{p} \leq$
0.05.

Salmon Camp Result Details

W-value: 70.5

Mean Difference: -2.08

Sum of pos. ranks: 70.5

Sum of neg. ranks: 1154.5

Z-value: -5.3914

Mean $(W): 612.5$

Standard Deviation $(W)$ :

100.53

Sample Size $(N): 49$

P-value: 0.

The result is significant at $p \leq$ 0.05 .

\section{Survey Section 2 Results for NGSS NOS Concept: Scientific Knowledge}

\section{Assumes an Order and Consistency in Natural Systems}

The Wilcoxon-Signed Ranked Test statistical analysis indicates there were no significant changes (at $\mathrm{p} \leq 0.05$ ) for PACE responses and a significant positive change for Salmon Camp responses $(\mathrm{p}=0)$. Responses for PACE were 50\% unchanged, while 
Salmon Camp responses increased by one point for $29 \%$ of participants and two points or more $43 \%$ of participants. No changes were below -3 .

Figure 26 Result details for NGSS NOS concept "Scientific knowledge assumes an order and consistency in natural systems."

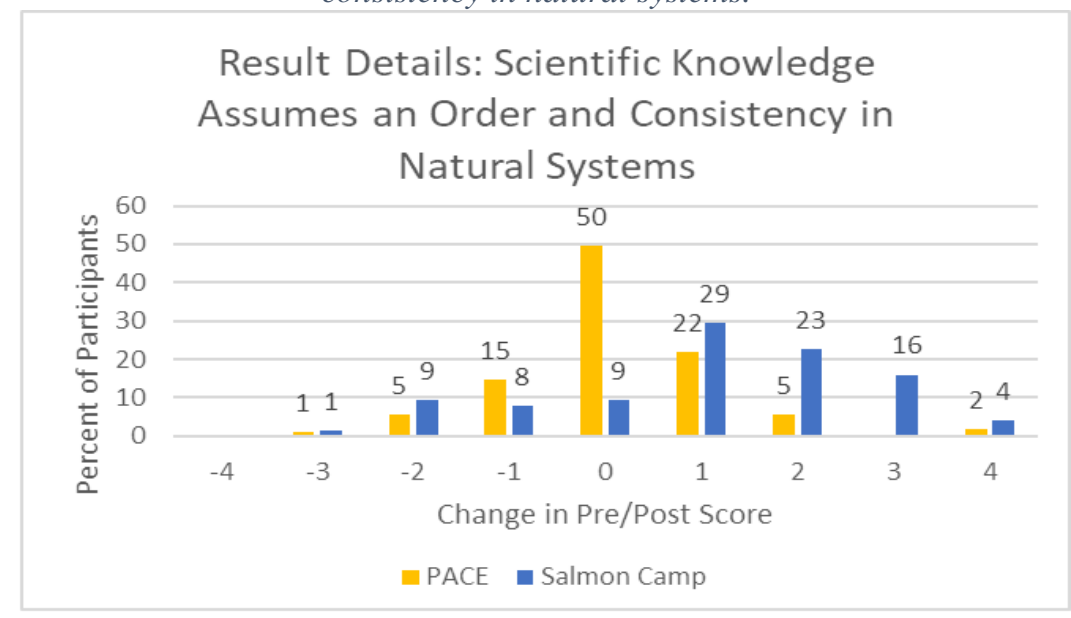

PACE Result Details
W-value: 660
Mean Difference: -0.96
Sum of pos. ranks: 660
Sum of neg. ranks: 936
Z-value: -1.1257
Mean ( $W$ : 798
Standard Deviation $(W)$ :
122.59
Sample Size $(N): 56$
P-value: 0.25848
The result
is not significant at $\mathrm{p} \leq$
0.05 .

$\underline{\text { Salmon Camp Result Details }}$

W-value: 429.5

Mean Difference: -0.5

Sum of pos. ranks: 429.5

Sum of neg. ranks: 1916.5

Z-value: -4.543

Mean (W): 1173

Standard Deviation $(W)$ :

163.66

Sample Size $(N): 68$

P-value: 0

The result is significant at $p \leq$ 0.05 . 


\section{Survey Section 2 Results for NGSS NOS Concept: Science is a Human}

\section{Endeavor}

The Wilcoxon-Signed Ranked Test statistical analysis indicates there were no significant changes (at $p \leq 0.05)$ for PACE or Salmon Camp responses. Figure 24 shows no shift for either camp. Responses for PACE were 54\% unchanged, while Salmon Camp responses were $31 \%$ unchanged. Camp responses were evenly distributed otherwise.

Figure 27 Result details for NGSS NOS concept "Science is a human endeavor."

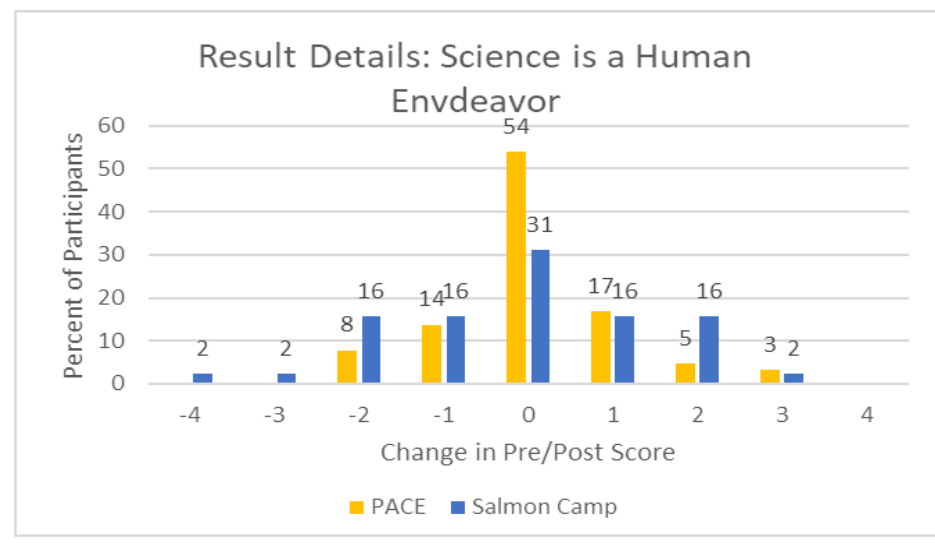

PACE Result Details
W-value: 248
Mean Difference: -1.68
Sum of pos. ranks: 248
Sum of neg. ranks: 248
Z-value: 0
Mean ( $W$ : 248
Standard Deviation $(W)$ :
51.03
Sample Size $(N): 31$
P-value: 1
The result
is not significant at $\mathrm{p} \leq$
0.05 .

Salmon Camp Result Details

W-value: 232.5

Mean Difference: 0.9

Sum of pos. ranks: 263.5

Sum of neg. ranks: 232.5

Z-value: -0.3037

Mean (W): 248

Standard Deviation $(W)$ :

51.03

Sample Size $(N): 31$

P-value is 0.76418 .

The result is not significant at $p \leq 0.05$. 


\section{Survey Section 2 Results for NGSS NOS Concept: Science Addresses}

\section{Questions About the Natural and Material World}

The Wilcoxon-Signed Ranked Test statistical analysis indicates there were no significant changes $($ at $p \leq 0.05)$ for PACE or Salmon Camp responses. Figure 25 shows no shift for either camp. Responses for PACE were $85 \%$ unchanged or had only a onepoint change. Salmon Camp responses were $76 \%$ unchanged or had only one-point change.

Figure 28 Result details for NGSS NOS concept "Science addresses questions about the natural and material world."

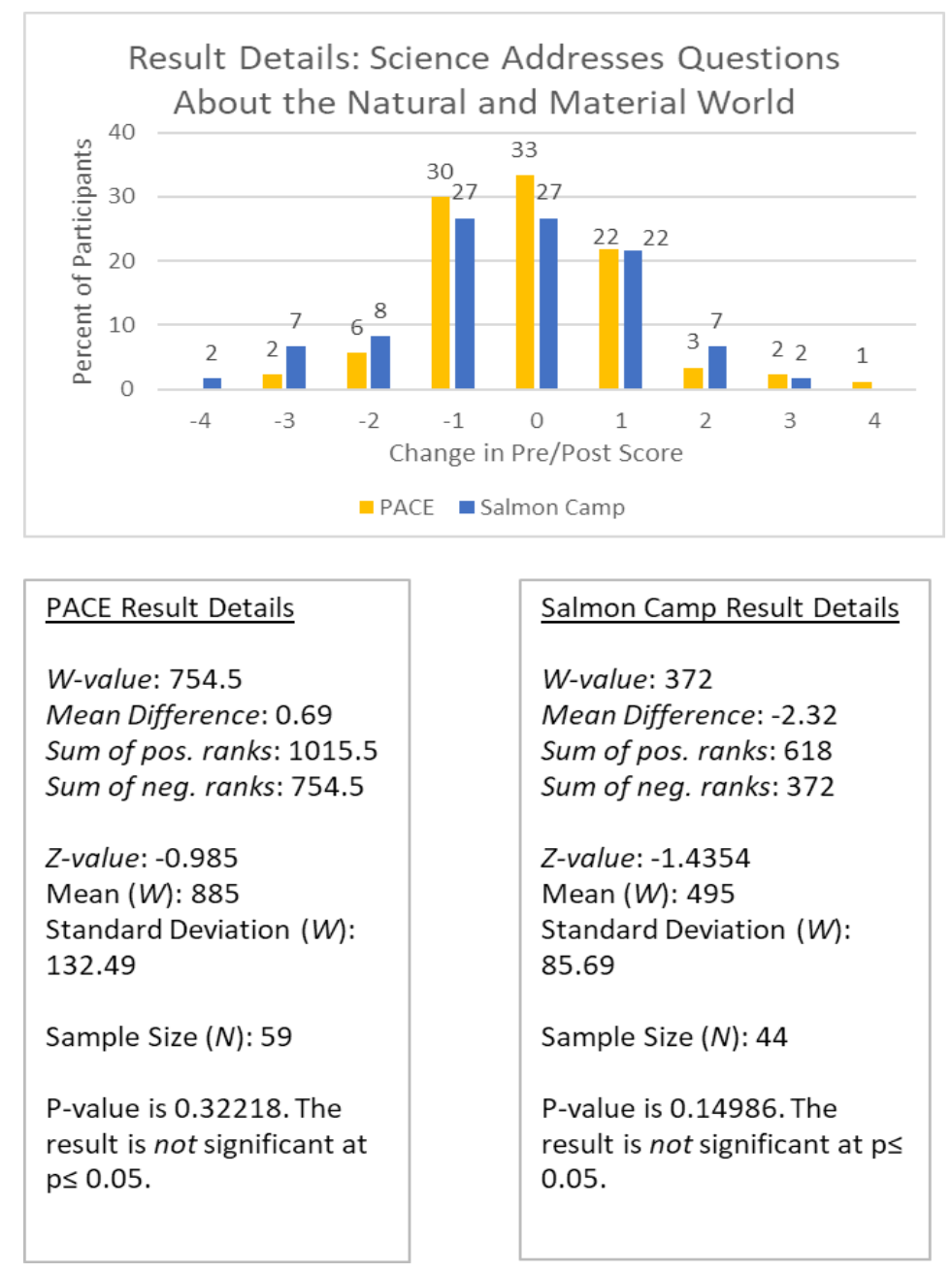




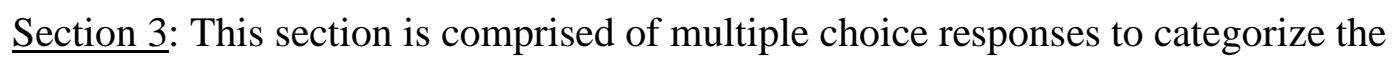
statements into knowledge bases (TEK, Western Science, Both, Neither). The statements were derived from the NGSS NOS Middle School Learning Expectations and modified into neutral statements (i.e. replace "science" with "knowledge"). The result details for each statement shows the percent of pre and post responses for each camp. The data was further compiled into NGSS NOS concepts for comparison. 
Knowledge Statement 1: Knowledge is cumulative (continually built upon from prior knowledge).

Responses to Knowledge Statement 1 are varied for each camp. The result details for PACE display a 7\% increase in identifying the statement as "both" TEK and Western science, moving from $60 \%$ to $67 \%$. Also for PACE, a $16 \%$ decrease in responses for "TEK" were observed with a 9\% increase in responses for "science". Salmon Camp responses increased $14 \%$ for identifying the statement as "both" TEK and Western science, from $36 \%$ to $50 \%$. In comparison, PACE responses favored "both" TEK and Western science 17\% more than Salmon Camp. 
Figure 29 Result details for survey statement "Knowledge is cumulative (continually build upon from prior knowledge)."

Result Details: Knowledge is cumulative (continually built upon from prior knowledge).

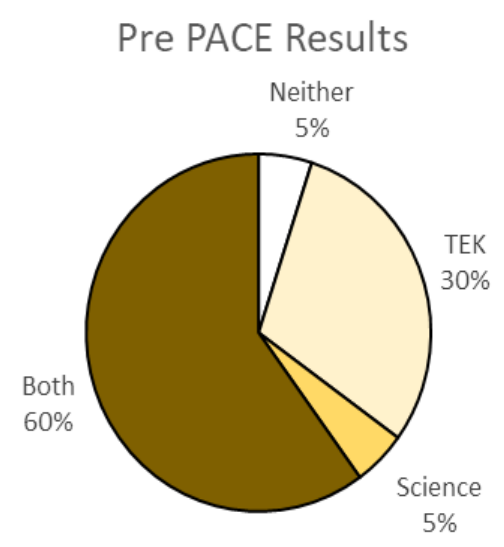

Pre Salmon Camp Results
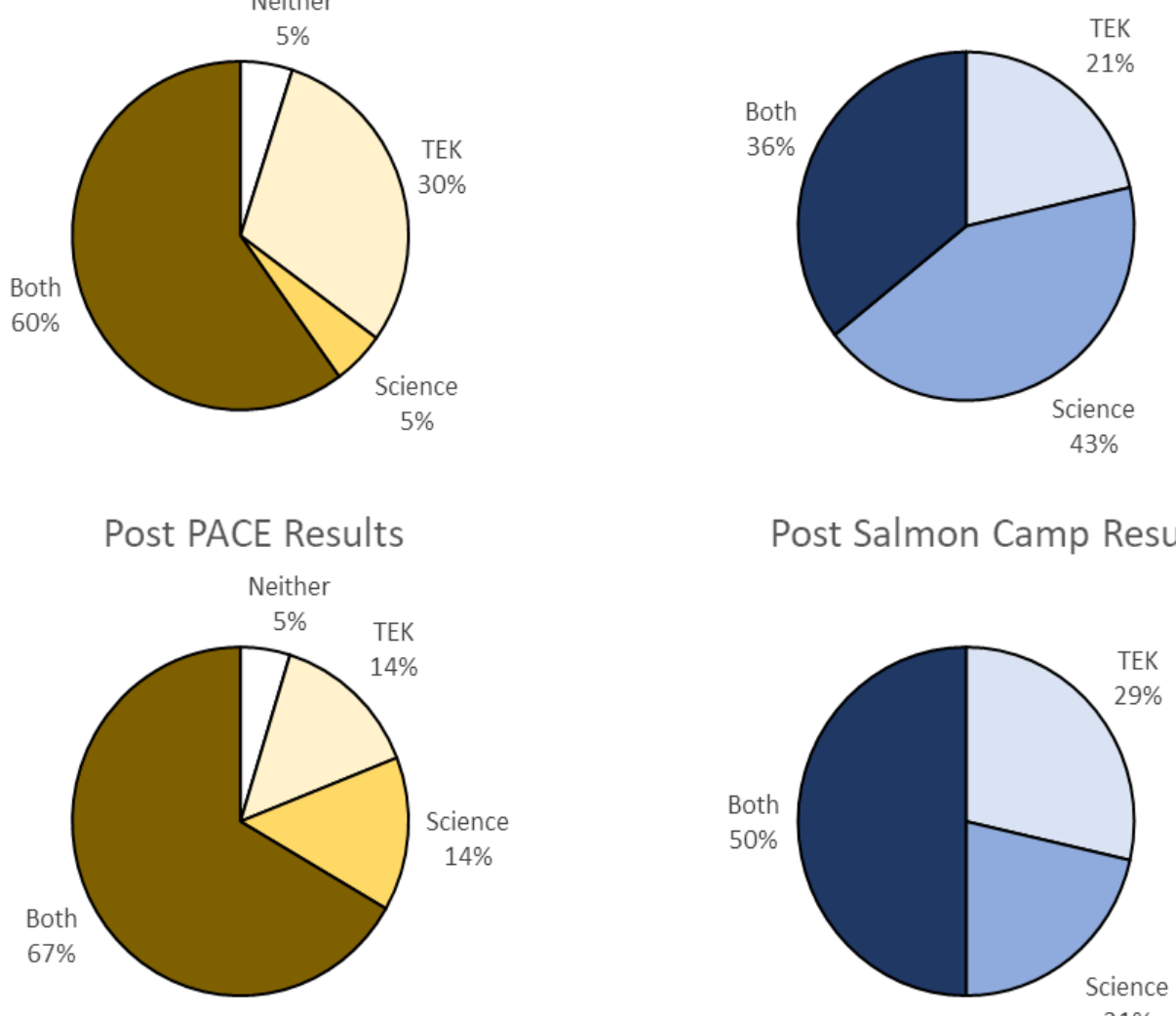

Post Salmon Camp Results

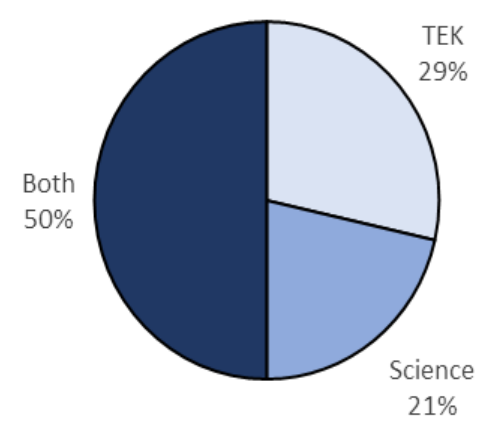


Knowledge Statement 2: Many people, from many generations and nations, have contributed to our knowledge.

Responses to Knowledge Statement 2 for each camp are varied. The result details for PACE display a 10\% increase in identifying the statement as "both" TEK and Western science, moving from $35 \%$ to $45 \%$. Salmon Camp responses for the pre survey indicated 64\% "both" and 36\% "TEK". Salmon Camp post survey responses indicated a $21 \%$ reduction for identifying the statement as "both" TEK and Western science, with an increase in "TEK" responses (13\%) and in "science" (14\%). The post survey result details show comparable "both" responses for the camps, with PACE (45\%) and Salmon

Figure 30 Result details for survey statement "Many people, from many generations and nations, have contributed to our knowledge."

Result Details: Many people, from many generations and nations, have contributed to our knowledge.

Pre PACE Results

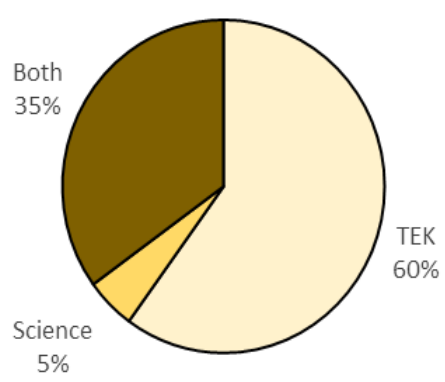

Post PACE Results

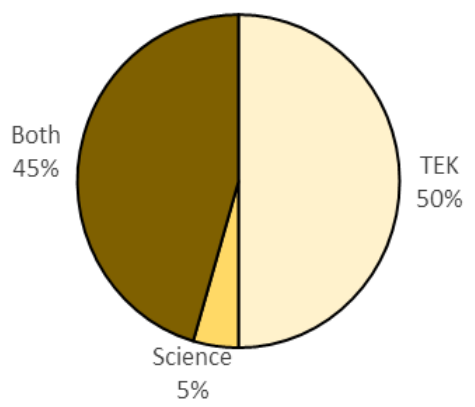

Pre Salmon Camp Results

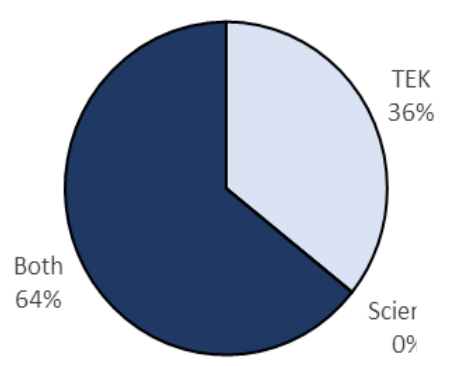

Post Salmon Camp Results

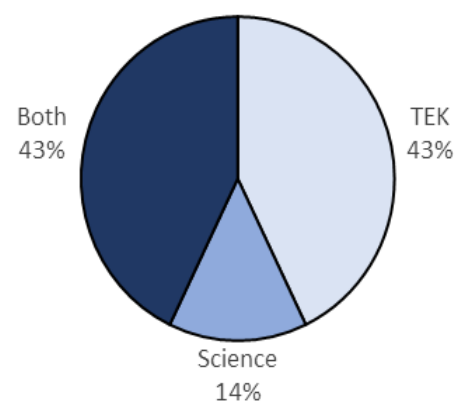


Knowledge Statement 3: Different sources of knowledge can be used together and benefit one another.

Responses to Knowledge Statement 3 are varied for each camp. The result details for PACE show a $21 \%$ increase in identifying the statement as "both" TEK and Western science, moving from $65 \%$ to $86 \%$. Also for PACE, no post responses identify the statement as "TEK". Salmon Camp responses increased by $27 \%$ for identifying the statement as "both" TEK and Western science, from $50 \%$ to $77 \%$. In comparison, PACE responses were $9 \%$ higher than Salmon Camp responses for "both" in the post survey.

Figure 31 Result details for survey statement "Different source of knowledge can be used together to benefit one another."

Result Details: Different sources of knowledge can be used together and benefit one another.

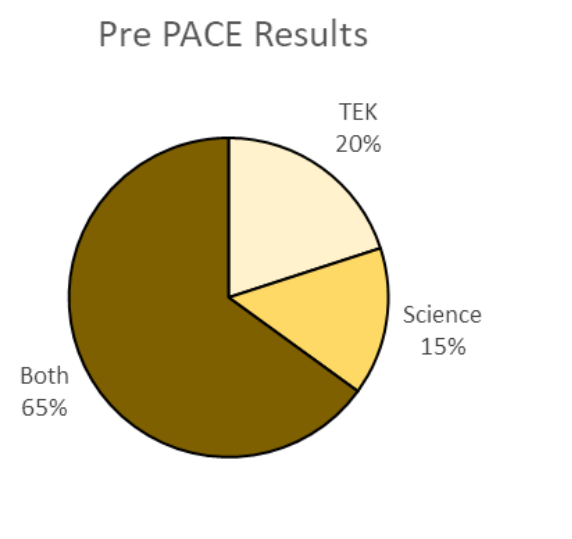

\section{Pre Salmon Camp Results}
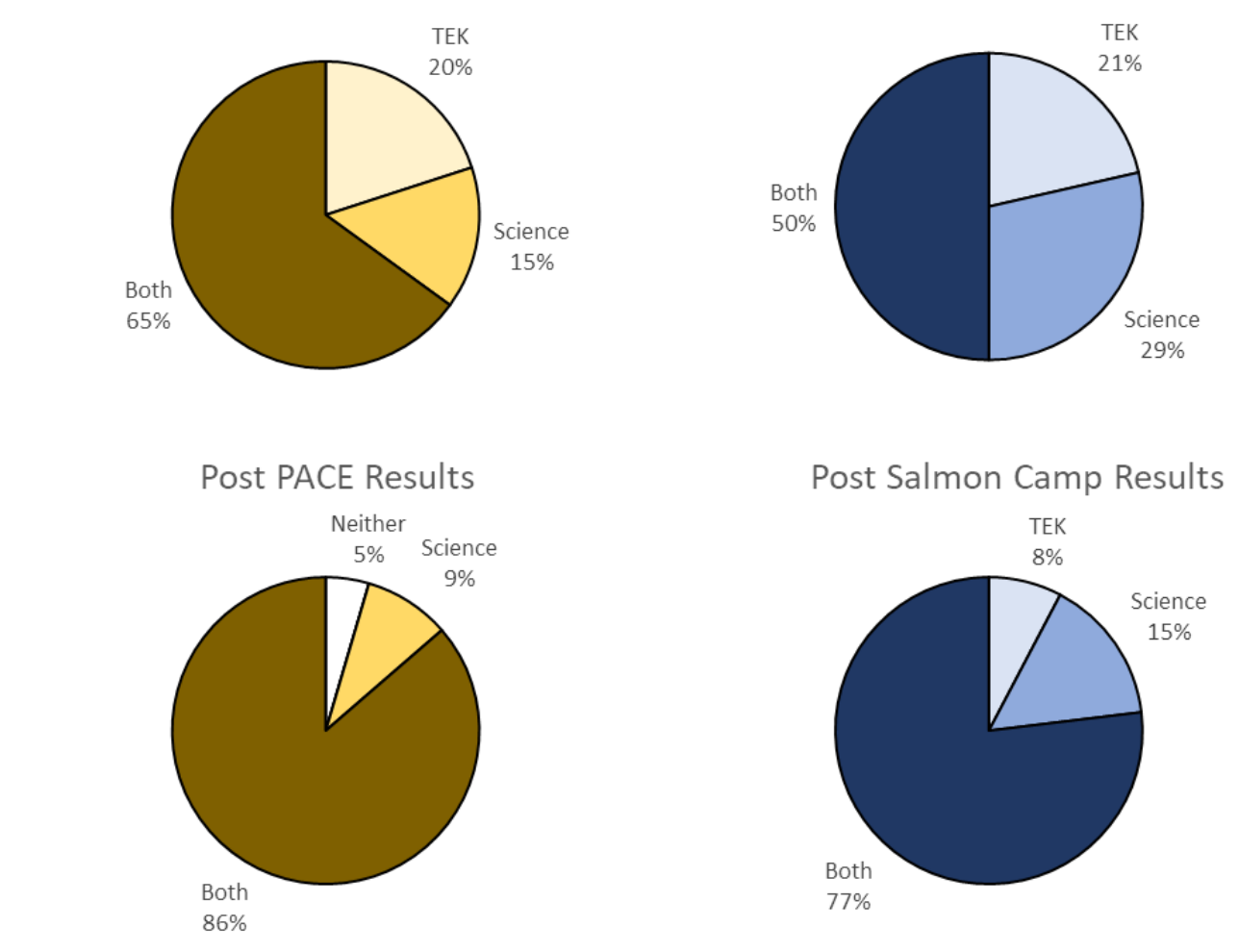
Knowledge Statement 4: Patterns in nature can be observed and measured.

Responses to Knowledge Statement 4 are similar for both camps. The result details for PACE and Salmon Camp demonstrate a $25 \%$ increase in identifying the statement as "both" TEK and Western science, moving from $30 \%$ to $55 \%$ and $29 \%$ to $54 \%$, respectively. For both camps, pre survey responses favored "science" as the knowledge base the statement is associated to with $45 \%$ (PACE) and $57 \%$ (Salmon Camp).

Figure 32 Result details for survey statement "Patterns in nature can be observed and measured."

Result Details: Patterns in nature can be observed and measured.

\section{Pre PACE Results}

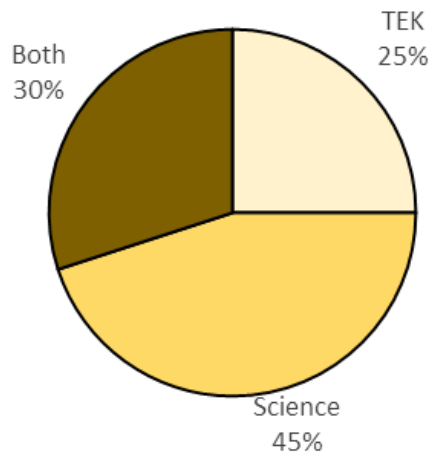

Post PACE Results

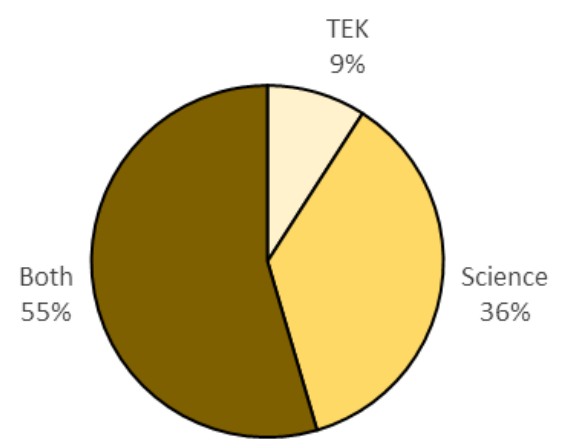

Pre Salmon Camp Results

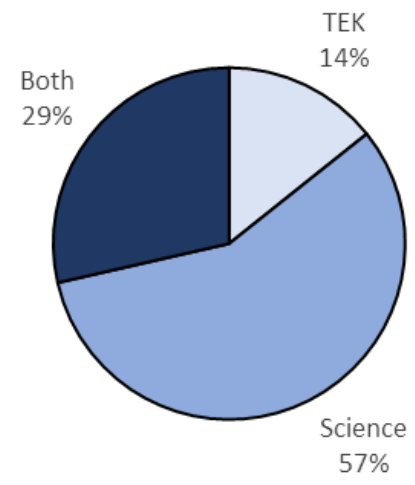

Post Salmon Camp Results

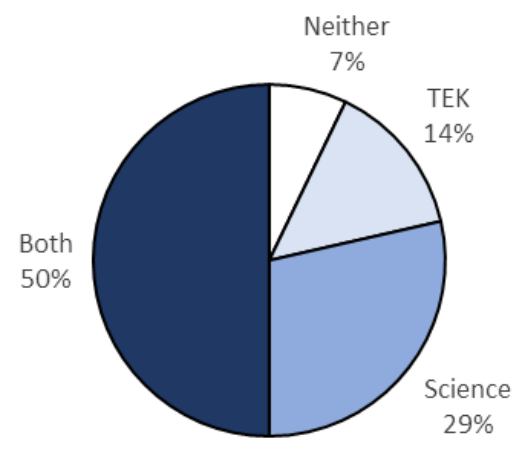


Knowledge Statement 5: Inconsistencies or changes are considered and evaluated.

The responses for each camp are varied. PACE responses exhibited little change overall with pre survey responses for "both" increasing by $10 \%$ and "science" responses decreasing by $12 \%$. Salmon Camp responses on the pre survey were indicated "both" and "science" at 43\%. Post survey results demonstrate a 14\% increase in "both" responses. Salmon Camp responses for "neither" increased by $15 \%$. There is a $21 \%$ difference in post responses indicating "both" knowledge bases between the camps.

Figure 33 Result details for survey statement " Inconsistencies or changes are considered and evaluated."

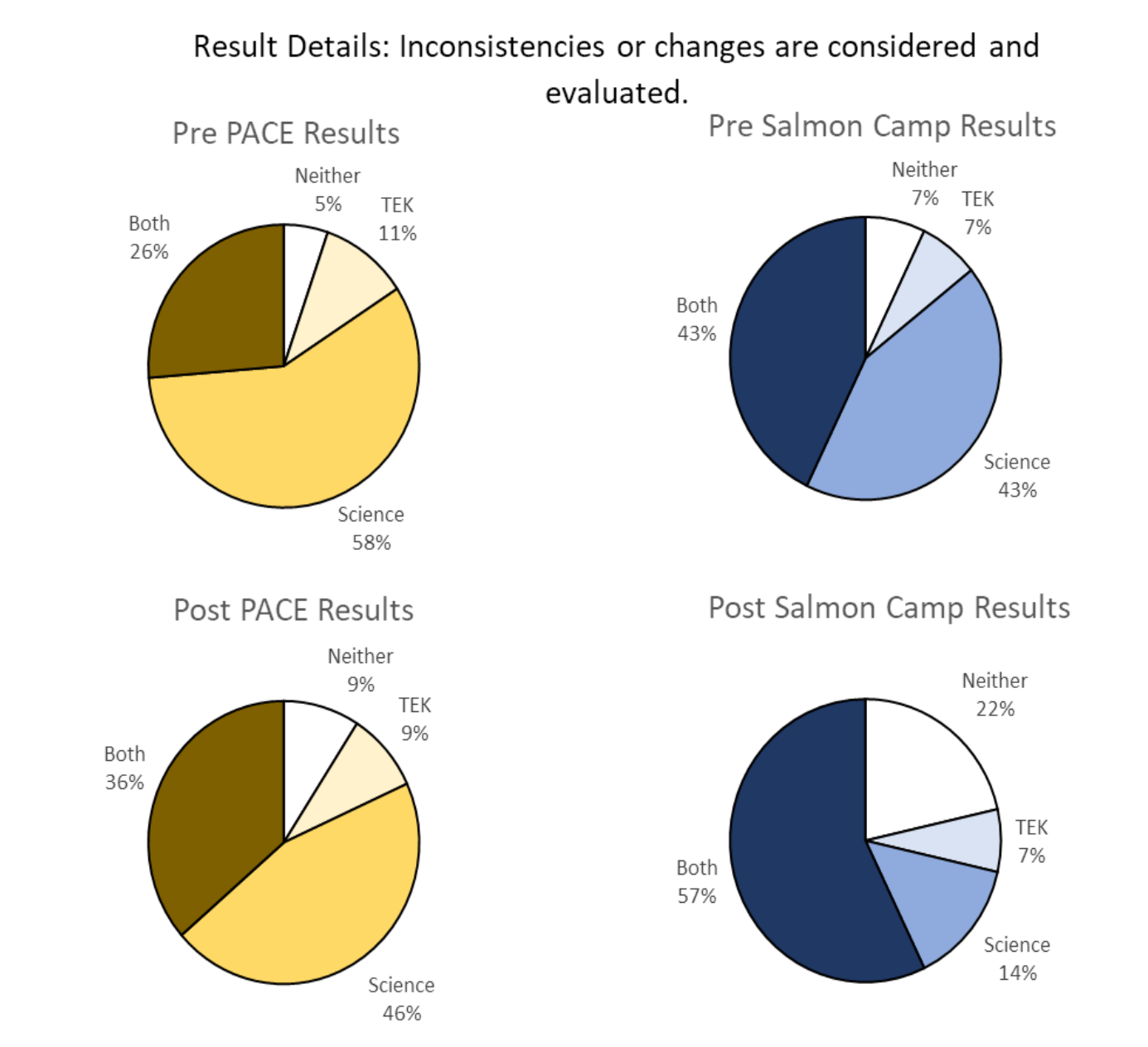


Knowledge Statement 6: Men, women and people from different backgrounds engage in building knowledge.

The pre and post survey responses for both camps had little change. PACE responses for "both" knowledge bases associated to the statement decreased from 55\% to 50\%, while "science" responses also decreased by 5\%. For Salmon Camp, responses favoring "both" knowledge bases remained at $64 \%$, while "TEK" responses increased by $8 \%$. In comparison, Salmon Camp had 14\% more responses for "both" knowledge bases in the post survey. 
Figure 34 Result details for survey statement "Men, women, and people from different backgrounds engage in building knowledge."

Result Details: Men, women and people from different backgrounds engage in building knowledge.

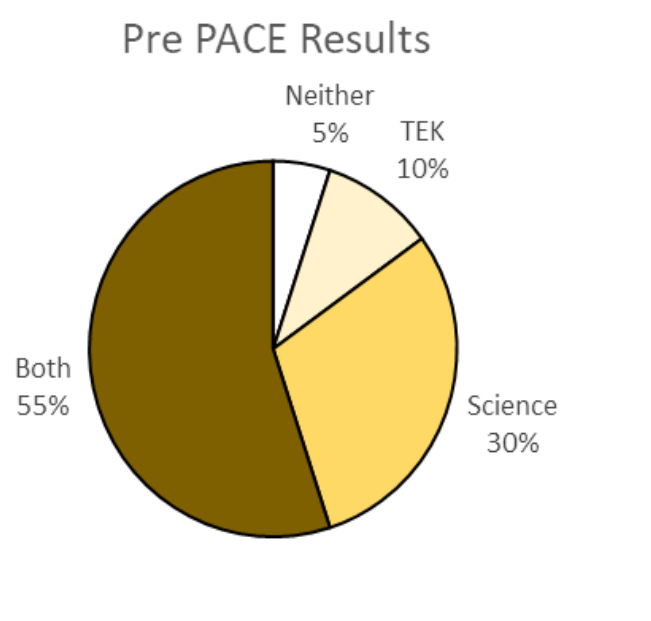

Pre Salmon Camp Results
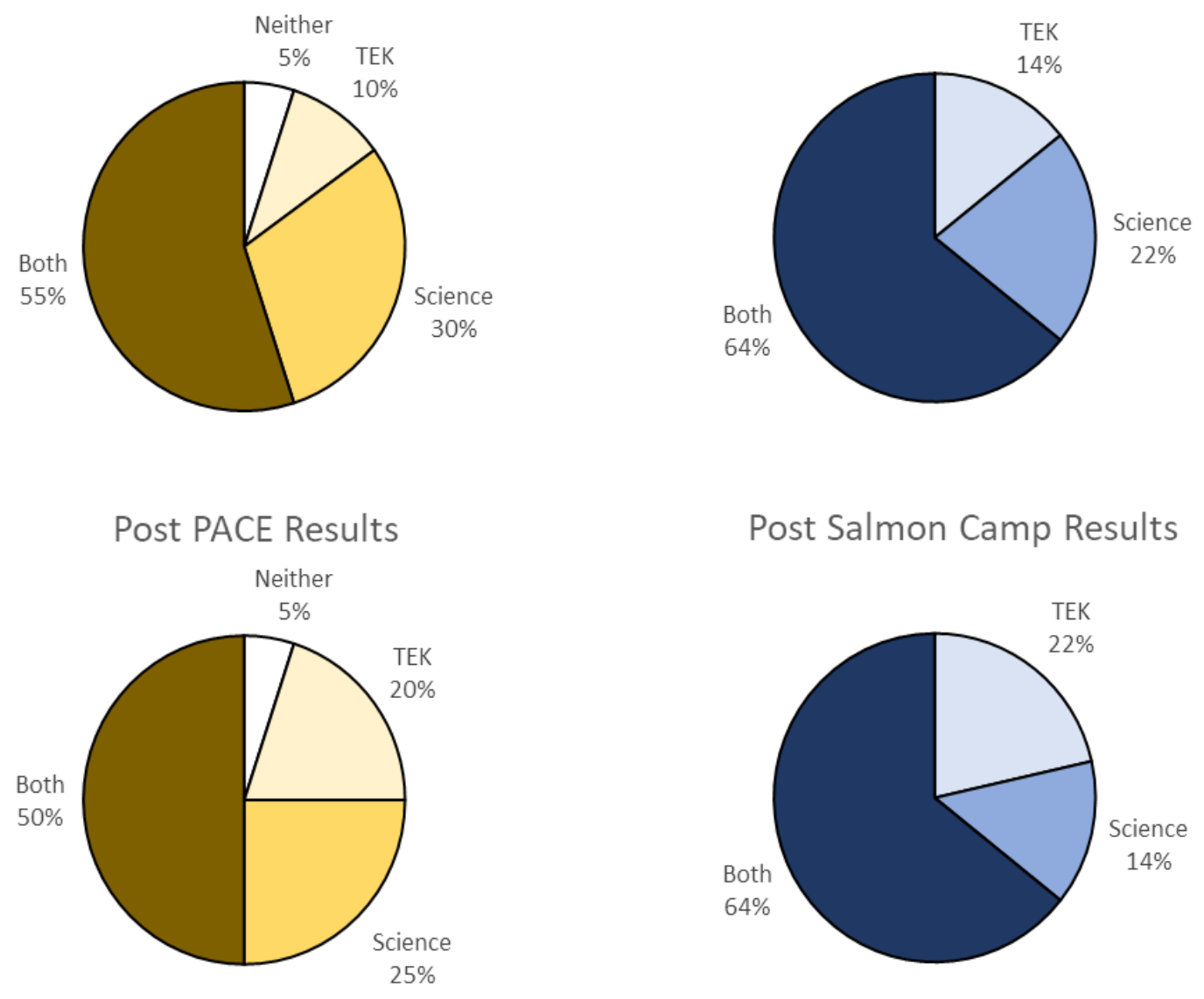

\section{Post Salmon Camp Results}

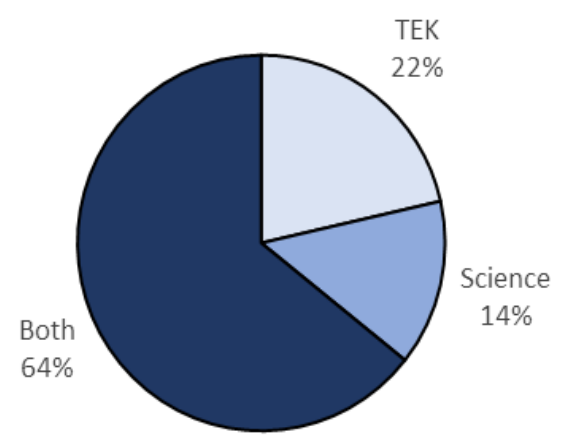


Knowledge Statement 7: Knowledge is based on observation of natural patterns.

Result details indicate similar pre survey responses indicating "both" knowledge bases for each camp with 55\% and 50\% for PACE and Salmon Camp respectively.

PACE post survey responses for "both" knowledge bases decreased to $36 \%$, and instead with $50 \%$ of the responses indicating the statement as associated to "TEK" $(15 \%$

Figure 35 Result details for survey statement "Knowledge is based on observation of natural patterns."

Result Details: Knowledge is based on observation of natural patterns.
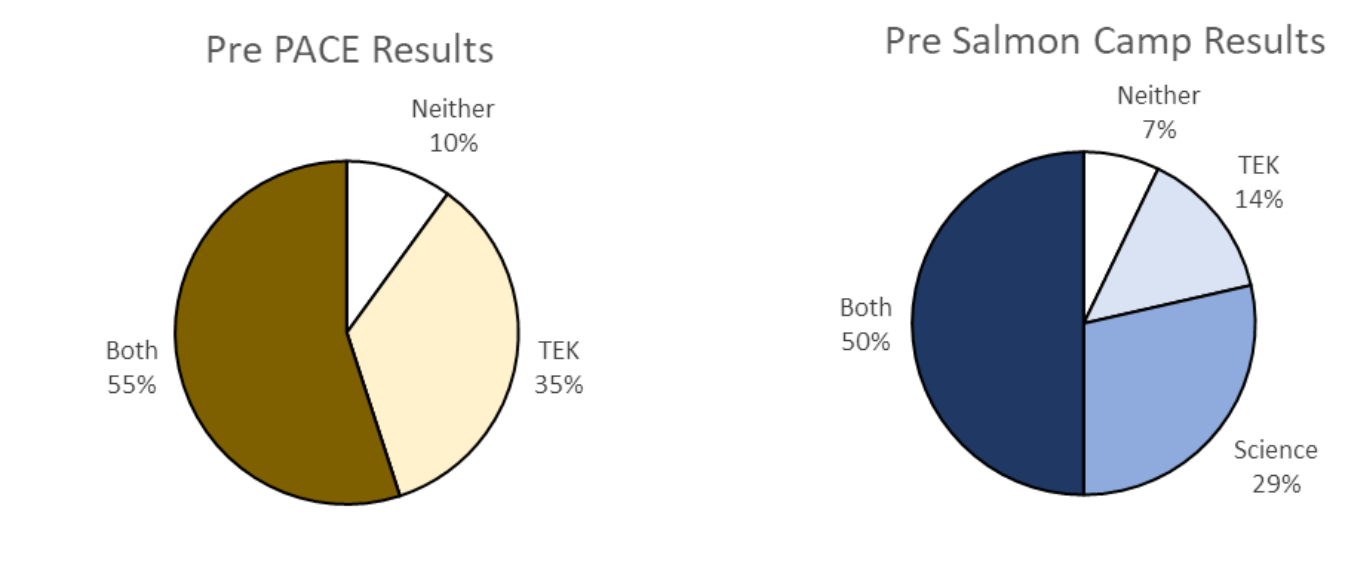

Post PACE Results

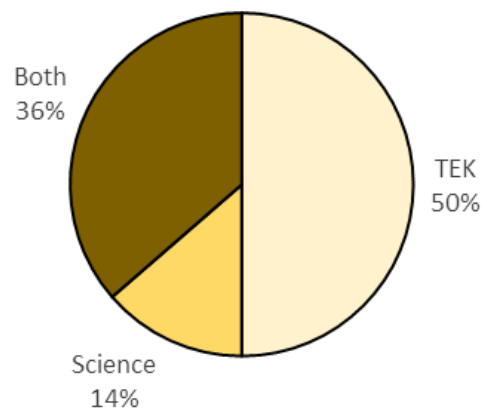

\section{Post Salmon Camp Results}

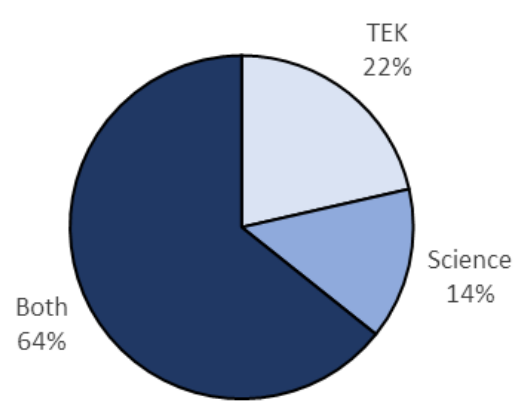

increase). Salmon Camp post survey responses had minimal changes with a $14 \%$ increase in responses indicating "both", a 15\% reduction in "science" responses, and an $8 \%$ increase in "TEK" responses. 
Knowledge Statement 8: Values like persistence, precision, reasoning, logic, imagination, and creativity are important.

Results for PACE had little change, while Salmon Camp results varies for pre and post responses. For PACE responses, the largest change was the $7 \%$ increase in responses identifying the statement as "science". Salmon Camp "science" responses increased from $29 \%$ to $50 \%$. In comparison, PACE responses for "both" knowledge bases associated to the statement was $18 \%$ higher than the Salmon Camp responses.

Figure 36 Result details for survey statement "Values like persistence, precision, reasoning, logic, imagination, and creativity are important."

Result Details: Values like persistence, precision, reasoning, logic, imagination, and creativity are important.

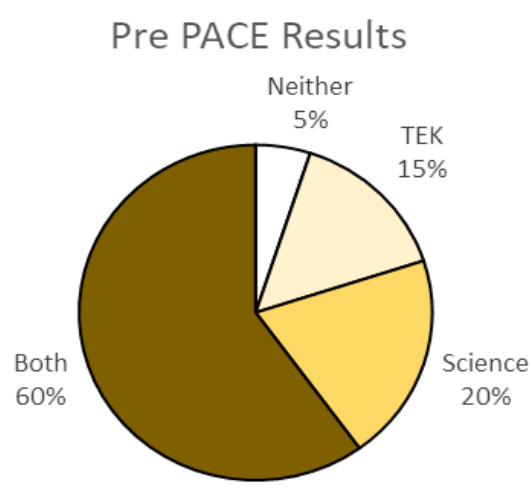

Pre Salmon Camp Results
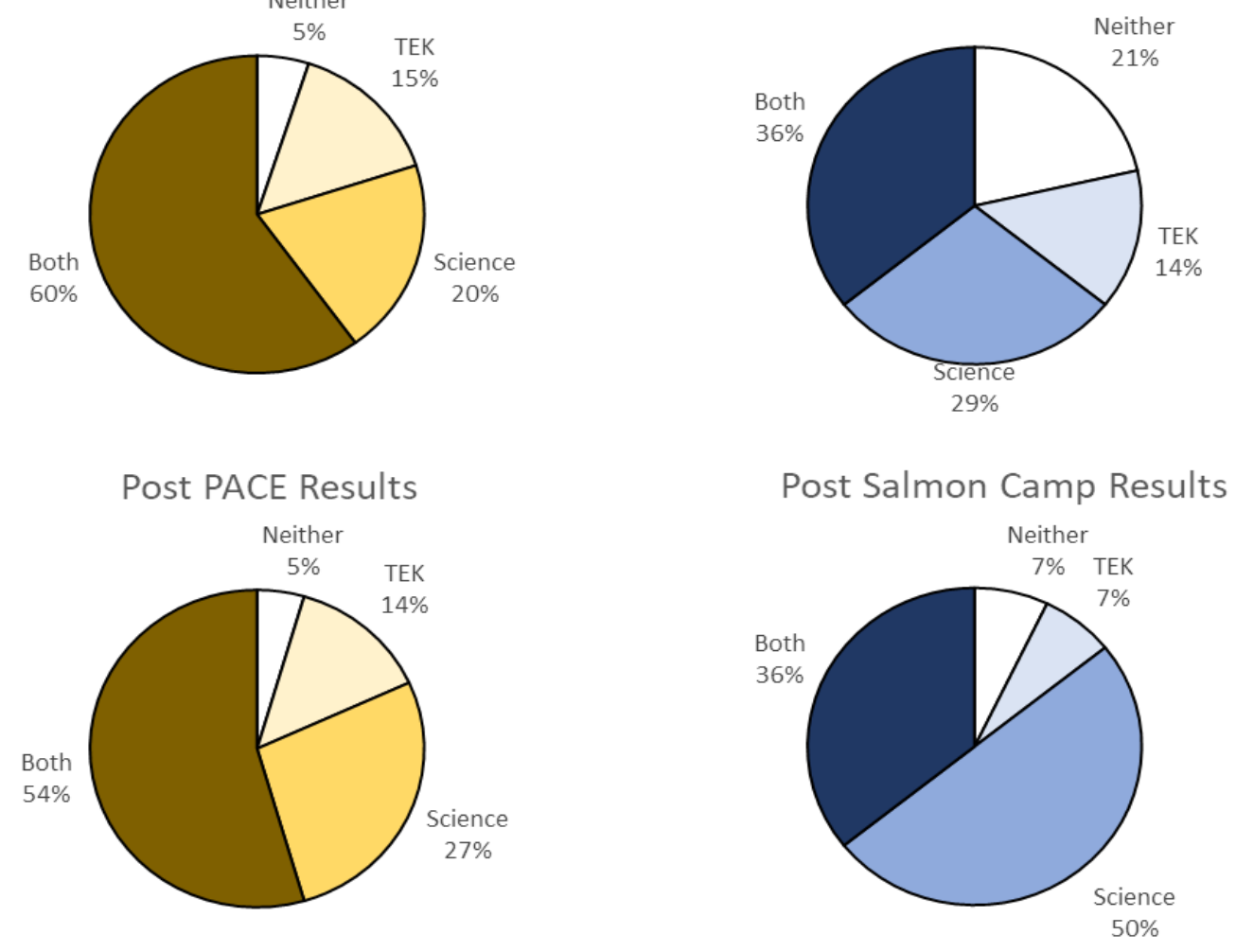
Knowledge Statement 9: Values like harmony, respect, resiliency, interdependence, and reciprocity (giving mutually) are important.

Responses for the camps were varied. For PACE, "TEK" was identified as the primary knowledge base associated with the statement (post survey 55\%). PACE responses indicate "both" knowledge bases were identified at $45 \%$ and $36 \%$ for the pre and post surveys, respectively. Salmon Camp responses had little change, "TEK" also

Figure 37 Result details for survey statement "Values like harmony, respect, resiliency, interdependence, and reciprocity (giving mutually) are important."

Result Details: Values like harmony, respect, resiliency, interdependence, and reciprocity (giving mutually) are important.

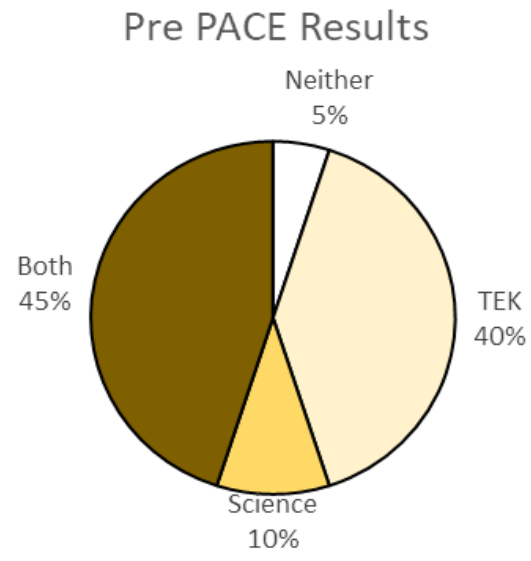

Post PACE Results

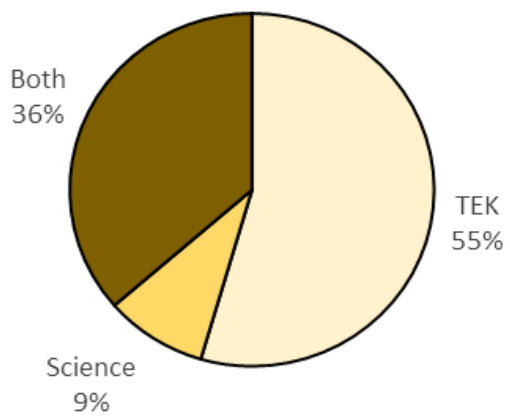

Pre Salmon Camp Results

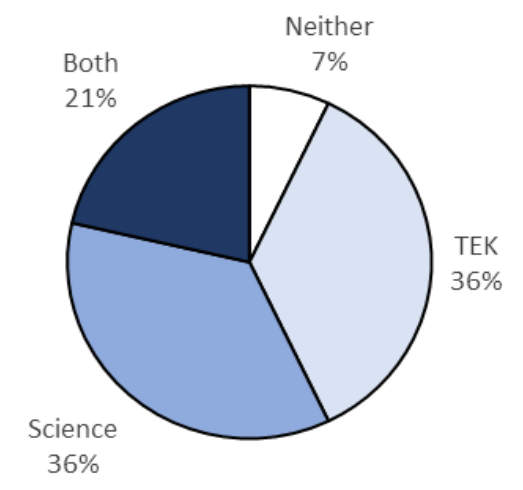

Post Salmon Camp Results

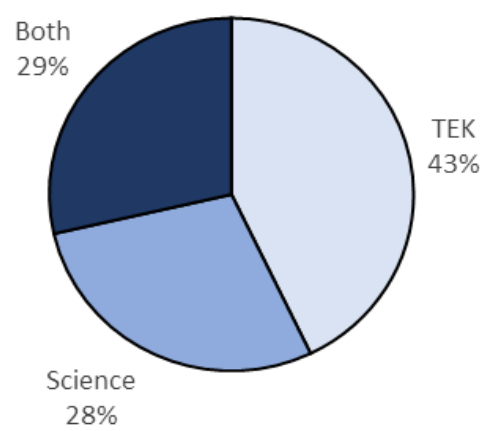


was identified as the primary knowledge base associated to the statement (43\% post survey) and "both" increasing by $8 \%$, to $29 \%$

The survey responses for Section 3 are summarized below for each camp and statement. The primary knowledge base for pre and post responses is recorded, along with the percent response.

Table 12 Summary table of changes in camp responses to Section 3 survey statements.

\begin{tabular}{|c|c|c|c|c|c|}
\hline \multirow{2}{*}{\multicolumn{2}{|c|}{ Survey Statement }} & \multicolumn{2}{|c|}{ PACE Responses } & \multicolumn{2}{|c|}{$\begin{array}{l}\text { Salmon Camp } \\
\text { Responses }\end{array}$} \\
\hline & & $\begin{array}{l}\text { Knowledge } \\
\text { Base }\end{array}$ & Percent & $\begin{array}{l}\text { Knowledge } \\
\text { Base }\end{array}$ & Percent \\
\hline \multirow{2}{*}{$\begin{array}{l}\text { Knowledge is cumulative (continually } \\
\text { built upon from prior knowledge). }\end{array}$} & Pre & Both & $60 \%$ & Science & $43 \%$ \\
\hline & Post & Both & $67 \%$ & Both & $50 \%$ \\
\hline \multirow{2}{*}{$\begin{array}{l}\text { Many people, from many generations } \\
\text { and nations, have contributed to our } \\
\text { knowledge. }\end{array}$} & Pre & TEK & $60 \%$ & Both & $64 \%$ \\
\hline & Post & TEK & $50 \%$ & $\begin{array}{l}\text { Both } \\
\text { TEK }\end{array}$ & $43 \%$ \\
\hline \multirow{2}{*}{$\begin{array}{l}\text { Different sources of knowledge can be } \\
\text { used together and benefit one another. }\end{array}$} & Pre & Both & $65 \%$ & Both & $50 \%$ \\
\hline & Post & Both & $86 \%$ & Both & $77 \%$ \\
\hline \multirow{2}{*}{$\begin{array}{l}\text { Patterns in nature can be observed } \\
\text { and measured. }\end{array}$} & Pre & Science & $45 \%$ & Science & $57 \%$ \\
\hline & Post & Both & $55 \%$ & Both & $50 \%$ \\
\hline \multirow{2}{*}{$\begin{array}{l}\text { Inconsistencies or changes are } \\
\text { considered and evaluated. }\end{array}$} & Pre & Science & $58 \%$ & $\begin{array}{l}\text { Both } \\
\text { Science }\end{array}$ & $43 \%$ \\
\hline & Post & Science & $46 \%$ & Both & $57 \%$ \\
\hline \multirow{2}{*}{$\begin{array}{l}\text { Men, women and people from } \\
\text { different backgrounds engage in } \\
\text { building knowledge. }\end{array}$} & Pre & Both & $55 \%$ & Both & $64 \%$ \\
\hline & Post & Both & $50 \%$ & Both & $64 \%$ \\
\hline \multirow{2}{*}{$\begin{array}{c}\text { Knowledge is based on observation of } \\
\text { natural patterns. }\end{array}$} & Pre & Both & $55 \%$ & Both & $50 \%$ \\
\hline & Post & TEK & $50 \%$ & Both & $64 \%$ \\
\hline \multirow{2}{*}{$\begin{array}{l}\text { Values like persistence, precision, } \\
\text { reasoning, logic, imagination, and } \\
\text { creativity are important. }\end{array}$} & Pre & Both & $60 \%$ & Both & $36 \%$ \\
\hline & Post & Both & $54 \%$ & Science & $50 \%$ \\
\hline \multirow{2}{*}{$\begin{array}{l}\text { Values like harmony, respect, } \\
\text { resiliency, interdependence, and } \\
\text { reciprocity are important. }\end{array}$} & Pre & Both & $45 \%$ & $\begin{array}{l}\text { Science } \\
\text { TEK }\end{array}$ & $36 \%$ \\
\hline & Post & TEK & $55 \%$ & TEK & $43 \%$ \\
\hline
\end{tabular}


The survey statements in Section 3 were further categorized into the NGSS NOS concepts (Science is a Way of Knowing, Scientific Knowledge Assumes an Order and Consistency in Natural Systems, Science is a Human Endeavor) and Cultural Values.

The following figures show the pre and post survey results for PACE and Salmon Camp. The data is represented in percent of participant responses for comparison between the two camps.

Table 13 Summary table of changes in camp responses for NGSS NOS concepts, compiled from survey statements.

\begin{tabular}{|c|c|c|c|c|c|}
\hline \multirow{2}{*}{\multicolumn{2}{|c|}{ NGSS NOS Concept }} & \multicolumn{2}{|c|}{ PACE Responses } & \multicolumn{2}{|c|}{ Salmon Camp Responses } \\
\hline & & $\begin{array}{l}\text { Knowledge } \\
\text { Base }\end{array}$ & Percent & Knowledge Base & Percent \\
\hline \multirow{2}{*}{$\begin{array}{c}\text { Science is a Way of } \\
\text { Knowing }\end{array}$} & Pre & Both & $53 \%$ & Both & $50 \%$ \\
\hline & Post & Both & $66 \%$ & Both & $56 \%$ \\
\hline \multirow{2}{*}{$\begin{array}{c}\text { Scientific Knowledge } \\
\text { Assumes an Order and } \\
\text { Consistency in Natural } \\
\text { Systems }\end{array}$} & Pre & Both & $37 \%$ & Science & $43 \%$ \\
\hline & Post & Both & $42 \%$ & Both & $57 \%$ \\
\hline \multirow{2}{*}{$\begin{array}{l}\text { Science is a Human } \\
\text { Endeavor }\end{array}$} & Pre & Both & $53 \%$ & Both & $40 \%$ \\
\hline & Post & Both & $47 \%$ & Both & $43 \%$ \\
\hline
\end{tabular}




\section{Survey Section 3 Results for NGSS NOS Concept: Science is a Way of}

\section{Knowing}

The responses for each camp were similar although little change was observed comparing pre and post survey responses. PACE responses favored "both" knowledge bases as associated to the statement for both pre (53\%) and post (66\%) survey responses. Responses indicating "TEK" as the knowledge base was indicated by $37 \%$ of participants (pre) and 22\% (post). For Salmon Camp, "both” was also highly favored, 50\% pre

Figure 38 Result details for NGSS NOS concept "Science is a way of knowing."
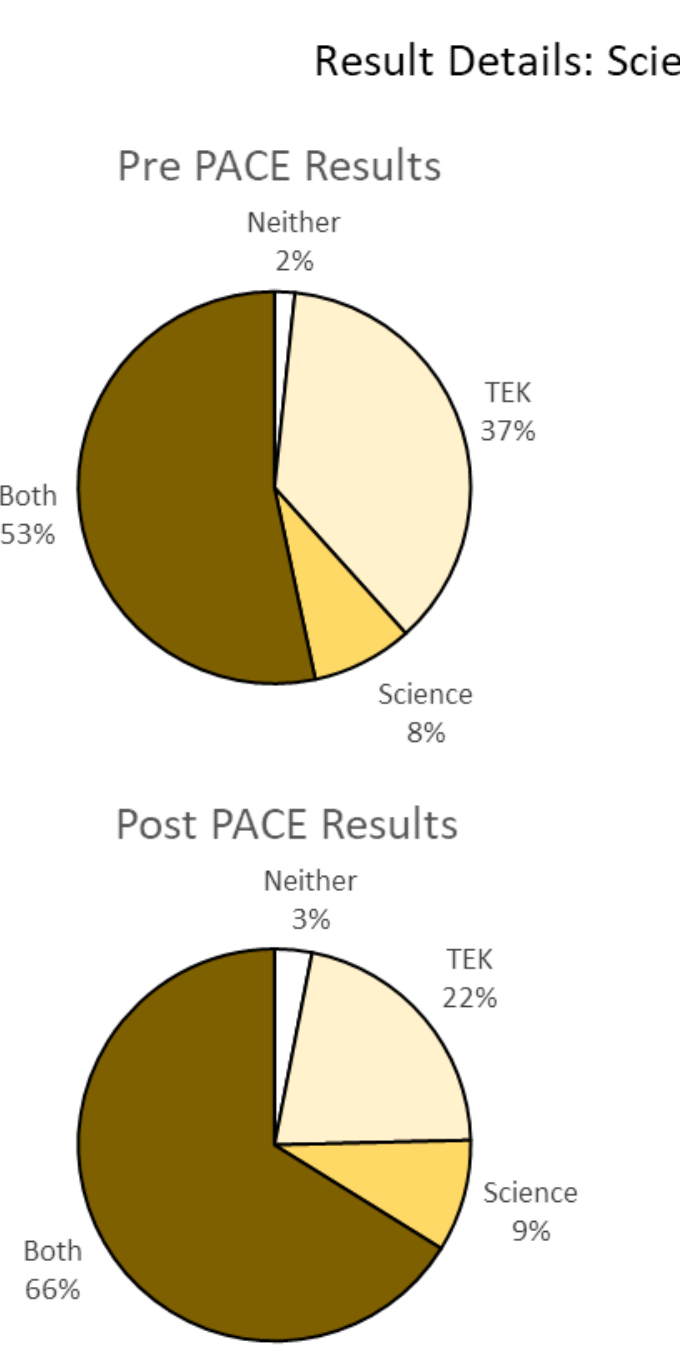

Pre Salmon Camp Results

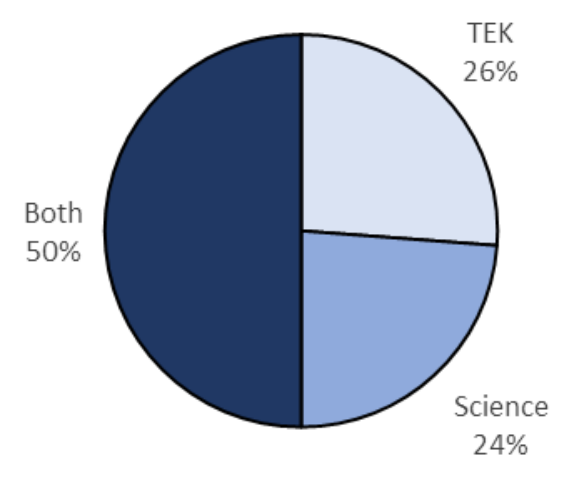

\section{Post Salmon Camp Results}

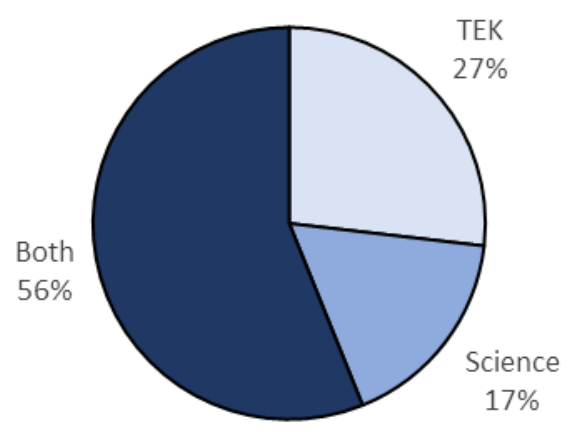


survey responses and 56\% post survey responses. Salmon Camp responses for "TEK" increased by only $1 \%$.

\section{Survey Section 3 Results for NGSS NOS Concept: Scientific Knowledge}

\section{Assumes an Order and Consistency in Natural Systems}

Responses for the two camps varied. PACE responses had little change with a distribution of $42 \%$ (both), 32\% (science), and 23\% (TEK) for post survey responses.

Figure 39 Result details for NGSS NOS concept "Scientific knowledge assumes an order and consistency in natural systems."

Result Details: Scientific knowledge assumes an order and consistency in natural systems

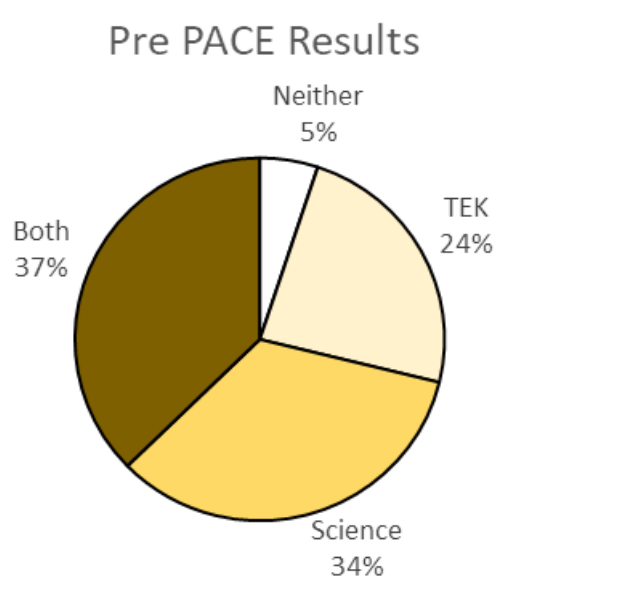

Pre Salmon Camp Results
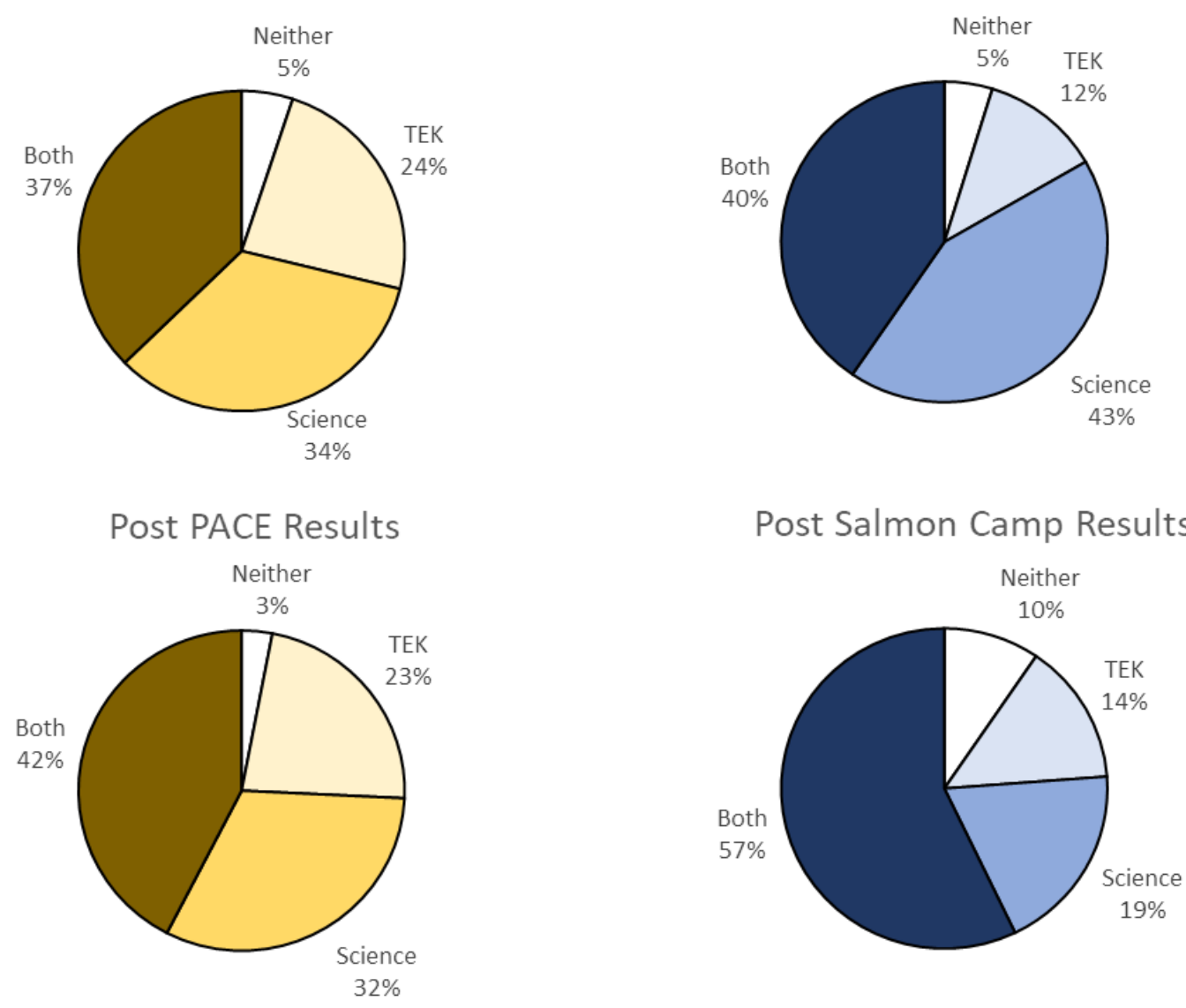

\section{Post Salmon Camp Results}

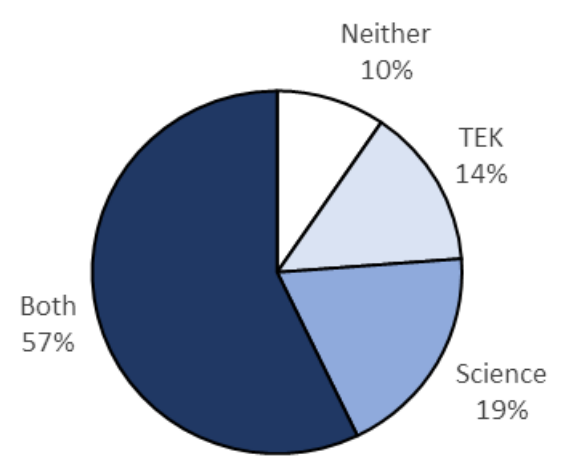


The greatest change for PACE was 5\% increase in responses for "both". Salmon Camp results exhibited a greater change from pre and post surveys, with a $17 \%$ increase for "both" responses. In comparison, Salmon Camp responses favored "both" 15\% more than PACE responses, although more responses for Salmon Camp claimed "neither" at $10 \%$ and PACE only $3 \%$. 


\section{Survey Section 3 Results for NGSS NOS Concept: Science is a Human}

\section{Endeavor}

Pre and post responses exhibited little change, although the camps had some variation. PACE results favored "both" at 53\% and $47 \%$ for pre and post surveys, respectively. "Science" responses had no change, while the greatest change was the $8 \%$ increase in "TEK" responses. Salmon Camp results also favored "both" with only a 3\% increase to $43 \%$ in post survey responses. Responses for "neither" were reduced by $7 \%$.

Figure 40 Result details for NGSS NOS concept "Science is a human endeavor."

\section{Result Details: Science is a human endeavor}
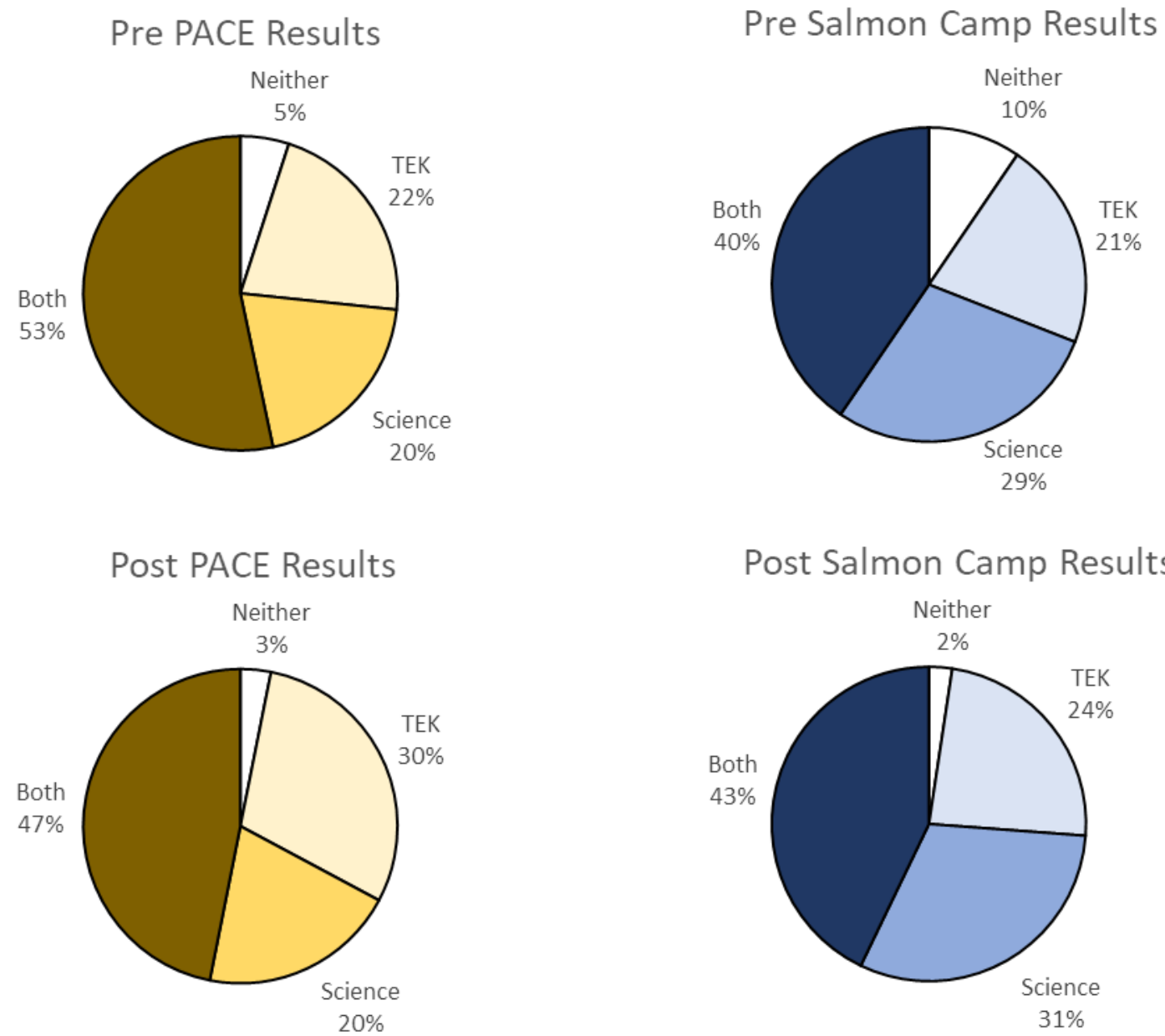

\section{Post Salmon Camp Results}

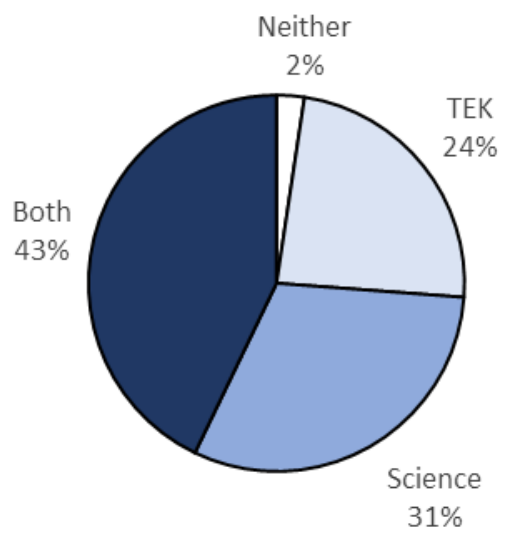




\section{Explicit NOS Instruction in Camp Activities and Portfolios}

Camp activities and teaching methods were evaluated for their demonstration of Version 1 and Version 2 explicit teaching methods of the Nature of Science. Camp activities were scored on a 0 - 10 scale, which is derived from the Duschl and Grandy (2013) table referenced in the literature review (table 2). For each version of explicit teaching, there are ten qualities described, the score reflects how many of those qualities the camp activities and teaching methods exhibited.

Each camp had portfolio entries designed to fit with the flow of the camp agenda; PACE had daily worksheets and Salmon Camp had a poster. Instructions for PACE portfolios requested three keywords for each entry, while instructions for Salmon Camp portfolios requested one keyword. Portfolio ratings were determined by dividing the total score by the total entries (e.g. total score $24 /$ total entries $21=1.14$ rating). The higher the number, the better rating with a range between $0-2$ (e.g. a perfect score would be 48 total score/ 24 total entries; this means every portfolio entry scored 2). Each portfolio entry was evaluated using the scoring rubric (table 11), which identifies the keyword(s) used, a score for the demonstrated understanding/use of the keyword, and the knowledge base indicated. The table below provides information on collected portfolio entries. For each day, keywords were evaluated and scored which is displayed in a table for each day. Further, the data for the keywords is compiled into the NGSS NOS concepts for a broader understanding.

Table 14 Summary table of portfolio entries for each camp.

\begin{tabular}{|l|c|c|c|c|}
\hline \multicolumn{1}{|c|}{ Camp } & Camp Participants & $\begin{array}{c}\text { Portfolio Entry } \\
\text { Days }\end{array}$ & Total Keywords & $\begin{array}{c}\text { Average } \\
\text { Portfolio Rating }\end{array}$ \\
\hline PACE & 22 & 7 & $343^{*}$ & 1.02 \\
\hline $\begin{array}{l}\text { Salmon } \\
\text { Camp }\end{array}$ & 14 & 4 & $61^{*}$ & 1.41 \\
\hline
\end{tabular}




\section{PACE Instruction and Portfolios}

There were eleven PACE camp activities evaluated for NOS explicit instruction. For Version 1

the average score was 2.5 and for Version 2, the average score was 4.6.

Table 15 Evaluations of PACE camp activities and teaching methods for NOS explicit instruction.

\begin{tabular}{|c|c|c|c|c|}
\hline Day & Topic & Teaching Methods & Version 1 & Version 2 \\
\hline 1 & $\begin{array}{l}\text { TEK: NPT history; cultural } \\
\text { identity }\end{array}$ & $\begin{array}{l}\text { Reflective activities; multimedia } \\
\text { (videos) }\end{array}$ & 2 & 2 \\
\hline 2 & $\begin{array}{l}\text { Computer programming; } \\
\text { software vs. hardware; modeling } \\
\text { and simulation; artificial } \\
\text { intelligence and robots; Scratch } \\
\text { computer program }\end{array}$ & $\begin{array}{l}\text { Robot demonstration; hands-on } \\
\text { exploration (programming) }\end{array}$ & 2 & 7 \\
\hline \multirow[b]{2}{*}{3} & $\begin{array}{l}\text { Soil biology; biodiversity; fungi; } \\
\text { earthworms; hissing cockroaches }\end{array}$ & $\begin{array}{l}\text { PowerPoint presentation; hands- } \\
\text { on exploration (wet/dry soil } \\
\text { properties; handling insects) }\end{array}$ & 6 & 1 \\
\hline & $\begin{array}{l}\text { TEK: Cultural significance to } \\
\text { landscapes; Bio-Control agents } \\
\text { (insects); noxious weeds; land } \\
\text { management throughout the NW }\end{array}$ & $\begin{array}{l}\text { Multimedia presentation (video); } \\
\text { hands-on exploration (handling } \\
\text { insects); guided tour of } \\
\text { greenhouse }\end{array}$ & 3 & 7 \\
\hline 4 & $\begin{array}{l}\text { TEK: Cultural significance and } \\
\text { history of NPT and fish species } \\
\text { (salmon, lamprey). Salmon life } \\
\text { cycle; hatchery production; } \\
\text { facilities; and research. }\end{array}$ & $\begin{array}{l}\text { Guided tour of hatchery; hands- } \\
\text { on activity (feeding fish) }\end{array}$ & 2 & 3 \\
\hline \multirow[b]{2}{*}{5} & $\begin{array}{l}\text { Renewable energy; wind mills- } \\
\text { history, types, design, } \\
\text { limitations; design } \\
\text { challenge/competition }\end{array}$ & $\begin{array}{l}\text { Presentation; hands-on } \\
\text { exploration (windmill design } \\
\text { challenge) }\end{array}$ & 1 & 6 \\
\hline & $\begin{array}{l}\text { Scientific method: making } \\
\text { observations; recognizing } \\
\text { patterns; identifying anomalies; } \\
\text { generating a research question; } \\
\text { and developing a research plan } \\
\text { focusing on plant species found } \\
\text { in the local community garden }\end{array}$ & $\begin{array}{l}\text { Guided observations; group } \\
\text { discussion/ talking circle; self- } \\
\text { reflection; group evaluation of } \\
\text { individual research plans }\end{array}$ & 1 & 6 \\
\hline
\end{tabular}


Table 15 Continued

\begin{tabular}{|c|c|c|c|c|}
\hline & $\begin{array}{l}\text { TEK: Research in fish sciences; } \\
\text { fish anatomy and health; } \\
\text { traditional fishing practices }\end{array}$ & $\begin{array}{l}\text { PowerPoint presentation and } \\
\text { guided observations; hands-on } \\
\text { exploration (fish dissection) }\end{array}$ & 3 & 3 \\
\hline 0 & $\begin{array}{l}\text { TEK: Research in wildlife } \\
\text { sciences; tracking of wildlife } \\
\text { populations with radio collars; } \\
\text { tagging techniques; traditional } \\
\text { hunting locations and practices }\end{array}$ & $\begin{array}{l}\text { Hands-on exploration (dart gun } \\
\text { tagging); multimedia (video) }\end{array}$ & 3 & 5 \\
\hline 7 & $\begin{array}{l}\text { Video game development; } \\
\text { computer science careers; using } \\
\text { technology in biology and other } \\
\text { research }\end{array}$ & $\begin{array}{l}\text { Hands-on exploration (guided } \\
\text { computer gaming and character } \\
\text { design and development) }\end{array}$ & 3 & 6 \\
\hline 8 & $\begin{array}{l}\text { Hanford Nuclear Waste Site; } \\
\text { groundwater and soil } \\
\text { contamination/ protection; rock } \\
\text { cycle; types; and properties; } \\
\text { storm water management }\end{array}$ & $\begin{array}{l}\text { Presentation; hands-on } \\
\text { exploration (different rock types } \\
\text { and properties) }\end{array}$ & 2 & 5 \\
\hline
\end{tabular}




\section{PACE Day 2 Portfolio Entries}

The camp activities for this day was focused on computer science and participants learned about computer components (e.g. software, hardware) and how to use Scratch computer programming. A quarter of portfolio entries identified the keyword "technology", while $22 \%$ described "creativity" and $15 \%$ included "changes". Being the first day of portfolio entries, $47 \%$ of the responses scored zero. The majority (53\%) of responses fell within the NOS concept "Science is a Human Endeavor". Participants identified the knowledge as "both" at $54 \%$ and $23 \%$ as "science".

Figure 41 PACE Day 2 keywords and score for portfolio entries.
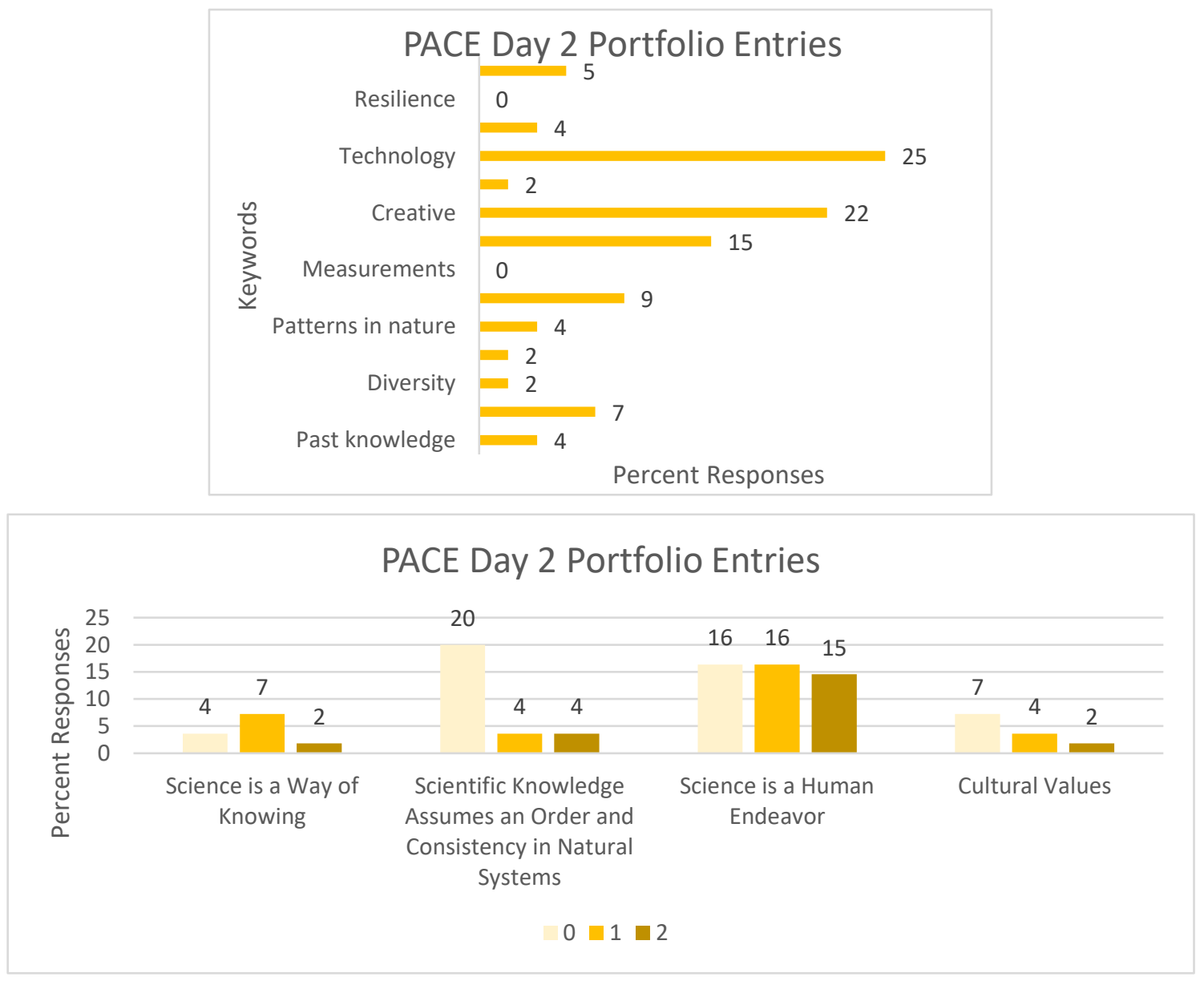
PACE Day 3 Portfolio Entries

The camp activities for this day was focused on soil science, bio-control agents, and invasive/noxious weeds. All keywords were used in portfolio entries to varying extents. "Changes" was the dominant keyword identified at $16 \%$ of the total responses, followed by "measurements" and "observations" both at 14\%. "Scientific Knowledge Assumes an Order and Consistency in Natural Systems" comprised of 53\% of the portfolio entries for this day, with a score of one and two at $23 \%$ each. "Science" was identified as the knowledge base for $57 \%$ of responses and $35 \%$ for "both".

Figure 42 PACE Day 3 keywords and score for portfolio entries.
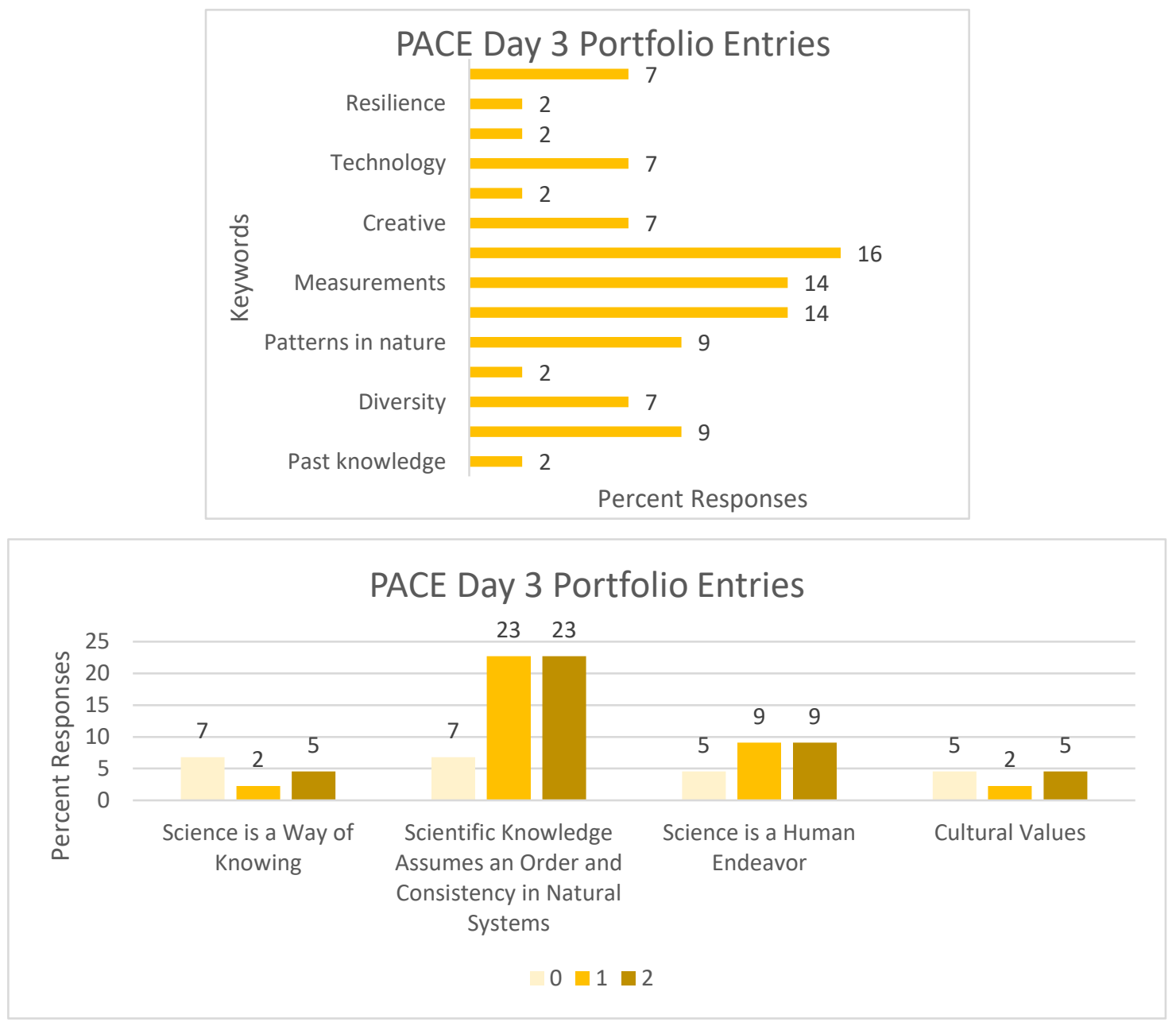


\section{PACE Day 4 Portfolio Entries}

The camp activities for this day was focused on tribal fisheries, the salmon life cycle, and a tour of the NPT Dworshak National Fish Hatchery. All keywords were used in portfolio entries to varying extents. "Changes" was the dominant keyword identified at $16 \%$ of the total responses, followed by "observation" and "patterns in nature" both at 14\%. "Scientific Knowledge Assumes an Order and Consistency in Natural Systems" comprised of $55 \%$ of the portfolio entries for this day, with $39 \%$ scoring a 2 , relating camp activities to NOS concepts. "Both" knowledge bases were identified for $37 \%$ of responses and $27 \%$ for "science".

Figure 43 PACE Day 4 keywords and score for portfolio entries.

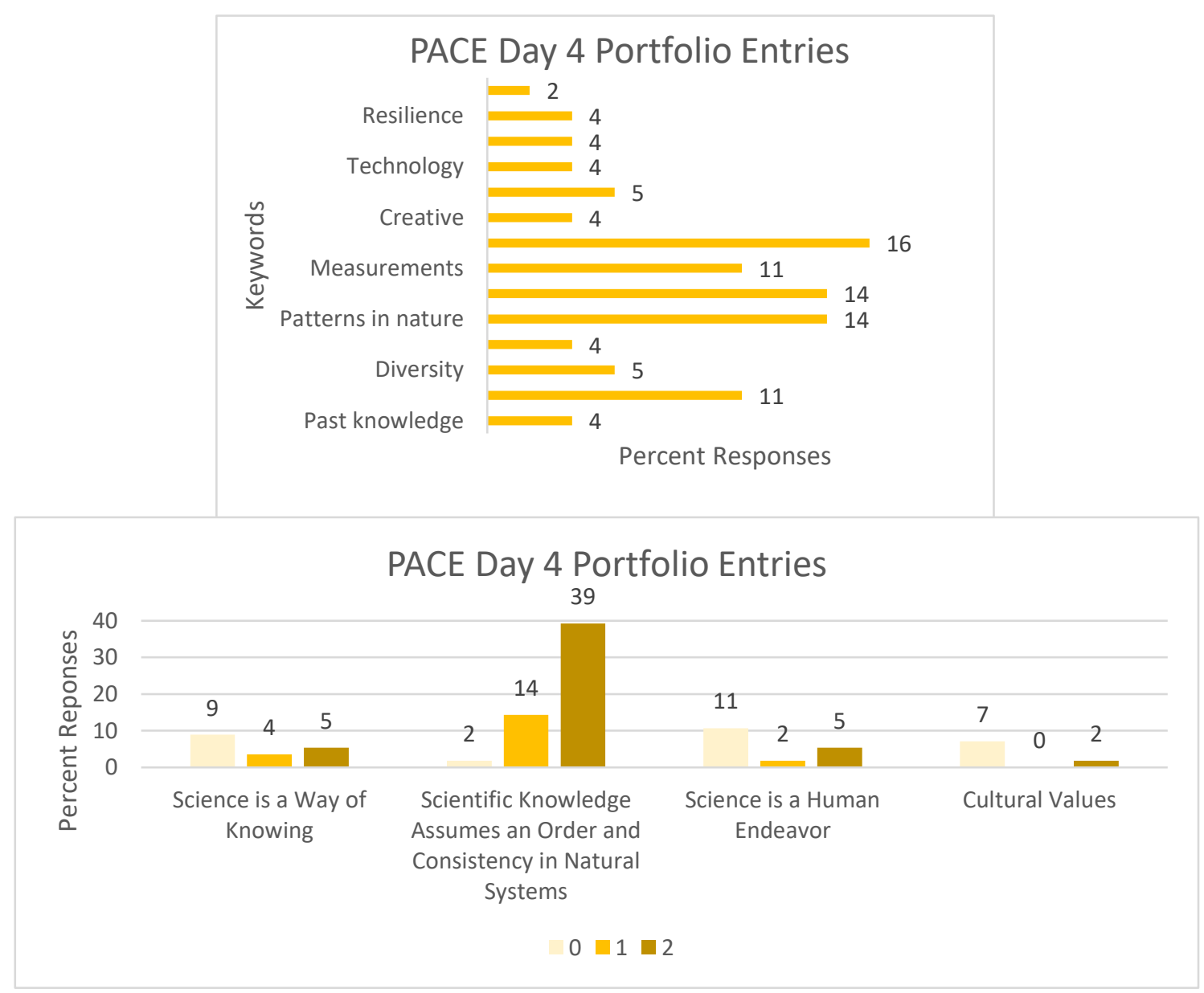




\section{PACE Day 5 Portfolio Entries}

The camp activities for this day was focused on model windmill construction, aerodynamics, and the scientific method. "Creativity" was mentioned in $21 \%$ of portfolio entries, describing how they had to be creative to build different windmill models and $19 \%$ with "observations", describing the scientific method activities of observing plant in the local community garden. Responses related to NOS concepts was broadly distributed, and 36\% were scored zero, 23\% scored one, and 32\% scored two. "Both" knowledge bases were identified for $55 \%$ of the responses and $23 \%$ for "science".

Figure 44 PACE Day 5 keywords and score for portfolio entries.
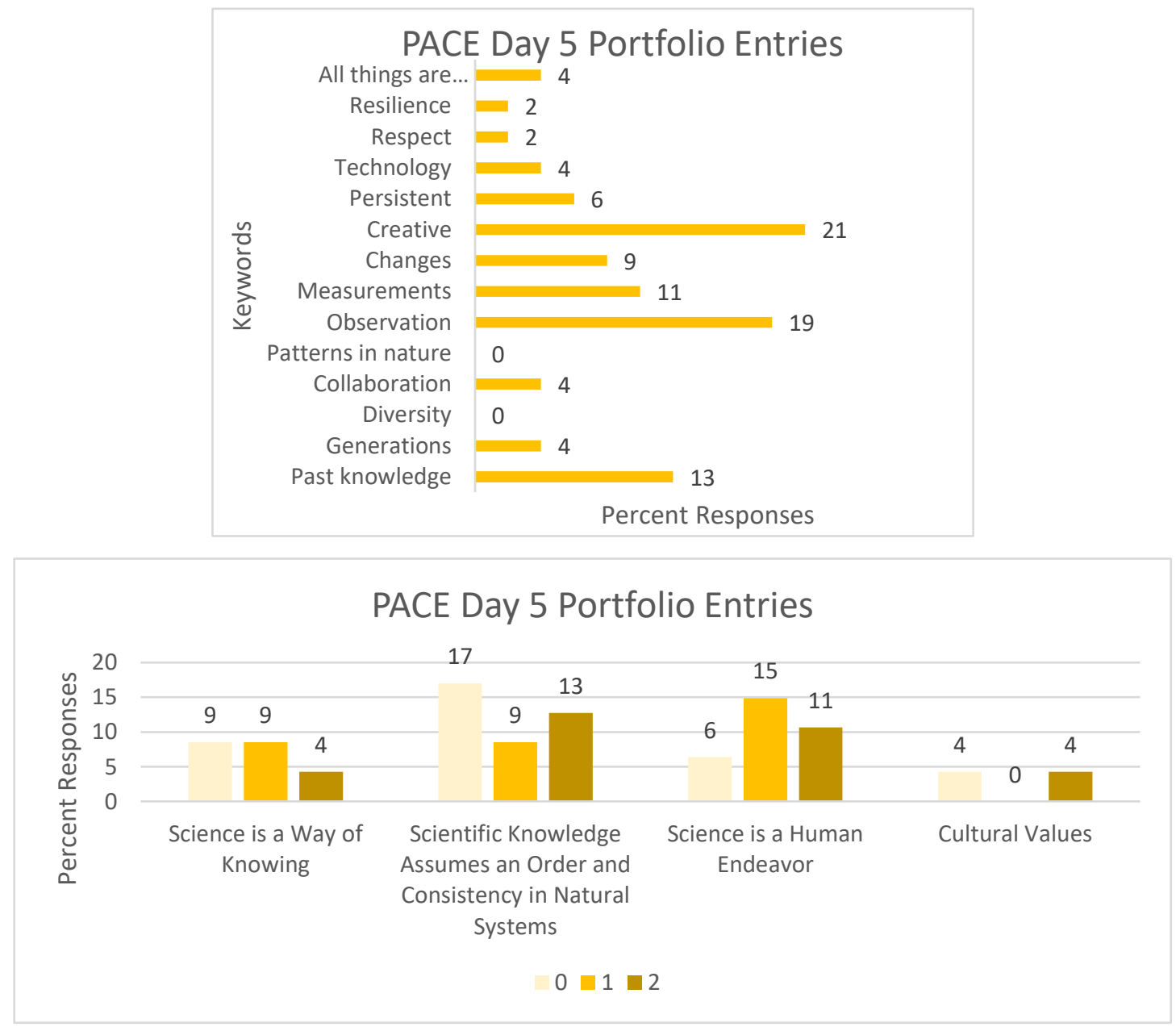


\section{PACE Day 6 Portfolio Entries}

The camp activities for this day was focused on fish and wildlife biology, including fish dissection and shooting euthanizing dart guns. "Observation" was mentioned in $21 \%$ of portfolio entries and "patterns in nature" in $19 \%$. "Scientific Knowledge Assumes an Order and Consistency in Natural Systems" was the dominant NOS concept mentioned with $60 \%$ of the responses, of which half scored 2 and a third scored 1. "Both" knowledge bases were indicated for $48 \%$ of the responses and $34 \%$ for "science".

Figure 45 PACE Day 6 keywords and score for portfolio entries.
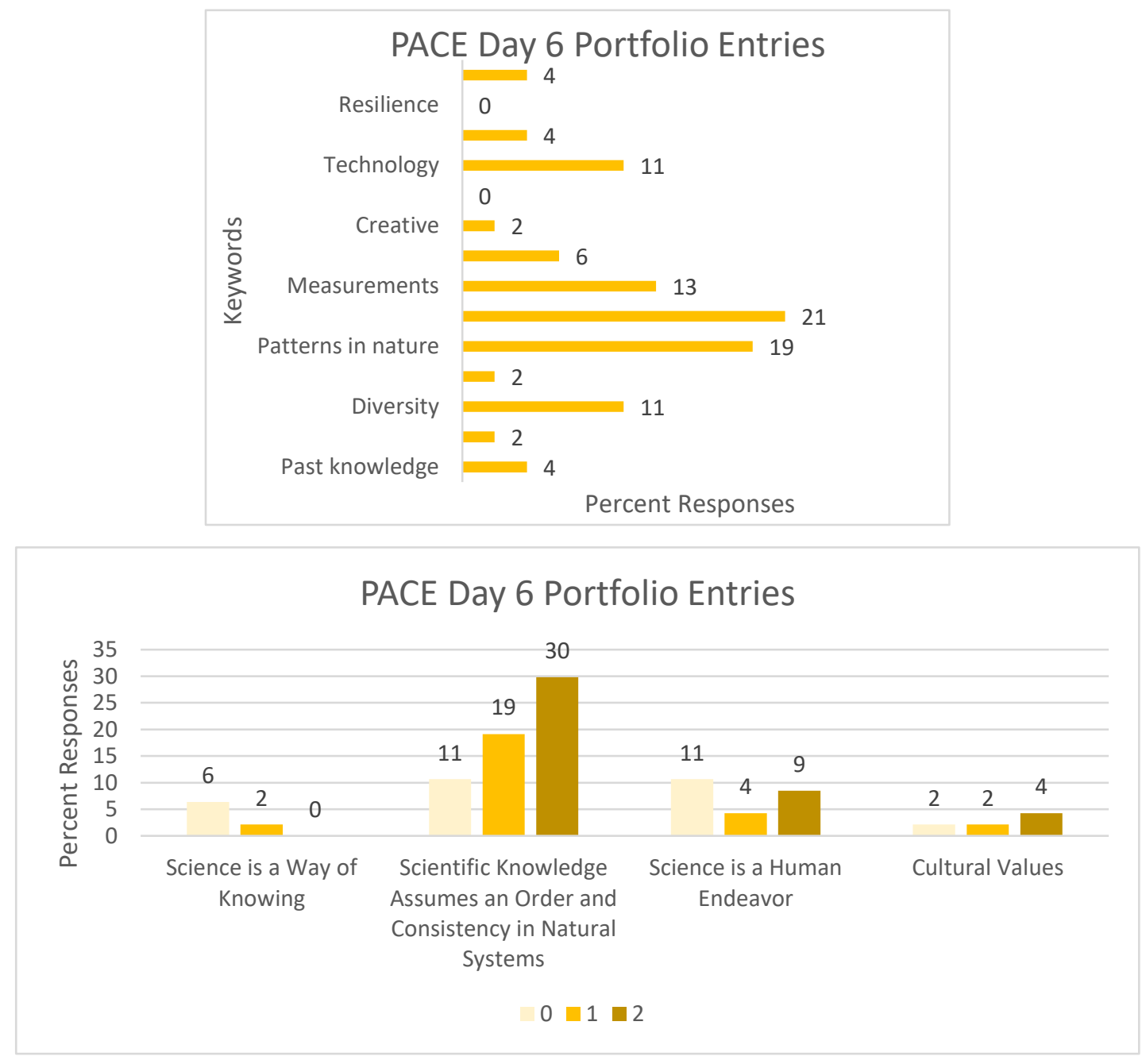


\section{PACE Day 7 Portfolio Entries}

The camp activities for this day was focused on video game development and research using technology. "Creativity" was mentioned in $24 \%$ of portfolio entries, and $18 \%$ with "technology". Responses related to NOS concepts was mostly comprised of "Science is a Human Endeavor" keywords (55\%), of which 27\% scored two. "Both" knowledge bases were identified for $44 \%$ of responses and $36 \%$ for "science".

Figure 46 PACE Day 7 keywords and score for portfolio entries.

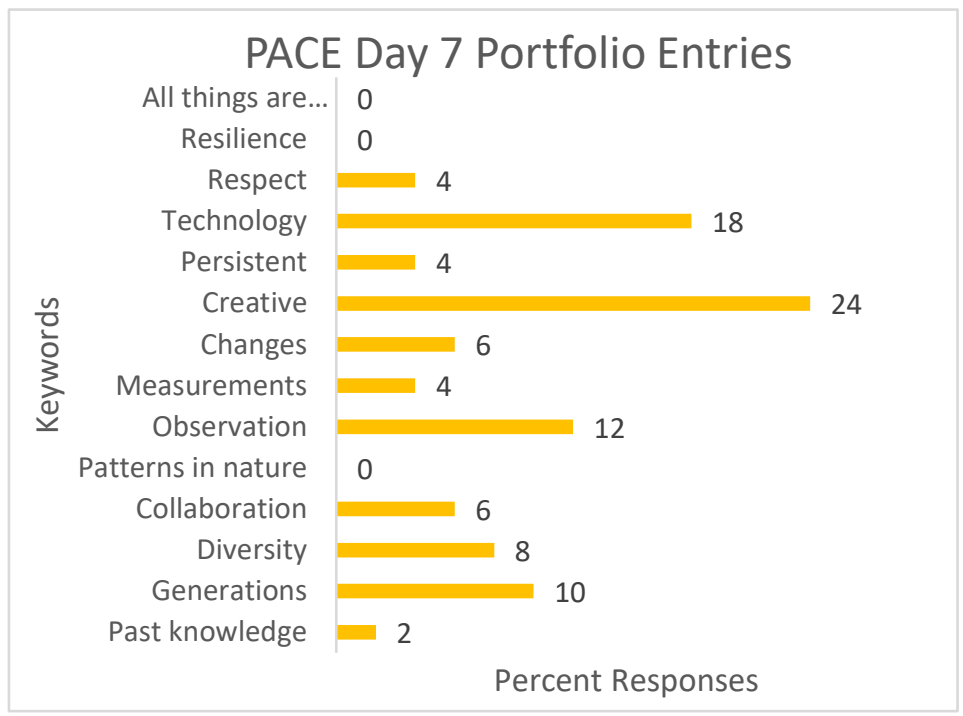

PACE Day 7 Portfolio Entries

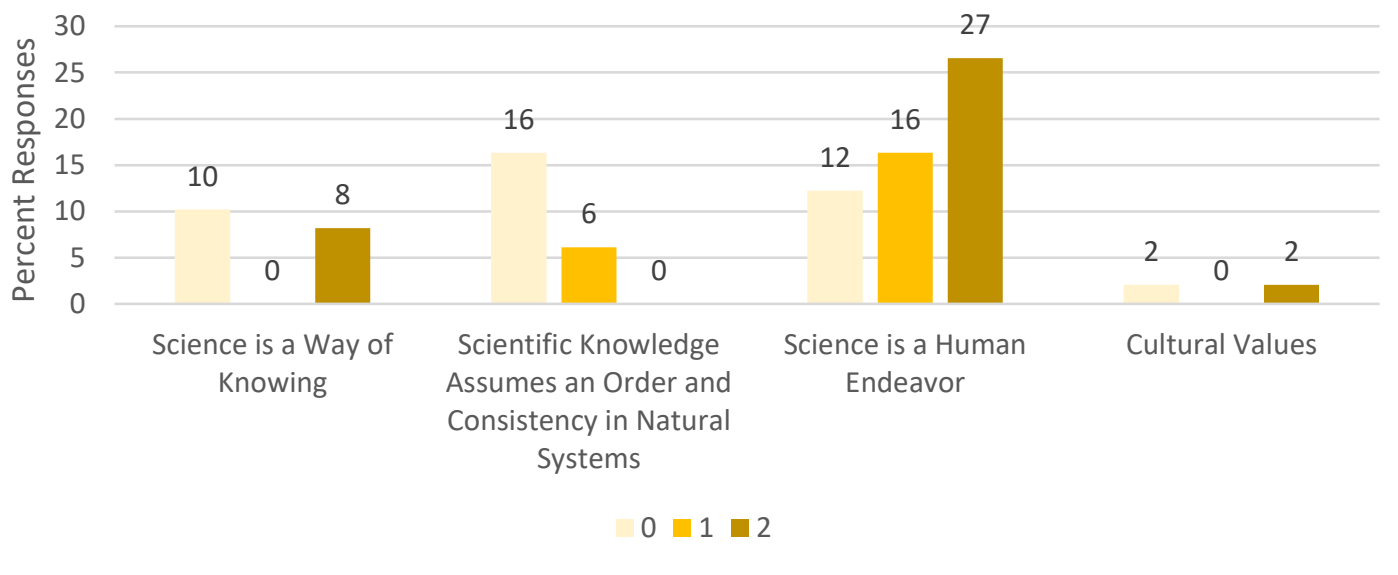




\section{PACE Day 8 Portfolio Entries}

The camp activities for this day was focused on geology, groundwater and soil contamination, and the Hanford Nuclear Waste Site. "Observations" were mentioned in $18 \%$ of portfolio entries, while "past knowledge" and "changes" were mentioned at $13 \%$ and $11 \%$, respectively. Responses related to NOS concepts was broadly distributed, and $36 \%$ scoring zero, $33 \%$ scoring one, and $31 \%$ scoring two. "Both" knowledge bases were indicated in responses at $44 \%$ and $36 \%$ for "science".

Figure 47 PACE Day 8 keywords and score for portfolio entries.
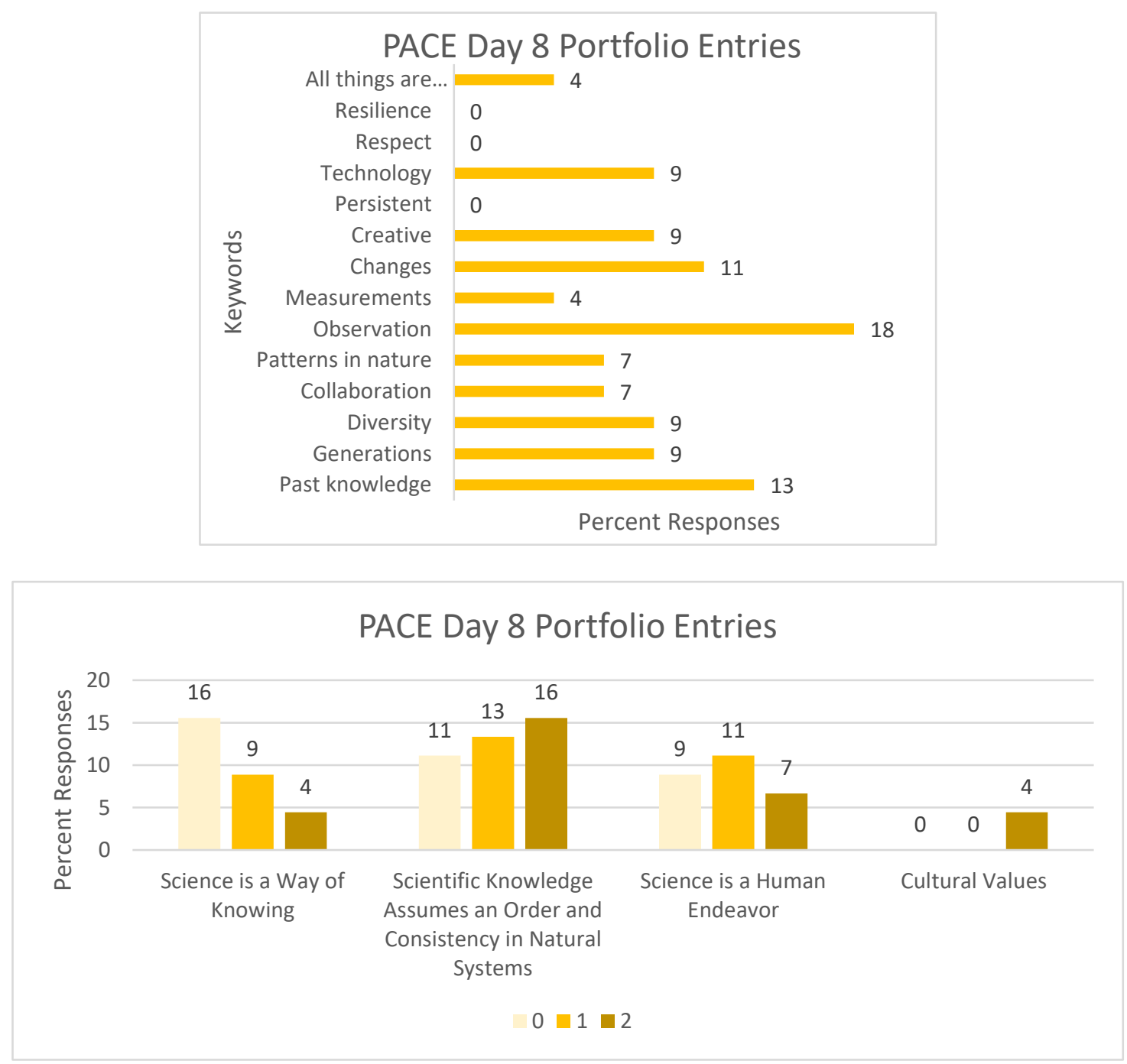


\section{$\underline{\text { Salmon Camp Instruction and Portfolios }}$}

There were eleven Salmon Camp activities evaluated NOS explicit instruction. For Version 1 the average score was 1.1 and for Version 2, the average score was 6.4.

Table 16 Evaluation of Salmon Camp activities and teaching methods for NOS explicit instruction.

\begin{tabular}{|c|c|c|c|c|}
\hline Day & Topic & Teaching Methods & Version 1 & Version 2 \\
\hline 1 & $\begin{array}{l}\text { Tribal history and culture; sweat } \\
\text { ceremony; and team building }\end{array}$ & $\begin{array}{l}\text { Guided participation in } \\
\text { traditional teachings and } \\
\text { songs; hands-on }\end{array}$ & $\mathrm{n} / \mathrm{a}$ & $\mathrm{n} / \mathrm{a}$ \\
\hline \multirow{4}{*}{2} & $\begin{array}{l}\text { Lamprey life cycle; tribal hatchery } \\
\& \text { restoration efforts }\end{array}$ & $\begin{array}{l}\text { Guided tour; hands-on } \\
\text { (viewing tanks and fish } \\
\text { feeding; microscope access) }\end{array}$ & 1 & 7 \\
\hline & $\begin{array}{l}\text { TEK: Cultural significance and use } \\
\text { of mussels; restoration; ecosystem } \\
\text { services; threats to species; tribal } \\
\text { treaties }\end{array}$ & $\begin{array}{l}\text { Hands-on exploration } \\
\text { (identifying species } \\
\text { (invasive/native, } \\
\text { male/female; dissection) }\end{array}$ & 1 & 8 \\
\hline & $\begin{array}{l}\text { TEK: Cultural significance and use } \\
\text { of fish; fish habitat (4C: complex, } \\
\text { cold, connected, clean); } \\
\text { restoration; macroinvertebrate } \\
\text { sampling; water quality }\end{array}$ & $\begin{array}{l}\text { Poster presentation; guided } \\
\text { participation; handouts } \\
\text { (macro ID); hands-on } \\
\text { exploration (macro } \\
\text { sampling) }\end{array}$ & 1 & 9 \\
\hline & $\begin{array}{l}\text { TEK: Cultural significance and use } \\
\text { of traditional plants; identification } \\
\text { of and connections to fish; } \\
\text { ecosystem connections }\end{array}$ & $\begin{array}{l}\text { Guided tour; fish hatchery } \\
\text { viewing }\end{array}$ & 0 & 8 \\
\hline \multirow{3}{*}{3} & $\begin{array}{l}\text { TEK: Cultural significance and use } \\
\text { of water and place } \\
\text { (ethnogeography); traditional } \\
\text { stories; cultural site history; } \\
\text { importance of tribal identity; } \\
\text { responsibility of future generations }\end{array}$ & $\begin{array}{l}\text { Oral presentations and } \\
\text { storytelling }\end{array}$ & 2 & 4 \\
\hline & $\begin{array}{l}\text { TEK: Cultural site history } \\
\text { (ethnogeography, } \\
\text { biotype/landscape) and resource } \\
\text { procurement; water blessing; } \\
\text { cultural significance and use of } \\
\text { water and fish; ecosystem threats }\end{array}$ & $\begin{array}{l}\text { Oral presentation and } \\
\text { traditional song }\end{array}$ & 2 & 4 \\
\hline & $\begin{array}{l}\text { Dam construction; Columbia River } \\
\text { history; fish species and life } \\
\text { cycles; fish passages; viewing } \\
\text { windows; fish monitoring/count; } \\
\text { fish hatchery }\end{array}$ & $\begin{array}{l}\text { Educational kiosks; oral } \\
\text { presentation; handouts }\end{array}$ & 2 & 6 \\
\hline
\end{tabular}




\begin{tabular}{|c|c|c|c|c|}
\hline & $\begin{array}{l}\text { TEK: Cultural significance and use } \\
\text { of water, fish, and resource } \\
\text { procurement; traditional fishing; } \\
\text { tribal sovereignty and treaty rights; } \\
\text { family history (ethnogeography); } \\
\text { seasonal round }\end{array}$ & $\begin{array}{l}\text { Oral presentation; } \\
\text { scaffold/dipnet fishing } \\
\text { demonstration }\end{array}$ & 1 & 6 \\
\hline & $\begin{array}{l}\text { TEK: Cultural significance and use } \\
\text { of fish, resource procurement, and } \\
\text { ethnogeography; tribal sovereignty } \\
\text { and treaty rights; family history; } \\
\text { regional politics; entrepreneurship }\end{array}$ & Site tour & 2 & 4 \\
\hline & $\begin{array}{l}\text { TEK: Cultural significance and use } \\
\text { of fish and resource procurement, } \\
\text { and ethnogeography; traditional } \\
\text { fishing techniques; family history; } \\
\text { tribal sovereignty and treaty rights; } \\
\text { traditional/modern law; seasonal } \\
\text { round }\end{array}$ & $\begin{array}{l}\text { Demonstration of fishing } \\
\text { techniques and equipment }\end{array}$ & 0 & 6 \\
\hline 4 & $\begin{array}{l}\text { TEK Cultural significance of } \\
\text { landscape, climate, and } \\
\text { ethnogeography; habitat } \\
\text { restoration; invasive plants and } \\
\text { weed management; water quality; } \\
\text { field data collection (vegetation } \\
\text { transects; water levels; photo } \\
\text { points) }\end{array}$ & $\begin{array}{l}\text { Demonstration; hands-on } \\
\text { exploration; service learning } \\
\text { project }\end{array}$ & 0 & 8 \\
\hline \multirow{3}{*}{5} & College Staff & Campus tour & $\mathrm{n} / \mathrm{a}$ & $\mathrm{n} / \mathrm{a}$ \\
\hline & Academic Journey & Personal narrative & $\mathrm{n} / \mathrm{a}$ & $\mathrm{n} / \mathrm{a}$ \\
\hline & $\begin{array}{l}\text { Traditional Meal (food preparation } \\
\text { and serving) }\end{array}$ & $\begin{array}{l}\text { Hands-on; service learning } \\
\text { project }\end{array}$ & $\mathrm{n} / \mathrm{a}$ & $\mathrm{n} / \mathrm{a}$ \\
\hline
\end{tabular}


Salmon Camp Day 2 Portfolio Entries

The camp activities for this day included visiting a research lab on a college campus, visiting a restoration site, and learning about water quality sampling and traditional plants. "Changes" and "observations" were the primary keywords used to describe the day's activities each at 22\%. "Past knowledge" was mentioned in $17 \%$ of portfolio entries. No portfolio entries received a score of zero. "Scientific Knowledge Assumes an Order and Consistency in Natural Systems" accounted for 57\% of the associated keywords used, with 50\% scoring two. The knowledge bases identified were 23\% "TEK", 47\% "science", and 31\% "both".

Figure 48 Salmon Camp Day 2 keywords and score for portfolio entries.

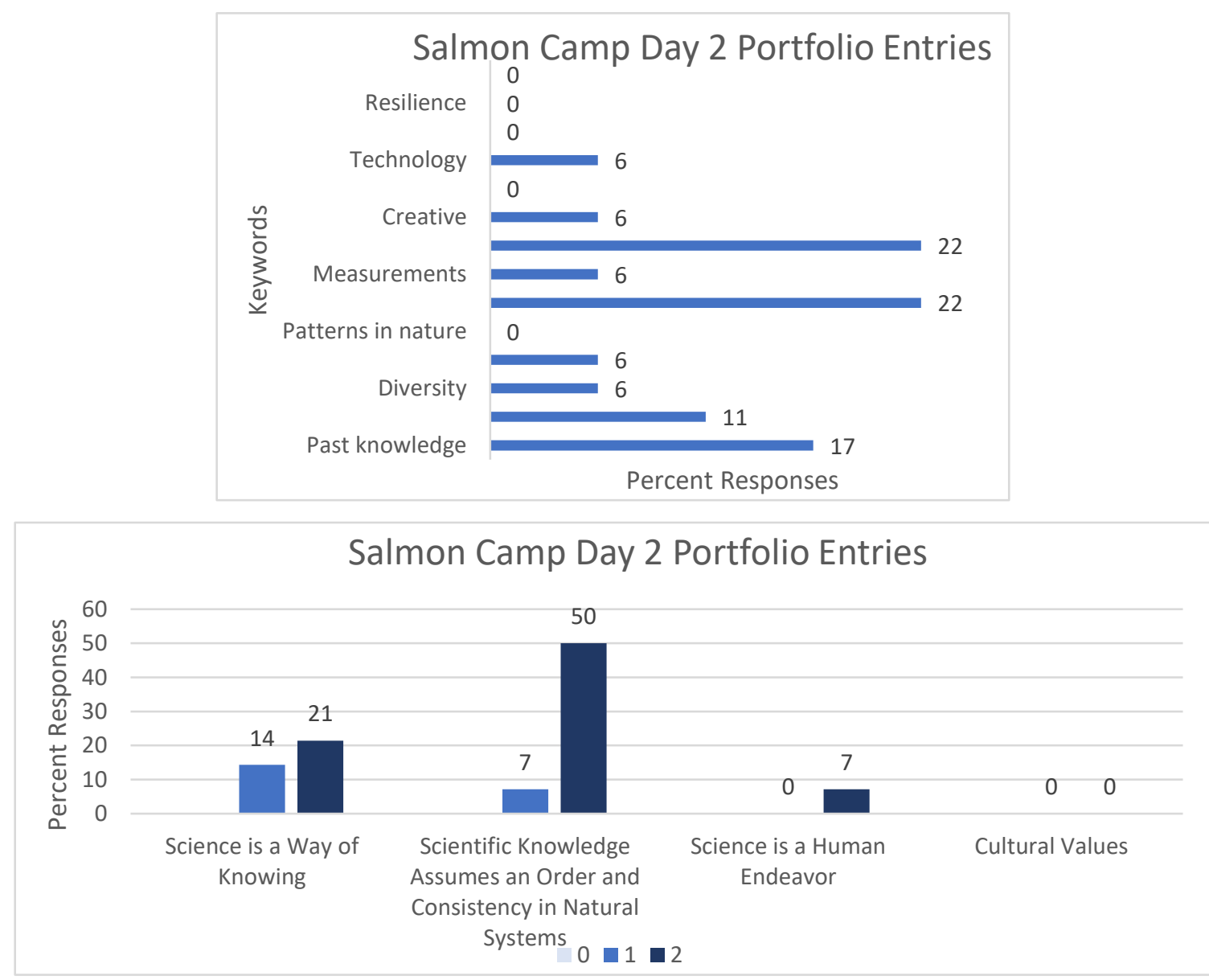




\section{Salmon Camp Day 3 Portfolio Entries}

The camp activities for this day included visiting cultural fishing sites and

Bonneville Dam, and listening to elders and tribal fishermen/women. "Respect" was a

Figure 49 Salmon Camp Day 3 keywords and score for portfolio entries.
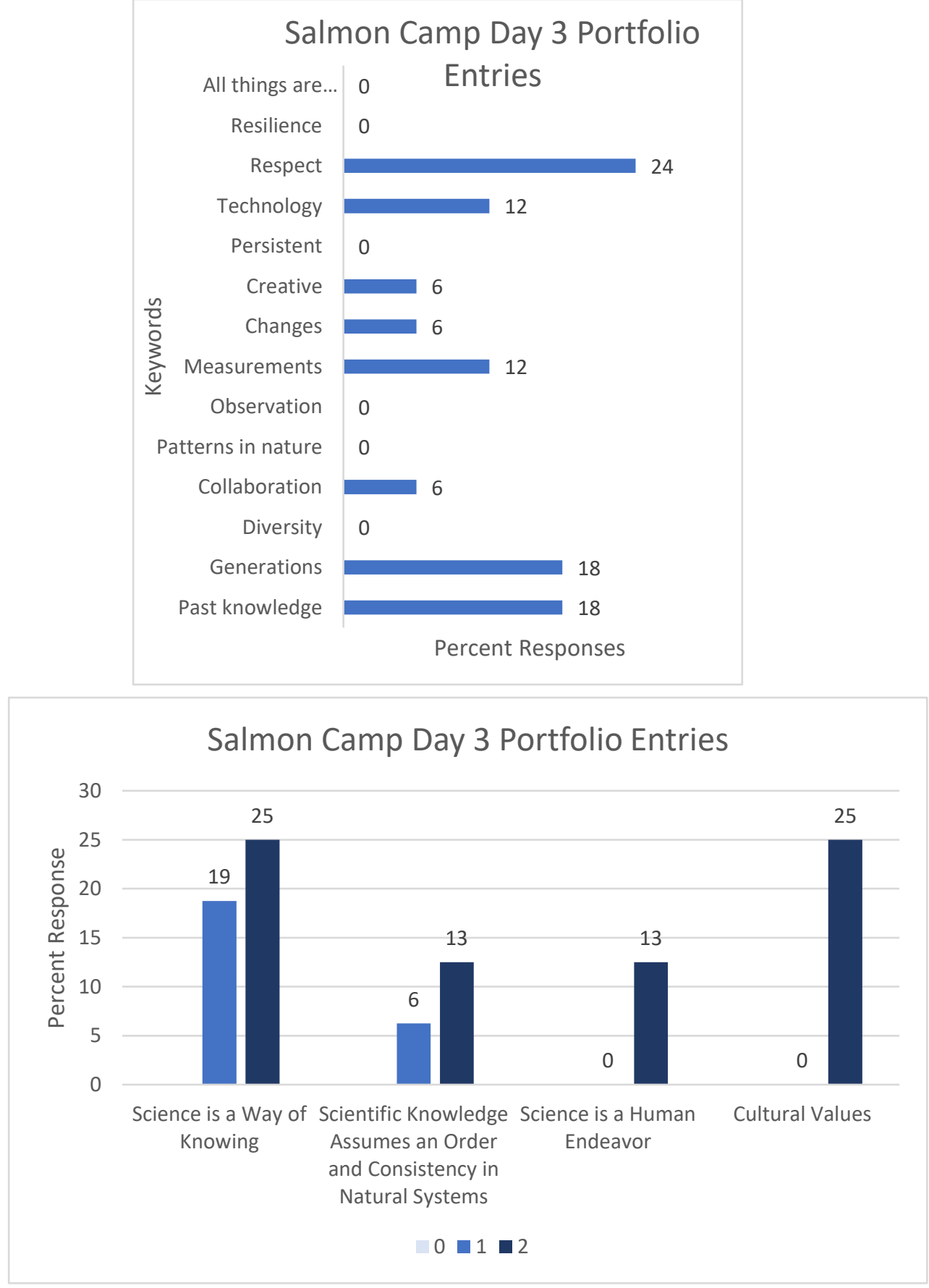
prominent keyword used to describe the day with $24 \%$ of the responses. "Generations" and "past knowledge" were used in $18 \%$ of responses each. No portfolio entries received a score of zero. "Science is a Way of Knowing" accounted for 34\% of the associated keywords used, with $25 \%$ scoring 2 . Overall $76 \%$ of responses scored 2 . A quarter of responses were associated to "Cultural Values" which is reflected in the $62 \%$ characterization of knowledge as "TEK". 


\section{Salmon Camp Day 4 Portfolio Entries}

The camp activities for this day included visiting a restoration site, completing a service project, collecting field data, and learning about the local land. "Changes" were described in $40 \%$ of portfolio entries and "patterns in nature" in $20 \%$. "Scientific Knowledge Assumes an Order and Consistency in Natural Systems" accounted for 80\% of the associated keywords used, with $67 \%$ scoring two. The knowledge bases identified were 57\% "both", 33\% "science", and 8\% "TEK".

Figure 50 Salmon Camp Day 4 keywords and score for portfolio entries.
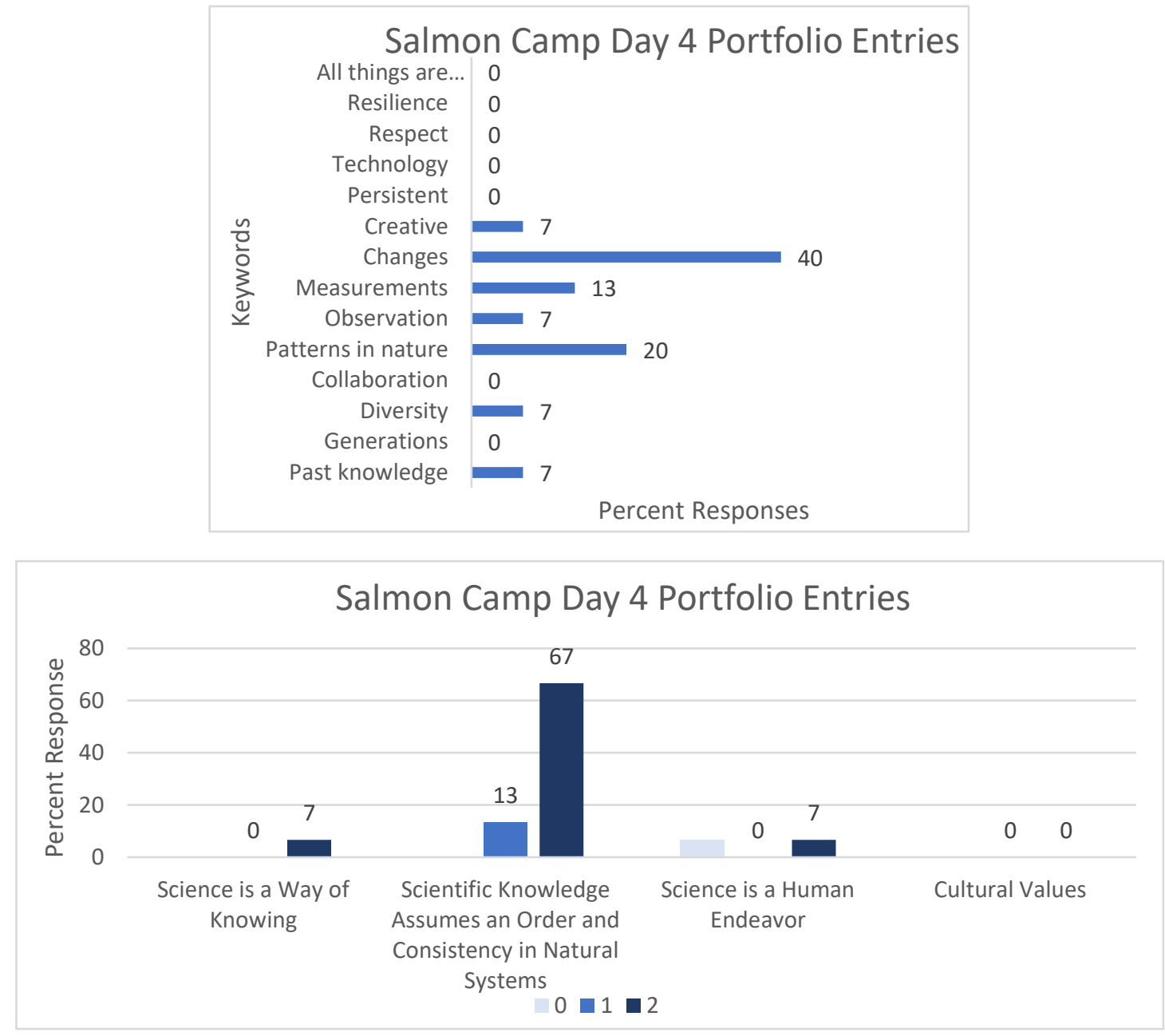


\section{Salmon Camp Day 5 Portfolio Entries}

The camp activities for this day included a college campus tour, listening to college students about their academic journey, and preparing and serving a traditional meal. "Respect", "changes" and "diversity" were the primary keywords used to describe the day's activities, each at $18 \%$. Due to the day's activities, less portfolio entries were focused on science and TEK, therefore many entries scored zero in comparison to other Salmon Camp days. "Both" knowledge bases were identified as associated to $57 \%$ of portfolio entries, and "TEK” with 52\%.

Figure 51 Salmon Camp Day 5 keywords and score for portfolio entries.
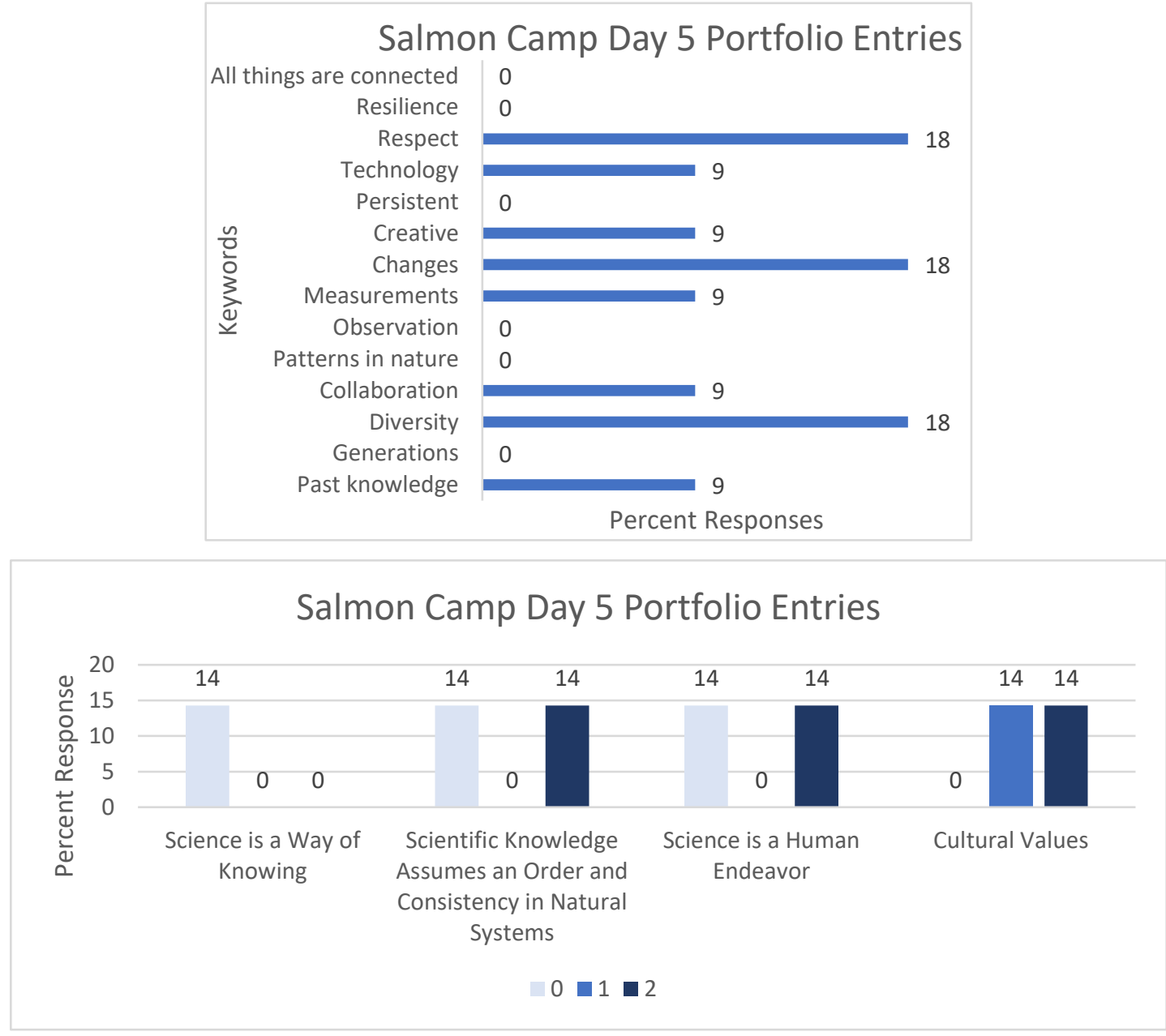


\section{Comparing PACE and Salmon Camp Instruction and Portfolio Scores}

For comparison, all portfolio entries for each camp were compiled by NOS concept. The NOS concepts are broken down by score (e.g. Of the total scores for NOS concept "Science is a Way of Knowing", 49\% scored zero for PACE). When evaluating PACE, "Science is a Way of Knowing" and "Cultural Values" exhibit greater responses scoring zero at $49 \%$ and $48 \%$, respectively. Otherwise, responses are not as differentiated. Salmon Camp shows a different trend, where all NOS concepts and cultural values have 57\% - 83\% responses scoring two. Also, only "Science is a Human Endeavor" had a larger percent of responses scoring zero and no responses scoring one. Average portfolio ratings were 1.02 (PACE) and 1.41 (Salmon Camp).

Figure 52 Result details of camp portfolio scores by NGSS NOS concept.

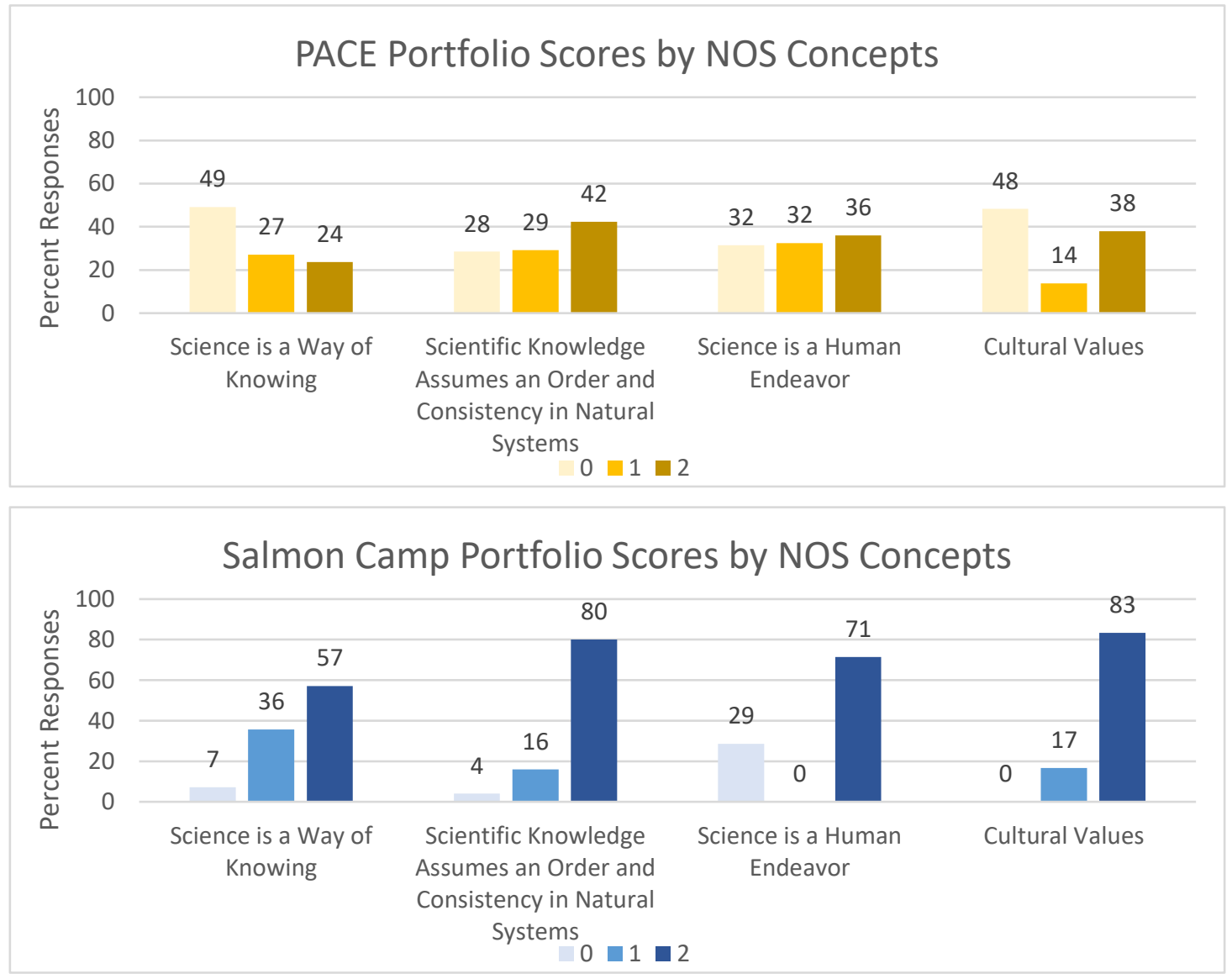




\section{Comparing Survey Scores and Portfolio Ratings}

Combining data from survey scores and portfolio ratings shows a positive correlation for both PACE and Salmon Camp. Overall, the similar slopes indicate that survey scores and portfolio scores increase at a comparable rate for each camp. The y-intercept is different for PACE and Salmon Camp by approximately 0.25, indicating Salmon Camp responses were scored and rated higher than PACE responses. It should be noted that one data point from Salmon Camp was removed, as it was an outlier in the data set (survey score increased by 22, portfolio rating was 0.67$)$.

Figure 53 Change in survey scores and portfolio ratings for PACE and Salmon Camp compared.

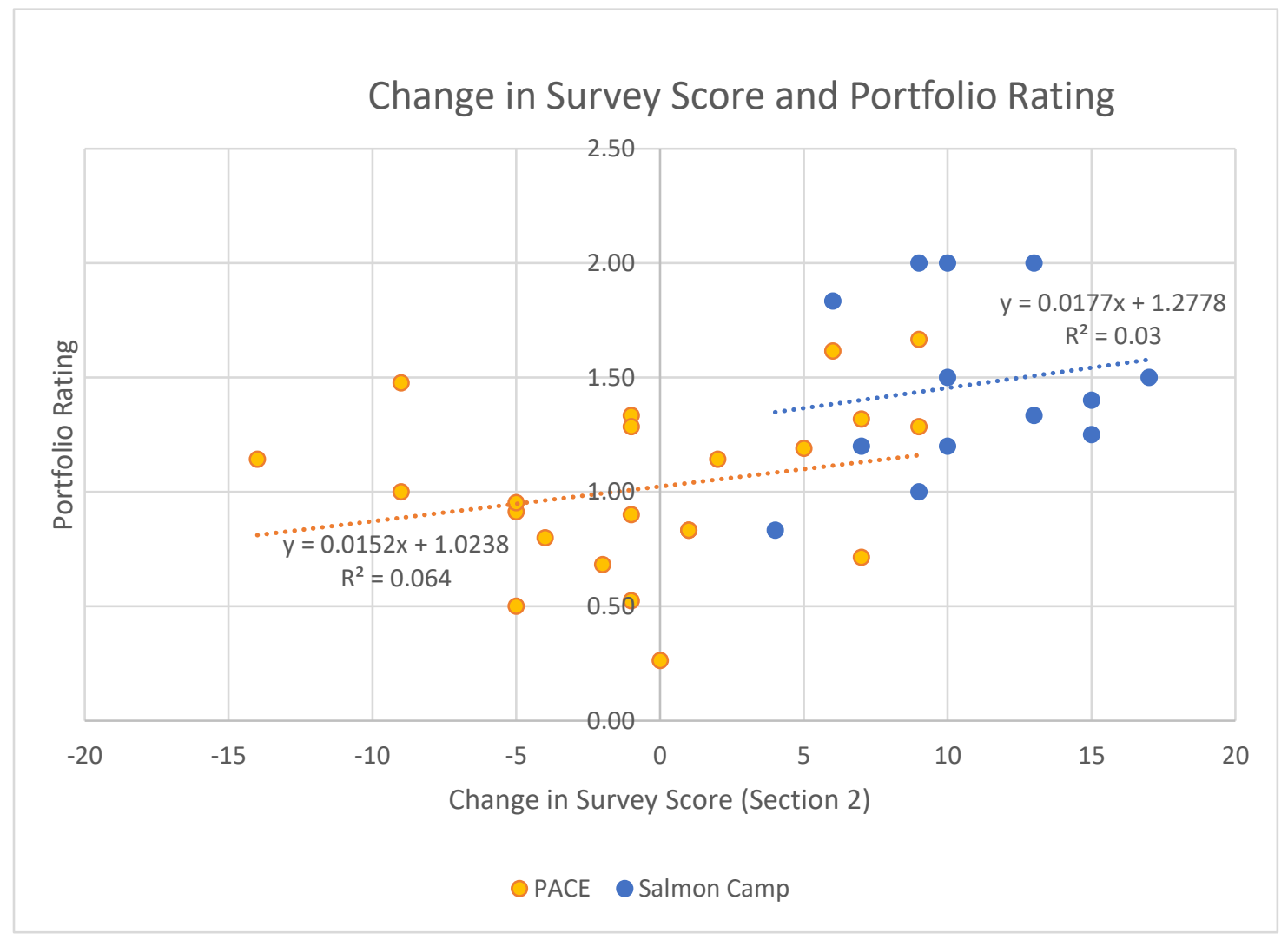




\section{Discussion}

The focus of this research is understanding the impact of incorporating traditional ecological knowledge (TEK) into summer science curriculum on middle school student's understanding of the Nature of Science. NOS instruction methods, as described by Duchl and Grandy (2013) suggest there are two versions of explicit instruction, of which TEK integration into summer science curriculum favorably demonstrates Version 2 of explicit NOS instruction. Through pre/post surveys and camp participant work samples (portfolios), the data indicates that the integration of TEK improves middle school student's understanding of some NOS concepts.

\section{Explicit NOS Instruction in Camp Activities}

The Nez Perce Tribe's PACE Math and Science Camp is developed with the objective to prepare students for high school Algebra and science, and to increase the number of students entering the STEM fields. Ten days of activities are planned, and this research focused on the science component of camps (afternoon sessions). Eleven camp activities were evaluated and averaged a score of 2.5 for Version 1 explicit NOS instruction and 4.6 for Version 2. For Version 1 teaching distinctions, PACE primarily exhibited inquiry teaching in lessons and activities that demonstrate learners' consensus 'Features' of NOS, curriculum and instruction not aligned with assessment of learning formats, and the partitioning of philosophy, psychology, and sociology, ignoring anthropology (Duschl \& Grandy, 2013). For Version 2 teaching distinctions, PACE primarily was inclusive of philosophical views from a range of science disciplines, 
focused on domain-specific disciplinary practices, demonstrated tactics and strategies of scientists, core discourse of science was central, and provided a model-based approach.

The Columbia River Inter-Tribal Fish Commission's Salmon Camp is developed with the objective to foster an interest in natural resources careers and close the achievement gap for Native American youth through culturally relevant STEM experiences. Eleven camp activities were evaluated and averaged a score of 1.1 for Version 1 explicit NOS instruction and 6.4 for Version 2. For Version 1 teaching distinction, the demonstration of tactics and strategies of scientists was less prevalent. For Version 2 teaching distinctions, Salmon Camp instruction was grounded in contemporary views that depict NOS through group activities that focus on cognitive, material, and mechanistic practices, was inclusive of philosophical views from a range of science disciplines, supported core discourse practices of science, the curriculum and instruction was aligned with assessment for learning formats, was aligned with philosophy, psychology, sociology, and anthropology, and provided history of science cases that were holistic with complex renditions.

Overall, Version 2 explicit NOS instruction was demonstrated more in Salmon Camp than in PACE. For both camps, some activities scored less than four for both Version 1 and Version 2. With NOS instruction not the focus of camp curriculum development, these observations reflect organic integration of these instruction methods.

\section{Next Generation Science Standards Nature of Science Concepts}

Four NGSS NOS were initially considered in this research: Science is a Way of Knowing, Scientific Knowledge Assumes an Order and Consistency in Natural Systems; 
Science is a Human Endeavor, and Science Addresses Questions about the Natural and Material World. The first three concepts were further analyzed in this research, as they parallel the TEK/Western Science Common Ground characteristics: Organizing Principles, Knowledge, and Habits of Mind. The NGSS NOS concepts each detail Middle School Learning Expectations which further pair with the characteristics of the TEK/Western science Common Ground concepts. With these associations, the integration of TEK into summer science camp curriculum was observed to understand the impact on students' understanding of the NGSS NOS concepts. Each NGSS NOS concept has associated learning expectations as described in the NGSS Lead States Appendix H (2013) from which the pre/post survey statements were developed. The portfolio keywords were derived from those same statements. The following sections focus on the NGSS NOS concepts and describes the data supporting the claims of the impact on TEK integration on NOS understanding.

NGSS NOS Concept: Science is a Way of Knowing

Based on the results from the survey Section 2 questions 1 through 4, a positive shift for responses to each statement was observed for Salmon camp participants, while no change was observed for PACE participants. When the data from the statements were compiled for the NGSS NOS concept "Science is a Way of Knowing”, the WilcoxonSigned Ranked Test statistical analysis indicated a significant shift in Salmon Camp responses, but not for PACE responses. PACE responses were 57\% unchanged for the NGSS NOS concept, while $76 \%$ of Salmon Camp responses improved. It should also be noted that PACE responses averaged a total score of 14 and 15 out of 20 for the pre and 
post survey for the NGSS NOS concept (indicating participants agree with the statements); while Salmon Camp averaged total scores of 9 and 11 (indicating participants were neutral in agreement/disagreement with the statements), respectively. Camp participants favored Section 3 statements associated to "Science is a Way of Knowing” as "both” Western science and TEK (66\% for PACE post survey responses and $56 \%$ for Salmon Camp post survey responses). Little change was observed in the classification of the knowledge base from the pre and post responses. In comparison to portfolio distinctions of knowledge bases, PACE participants classify "Science is a Way of Knowing” primarily as "both" TEK and Western science (55\%), and for Salmon Camp participants, the classification favors "TEK" at $71 \%$.

Portfolio scores for PACE scored 0 for 49\% $(n=59)$ of the responses associated to "Science is a Way of Knowing". Salmon Camp responses scored 2 for $57 \%(n=14)$ of responses and 36\% scored 1. For PACE, Day 7 demonstrated the highest scores for portfolio entries associated to the NGSS NOS concept, with only $8 \%(\mathrm{n}=18)$ of all entries scoring 2. There was no TEK integration on this day, and was scored at a 3 for Version 1 explicit NOS instruction and a 6 for Version 2 (recall the rating is based on a scale of $0-10$, with each point describing the number of explicit instruction characteristics exhibited as determined by Duschl and Grandy (2013). Furthermore, of the PACE portfolio entries on Day 7 associated to "Science is a Way of Knowing", 44\% $(n=9)$ classified the knowledge as "both" TEK and Western science.

For Salmon Camp Day 2 and Day 3 portfolio entries scored highest for the NGSS NOS concept, at 21\% $(\mathrm{n}=13)$ and $25 \%(\mathrm{n}=16)$ scoring 2 , respectively. Day 2 scored 
0.75 for Version 1 and 8 for Version 2, and Day 3 scored 1.5 for Version 1 and 5 for Version 2. "Salmon Camp portfolio entries associated to Science is a Way of Knowing" for Day 2 and Day 3 classified the knowledge as "TEK" for $75 \%(n=4)$ and $71 \%(n=7)$, respectively. TEK integration on Day 2 occurred in three of the four camp activities, and in five of the six camp activities for Day 3.

For "Science is a Way of Knowing", survey and portfolio data support the claim that TEK integration improves participants understanding of the NGSS NOS concept.

NGSS NOS Concept: Scientific Knowledge Assumes an Order and Consistency in Natural Systems

Based on the results from the survey Section 2 questions 5 through 8, three of the four statements had a positive shift in responses from Salmon Camp participants, while no change was observed for PACE participants. When the data from the statements were compiled for the NGSS NOS concept, the Wilcoxon-Signed Ranked Test statistical analysis indicated a significant shift in Salmon Camp responses, but not for PACE responses. PACE responses were 50\% $(\mathrm{n}=22)$ unchanged for the NGSS NOS concept, while $72 \%(n=14)$ of Salmon Camp responses improved. It should also be noted that PACE responses averaged a total score of 14 and 15 out of 20 for the pre and post survey for the NGSS NOS concept (indicating participants agree with the statements); while Salmon Camp averaged total scores of 10 (indicating neutral agreement/disagreement with the statements) and 13 (indicating some agreement with the statements), respectively. Interestingly though, camp participants favored Section 3 statements associated to "Scientific Knowledge Assumes an Order and Consistency in Natural 
Systems" as both Western science and TEK (42\% for PACE post survey responses and $57 \%$ for Salmon Camp post survey responses). Little change was observed in the classification of the knowledge base from the pre and post responses for PACE (6\% increase), while Salmon Camp increased by $17 \%$ in classification of "both" knowledge bases for the NGSS NOS concept. The Salmon Camp shift primarily came out of pre survey responses favoring "science" at 43\% initially. Portfolio entries for PACE participants classify "Scientific Knowledge Assumes an Order and Consistency in Natural Systems" primarily as "science" $(47 \%)$ and "both" $(39 \%)(n=343)$, while Salmon Camp participants classify it as "both" $(60 \%)$ and "science" $(32 \%)(\mathrm{n}=61)$.

PACE portfolio responses for "Scientific Knowledge Assumes an Order and Consistency in Natural Systems" scored 2 for $42 \%(n=144)$ of the responses associated to the NGSS NOS concept. Salmon Camp responses scored 2 for $80 \%(n=25)$ of responses. For PACE, Day 4 and Day 6 demonstrated the highest scores for portfolio entries associated to the NGSS NOS concept, with $39 \%(n=56)$ and $30 \%(n=47)$ scoring 2, respectively. There was TEK integration on both of these days. Day 4 scored a 2 for Version 1 explicit NOS instruction and a 3 for Version 2, while Day 6 average scores were 3 and 4 for Version 1 and Version 2, respectively. Furthermore, PACE portfolio entries on Day 4 and Day 6 classified the knowledge as "science" for $23 \%$ and $26 \%$ and "both" for $20 \%$ and $21 \%$, respectively.

For Salmon Camp Day 2 and Day 4 scored highest for the NGSS NOS concept, at $50 \%(\mathrm{n}=18)$ and $67 \%(\mathrm{n}=15)$ scoring 2 , respectively. Day 2 scored 0.75 for Version 1 and 8 for Version 2, and Day 4 scored 0 for Version 1 and 8 for Version 2. Salmon 
Camp portfolio entries for Day 2 classified the knowledge as "TEK" for $23 \%(\mathrm{n}=13)$, while Day 4 classification favored "both" at $46 \%(n=13)$. TEK integration on Day 2 occurred in three of the four camp activities, and was the primary focus on Day 4 (one camp activity).

For "Scientific Knowledge Assumes an Order and Consistency in Natural Systems", survey and portfolio data support the claim that TEK integration improves participants understanding of the NGSS NOS concept.

NGSS NOS Concept: Science is a Human Endeavor

Based on the results from the survey Section 2 questions 9 through 13, one of the five statements ("anyone can be a scientist") had a positive shift in responses from Salmon Camp participants, while no change was observed for PACE participants. When the data from the statements were compiled for the NGSS NOS concept, the WilcoxonSigned Ranked Test statistical analysis indicated no significant shift in Salmon Camp or PACE responses. PACE responses were 54\% unchanged for the NGSS NOS concept, while Salmon Camp responses were evenly distributed (approximately one-third with a decrease, neutral, and increased score). It should also be noted that PACE responses averaged a total score of 20 out of 25 for both the pre and post survey for the NGSS NOS concept (indicating agreement with the statements); while Salmon Camp averaged total scores of 17 and 19 (indicating some agreement with the statements), respectively. Interestingly though, camp participants favored Section 3 statements associated to "Science is a Human Endeavor" as both Western science and TEK (47\% for PACE post survey responses and $43 \%$ for Salmon Camp post survey responses). Little change was 
observed in the classification of the knowledge base as "both" from the pre and post responses for PACE (6\% decrease) and Salmon Camp (3\% increase). Portfolio responses for PACE participants classify "Science is a Human Endeavor" primarily as "both" TEK and Western science $(47 \%(\mathrm{n}=343))$, while Salmon Camp participants classify it as "both" (43\%) and "science" (31\%) $(\mathrm{n}=61)$.

Portfolio scores for Section 2 survey data shows PACE portfolio responses for "Science is a Human Endeavor" scoring 2 for $36 \%$ of the responses associated to the NGSS NOS concept, and 32\% scoring 0 and 1 each $(n=111)$. Salmon Camp responses challenge the Section 2 survey data, with $71 \%$ of portfolio responses scoring 2 and $29 \%$ scoring $0(n=7)$. For PACE, Day 7 demonstrated the highest scores for portfolio entries associated to the NGSS NOS concept, with $27 \%(n=49)$ scoring 2 . There was no TEK integration on this day, although camp activities and teaching methods scored a 3 for Version 1 explicit NOS instruction and a 6 for Version 2. Furthermore, PACE portfolio entries on Day 7 classified the knowledge as "both" for $44 \%$ of responses and $36 \%$ as "science".

For Salmon Camp Day 3 and Day 5 scored highest for the NGSS NOS concept, at $13 \%(\mathrm{n}=16)$ and $14 \%(\mathrm{n}=7)$ scoring 2 , respectively. Day 5 was disregarded for further analysis, because no TEK or science instruction occurred. Day 3 scored 1.5 for Version 1 and 5 for Version 2. Salmon Camp portfolio entries for Day 3 classified the knowledge as "science" and "both" for only $6 \%$ of responses. TEK integration on Day 3 occurred in five of the six camp activities. 
For "Science is a Human Endeavor", survey and portfolio data do not provide evidence that support the claim that TEK integration improves participants understanding of the NGSS NOS concept.

NGSS NOS Concept: Science Addresses Questions About the Natural and Material World

Based on the results from the survey Section 2 questions 14 through 16, none of the three statements observed a change for PACE and Salmon Camp participants. When the data from the statements were compiled for the NGSS NOS concept, the WilcoxonSigned Ranked Test statistical analysis indicated no significant shift in responses for either camp. PACE responses were 33\% unchanged for the NGSS NOS concept with an even distribution among decrease and increased scores. Salmon Camp responses were also evenly distributed (approximately one-third with a decrease, neutral, and increased score). It should also be noted that PACE responses averaged a total score of 14 and 15 out of 15 for both the pre and post survey for the NGSS NOS concept; while Salmon Camp averaged total scores of 10 for both pre and post survey responses. For Section 3, statements were not developed for "Science Addresses Questions About the Natural and Material World", because there was no clear association to the TEK/Science Common Ground. Likewise, keywords for portfolios were not developed for this NGSS NOS concept. Although some camp activities and teaching methods demonstrated this NGSS NOS concept, camps were not evaluated for its inclusion. 
Cultural Values

Although Cultural Values are not an NGSS NOS concept, with the integration of TEK, some evaluation occurred in portfolio analysis. No statements in survey Section 2 were related to Cultural Values, although Section 3 did have one statement directed at Cultural Values ("values like harmony, respect, resiliency, interdependence, and reciprocity are important"). The responses were included in the "Science is a Human Endeavor" analysis, because these qualities are also reflected in the NGSS NOS concept. Separate analysis for Cultural Values primarily occurred in evaluation of portfolios. Only $8 \%(n=343)$ of portfolio entries relate to Cultural Values for PACE, while an overall 12\% $(\mathrm{n}=52)$ of Salmon Camp responses relate to Cultural Values. Compiling portfolio entries for Cultural Values in PACE responses resulted in $48 \%$ scoring 0 and $38 \%$ scoring $2(\mathrm{n}=29)$. For Salmon Camp portfolio entries, $83 \%(\mathrm{n}=6)$ of responses related to Cultural Values scored 2, with no entries scoring 0.

\section{Summary and Limitations}

The data from survey Section 2 responses indicate improvement in Salmon Camp participants understanding of the NGSS NOS concepts "Science is a Way of Knowing" and "Scientific Knowledge Assumes an Order and Consistency in Natural Patterns". PACE participants did not show improvement, although there is uncertainty of the limitations of the survey. A ceiling effect was observed in PACE participant responses, which also seemed to be approached by Salmon Camp participant post survey responses. Approximately $60 \%-70 \%$ of post survey responses indicated "agreement" with survey statements. 
While Section 2 survey statements were developed to address understanding of NGSS NOS concepts, Section 3 was developed to understand how students classify the knowledge statements. These statements were directly derived from the NGSS NOS Middle School Learning Expectations, with slight modification of statements from "science is..." to "knowledge is..." Responses for Section 2 statements demonstrated general agreement, and when asked what knowledge the statements are associated to, a similar response was observed with approximately $60 \%-70 \%$ of post survey responses indicating science as an associated body of knowledge. For "Science is a Way of Knowing," $61 \%$ of PACE responses indicated science as an associated body of knowledge (i.e. responses for "both" and "science" are combined). Salmon Camp responses exhibited $73 \%$ indicating science as an associated body of knowledge. For "Scientific Knowledge Assumes an Order and Consistency in Natural Systems," 71\% of PACE responses indicated the statements were associated to science, while $76 \%$ for Salmon Camp. For "Science is a Human Endeavor," 67\% of responses for PACE and $74 \%$ of responses for Salmon Camp indicated the statements were associated to science.

Portfolio scores are the distinguishing data collected in this research. Salmon Camp participants were better able to demonstrate their understanding of the NGSS NOS concepts in their portfolios in comparison to PACE participants. While survey instruments have been criticized in the past for inability to capture students understanding, work samples have been suggested to obtain that information. Through the approach of portfolios, Salmon Camp participants out-scored PACE participants in relating camp activities to the NGSS NOS Middle School Learning Expectations 
(through keyword association). When compared, 30\% more of Salmon Camp portfolio entries scored 2 than PACE portfolio entries. Salmon Camp portfolio entries described scientific facts, drawings and descriptions of experiences from the day, and emphasized traditional ecological knowledge instruction. PACE portfolios often read "today we (listed activity)," and then provided scientific facts that were learned. Each camp had some portfolio entries that incorrectly used the keywords provided for this research, although they provided in-depth understanding of the science or TEK knowledge presented. When comparing the change in survey scores and portfolio ratings, there is a positive correlation for both camps, although Salmon Camp demonstrates a higher rated portfolio response, suggesting that Salmon Camp improves students' understanding of NGSS NOS concepts when compared to PACE.

It should be emphasized that this research is only an evaluation of explicit NOS instruction, the integration of TEK, and middle school students understanding of the NGSS NOS concepts as described. This research does not evaluate the camp as a whole, the objectives of each camp, or success of camps in attaining their individual goals. 


\section{References}

[NSTA] National Science Teachers Association (2000). The Nature of Science-A Position Statement of NSTA. Washington, DC.

[UNEP] United Nations Environment Programme. 1998. Report of the fourth meeting of the parties to the convention on biodiversity. Nairobi (Kenya): United Nations Environment Programme. UNEP/CBD/COP/4/27.

Abell, S., M. Martini, and M. George. 2001. "That's what scientists have to do": Preservice elementary teachers' conceptions of the nature of science during a moon investigation. International Journal of Science Education 23(11):10951109.

Aikenhead, G., \& Ogawa, S. (2007). Indigenous knowledge and science revisited. Cultural Studies of Science Education, 2(3), 539-620.

Akerson, V.L., F. Abd-El-Khalick, and N.G. Lederman. 2000. Influence of a reflective activity-based approach on elementary teachers' conceptions of nature of science. Journal of Research in Science Teaching 37(4):295-317.

Bell, R., Lederman, N., \& Abd-El-Khalick, F. (1998). Implicit versus explicit nature of science instruction: An explicit response to Palmquist and Finley. Journal of Research in Science Teaching, 35, 1057-1061.

Berkes, F. 1993. Traditional ecological knowledge in perspective. In J. T. Inglis (ed.), Traditional Ecological Knowledge: Concepts and Cases. (pp. 1-9) Ottawa: International Program on Traditional Ecological Knowledge and International Development Research Centre.

Branch, Glenn (2013). Evolution and climate change in the NGSS. National Center for Science Education. Retrieved August 13, 2016.

Brophy, S., Klein, S., Portsmore, M., \& Rogers, C. (2008). Advancing engineering education in P-12 classrooms. Journal of Engineering Education, 97 (3), 369-387.

Clayoquot Sound Scientific Panel (1995). First Nations Perspectives Relating to Forest Practices Standards in Clayoquot Sound Report 3.

Clough, Michael P. (2012). Effectively Teaching and Assessing the Nature of Science. NSTA National Conference, Indianapolis, IN, March 29-April 1. A version of this manuscript appears in The Science Teacher. 78(6), 56-60.

Columbia River Inter-Tribal Fish Commission [CRITFC] (2017). CRITFC Member Tribes Overview. CRITFC.org. Retrieved 18 May 2017.

Conant, J. (1947). On understanding science: An historical approach (Terry lectures). New Haven : London: Yale University Press; G. Cumberlege, Oxford University Press. 
Dagher, Z. R., \& Erduran, S. (2016). Reconceptualising the nature of science: why does it matter? Science \& Education, 25(1), 147-164.

Dana, R. (1984). Intelligence testing of American Indian children: Sidesteps in quest of ethical practice. White Cloud Journal, 3(3), 35-43.

Deloria V. 1995. Red Earth,White Lies.New York: Harper and Row.

Deng, Feng, Chen, Der-Thanq, Tsai, Chin-Chung, \& Chai, Ching Sing. (2011). Students' Views of the Nature of Science: A Critical Review of Research. Science Education, 95(6), 961-999.

DeSilver, D. (2017). U.S. students' academic achievement still lags that of their peers in many other countries. Pew Research Center. Retrieved 26 February 2017, from http://www.pewresearch.org/fact-tank/2017/02/15/u-s-students-internationallymath-science/\#

Doubleday, N. C. (1993). Finding common ground: natural law and collective wisdom. Traditional ecological knowledge: Concepts and cases, 41-53.

Duschl, R. A., \& Grandy, R. (2013). Two views about explicitly teaching nature of science. Science \& Education, 22(9), 2109-2139.

Frenkel, E. and Wu, H. (2013). "Republicans Should Love 'Common Core',' Wall Street Journal, May 6, 2013, http://online.wsj.com/article/SB1000142412788732448250457845350215593497 8.html.

Estrin, Elise Trumbull, \& Nelson-Barber, Sharon. (1995). Issues in Cross-Cultural Assessment: American Indian and Alaska Native Students. Knowledge Brief, Number Twelve. 1995.

Gay, G. (2010c). Culturally responsive teaching: Theory, research, and practice (2nd ed.). New York: Teachers College Press.

Hamlin, M. (2013). "Yo soy indígena": Identifying and using traditional ecological knowledge (TEK) to make the teaching of science culturally responsive for Maya girls. Cultural Studies of Science Education, 8(4), 759-776.

Kang, S., L. Scharmann, and T. Noh. 2004. Examining students' views on the nature of science: Results from Korean 6th, 8th, and 10th graders. Science Education 89(2):314-334.

Khishfe, R., \& Abd-El-Khalick, F. (2002). Influence of explicit and reflective versus implicit inquiry-oriented instruction on sixth graders' views of nature of science. Journal of Research in Science Teaching, 39(7), 551-578.

Khishfe, R., and F. Abd-El-Khalick. 2002. Influence of explicit and reflective versus implicit inquiry-oriented instruction on sixth graders' views of nature of science. Journal of Research in Science Teaching39(7):551-578. 
Kim, E., \& Dionne, L. (2014). Traditional Ecological Knowledge in Science Education and Its Integration in Grades 7 and 8 Canadian Science Curriculum Documents. Canadian Journal of Science, Mathematics and Technology Education, 14(4), 00.

Lederman, N., Adb-El-Khalick, F., Bell, R. L., \& Schwartz, R. S. (2002). Views of Nature of Science Questionnaire: Towards valid and meaningful assessment of learne

Lederman, N.G. (2007). Nature of science: Past, present, and future. In S.K. Abell \& N.G. Lederman (Eds.), Handbook of Research on Science Education (pp. 831879). Mahwah, NJ: Erlbaum.

Lederman, N.G., and J.S. Lederman. 2004. Revising instruction to teach nature of science. The Science Teacher 71(9):36-39.

Ledoux, J. (2006). INTEGRATING ABORIGINAL PERSPECTIVES INTO CURRICULA: A LITERATURE REVIEW. The Canadian Journal of Native Studies, 26(2), 265-288.

Lipka, J., \& Adams, B. (2004). Culturally Based Math Education as a Way to Improve Alaska Native Students' Math Performance. Appalachian Collaborative Center for Learning.

MacDonald, D. (1996 August). Making both the nature of science and science subject matter explicit intents of science teaching. Journal of Science Teacher Education. 7(3) 183-96.

Mccarter, J., \& Gavin, M. (2011). Perceptions of the value of traditional ecological knowledge to formal school curricula: Opportunities and challenges from Malekula Island, Vanuatu. Journal of Ethnobiology and Ethnomedicine, 7, 38.

McComas, W. F., \& Olson, J. K. (1998). The nature of science in international science education standards documents. In W. F. McComas (Ed.), The nature of science in science education: Rationales and strategies (pp. 41-52). Dordrecht: Kluwer.

Montenegro, E., \& Jankowski, N. A. (2017). Equity and Assessment: Moving towards Culturally Responsive Assessment. Occasional Paper\# 29. National Institute for Learning Outcomes Assessment.

Moss, D.M. 2001. Examining student conceptions of the nature of science. International Journal of Science Education 23(8):771-790.

Murphy, B., Ballard, Heidi, Carter Ching, Cynthia, \& Passmore, Cynthia. (2010). Culture Camp: Examining Teaching and Learning at the Convergence of Traditional Knowledge and Western Science, ProQuest Dissertations and Theses.

National Research Council (2012). A Framework for K-12 Science Education: Practices, Crosscutting Concepts, and Core Ideas. Washington, DC: National Academies Press. 
NCAI Policy Research Center and MSU Center for Native Health Partnerships. (2012). 'Walk softly and listen carefully': Building research relationships with tribal communities. Washington, DC, and Bozeman, MT: Authors.

NGSS Lead States. (2013). Next generation science standards: For states, by states. Washington, DC: The National Academies Press.

Palmquist, Bruce C., \& Finley, Fred N. (1997). Preservice Teachers' Views of the Nature of Science during a Postbaccalaureate Science Teaching Program. Journal of Research in Science Teaching, 34(6), 595-615.

Reid, A., Teamey, K., \& Dillon, J. (2004). Valuing and utilizing traditional ecological knowledge: Tensions in the context of education and the environment. Environmental Education Research, 10(2), 237-254.

Roehrig, G., Campbell, K., Dalbotten, D., \& Varma, K. (2012). CYCLES: A culturallyrelevant approach to climate change education in native communities. Journal of Curriculum and Instruction, 6(1), 73-89.

Rosicka, Christine, "Translating STEM education research into practice" (2016). https://research.acer.edu.au/professional_dev/10

Ruddle, K. (1993). The transmission of traditional ecological knowledge. Traditional ecological knowledge: Concepts and cases. Ottawa, Canadian Museum of Nature and IDRC, 17-31.

Ruddle, K. and Chesterfield, R. (1977). Education for Traditional Food Procurement in the Orinoco Delta. Ibero-Americana 53. Berkeley and Los Angeles, University of California Press.

Slater, Timothy F. (2017). Classroom Assessment Techniques Portfolios. Field-tested Learning Assessment Guide. Retrieved 26 April 2016, from http://archive.wceruw.org/cl1/flag/cat/portfolios/portfolios7.htm

Snively, G. (1995). Bridging traditional science and western science in the multicultural classroom. In G. Snively \& A. MacKinnon (Eds.), Thinking globally about mathematics and science education (pp. 53- 75). Vancouver: University of British Columbia, Research and Development Group.

Snively, G., \& Corsiglia, J. (2001). Discovering indigenous science: Implications for science education. Science Education, 85(1), 6-34.

Stangroom, J. 2017. Wilcoxon signed-rank test calculator. Available online at http://www.socscistatistic.com/tests/signedranks. Accessed 10 May 2017. Google Scholar

Stephens, S., Educational Resources Information Center, \& Alaska Univ., Fairbanks. Alaska Native Knowledge Network. (2001). Handbook for Culturally Responsive Science Curriculum. S.1.]: Distributed by ERIC Clearinghouse. 
Stevenson, M. G. (1996). "Indigenous Knowledge in Environmental Assessments." Arctic 49(3): 278-291.

Turner, N. J., Ignace, M. B., \& Ignace, R. (2000). Traditional ecological knowledge and wisdom of aboriginal peoples in British Columbia. Ecological applications, 10(5), 1275-1287.

US Census (2000). Census 2000 Summary File 1. Retrieved from factfinder2.census.gov

US Environmental Protection Agency (2011). Integration of traditional ecological knowledge (TEK) in environmental science, policy, and decision-making. In the National EPA - Tribal Science Council (ed.) Tribal Science Priority - Final.

US Fish and Wildlife Service (2011). Traditional ecological knowledge for application by service scientists. Washington D.C. Retrieved 17 March 2016, from https://www.fws.gov/nativeamerican/pdf/tek-fact-sheet.pdf

US National Park Service (2015). The Treaty Period- Nez Perce National Historical Park. US Department of Interior (NPS.org). Retrieved 23 March 2017 from https://www.nps.gov/nepe/learn/historyculture/the-treaty-era.htm

Yoon, S. A., Koehler-Yom, J., Anderson, E., Oztok, M., Klopfer, E., Schoenfeld, I., ... Scheintaub, H. (2015). Impacts on student understanding of scientific practices and crosscutting themes through an NGSS-designed computer-supported curriculum and instruction project. In O. Lindwall, P. Häkkinen, T. Koschmann, P. Tchounikine, \& S. Ludvigsen (Eds.), Exploring the Material Conditions of Learning: The Computer Supported Collaborative Learning (CSCL) Conference 2015. (Vol. 1, pp. 142-149). International Society of the Learning Sciences.

Zent, S. (2008). Methodology for developing a vitality index of traditional environmental knowledge (VITEK). Technical report to the Christensen fund. Salt Spring Island, British Columbia: Terralingua. 
Appendix A: NGSS Nature of Science Concepts

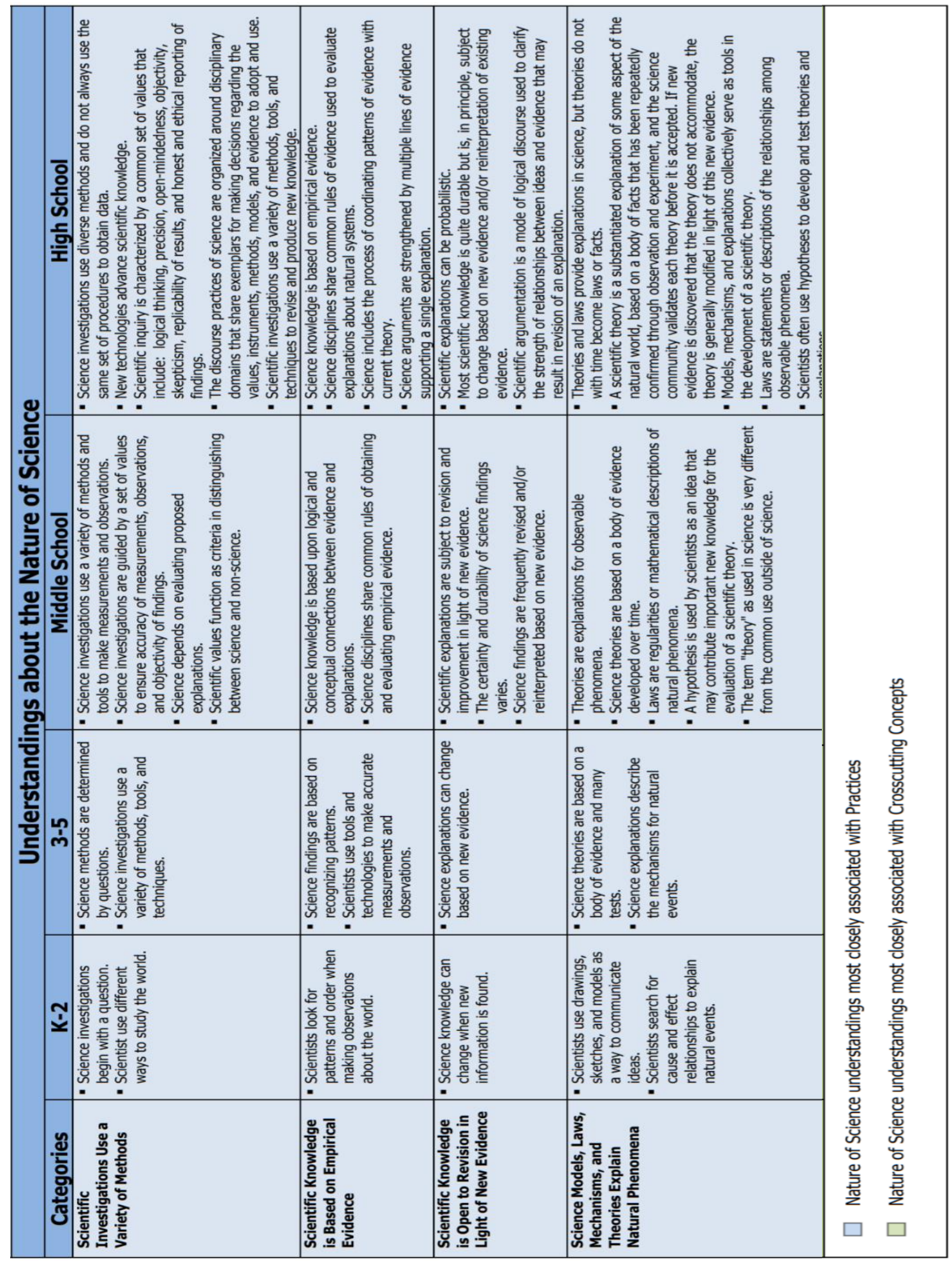




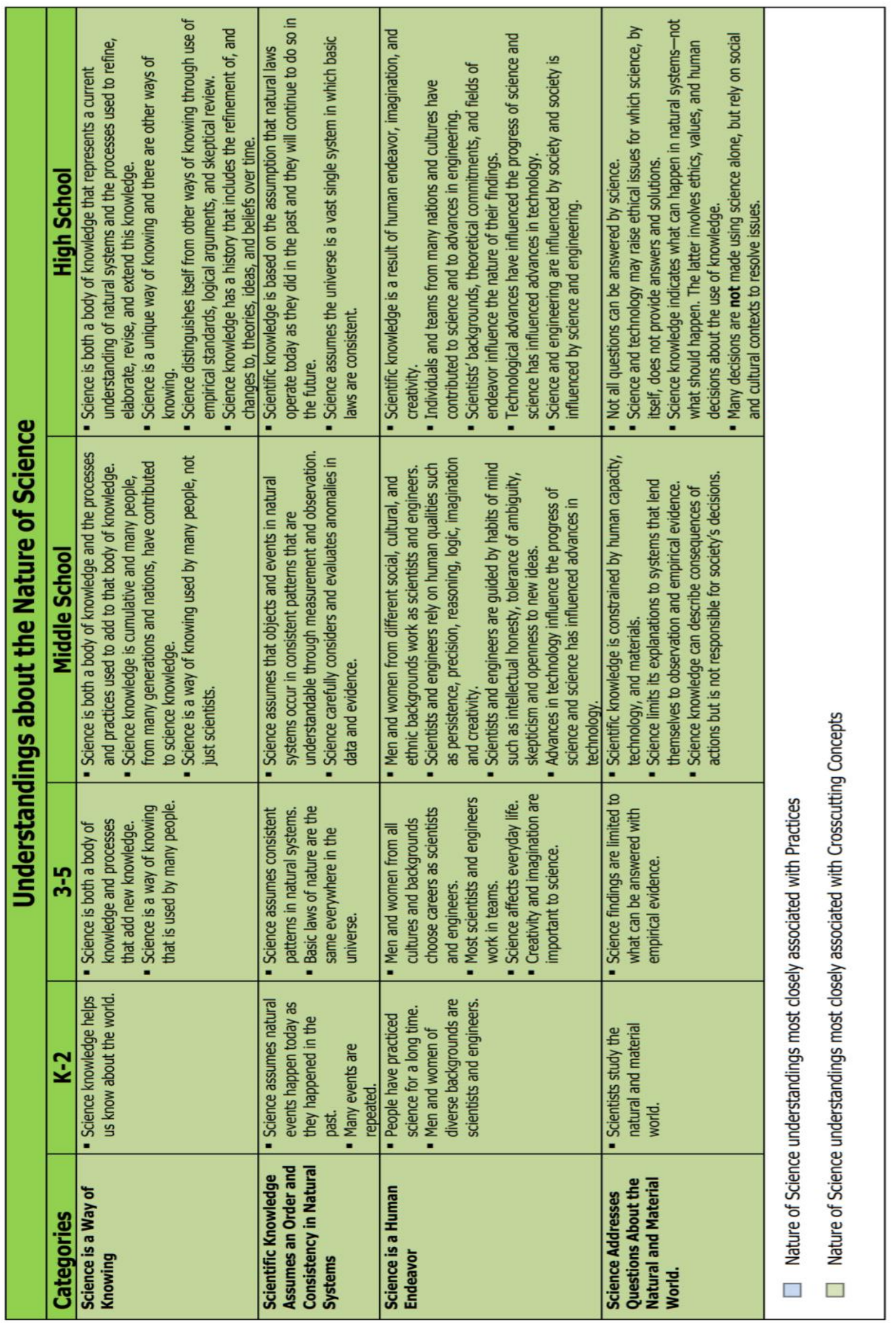


Appendix B: PACE Daily Worksheet (student work sample template)

Initials:

Birthday:

Male Female

Describe three things you learned today using pictures, words, symbols, etc.

Include keyword(s) in your description.

Select the knowledge your keyword describes (TEK, Science, Both, or Neither)

\begin{tabular}{|c|c|c|c|c|c|}
\hline & & & & $\begin{array}{l}>\mathrm{I} \\
>\mathrm{C} \\
>\mathrm{C} \\
>\mathrm{P} \\
>\mathrm{C} \\
>\mathrm{N} \\
>\mathrm{C} \\
>\mathrm{C} \\
\mathrm{p} \\
>\mathrm{C} \\
>\mathrm{P} \\
>\mathrm{R} \\
>\mathrm{R} \\
>\mathrm{A} \\
\mathrm{C} \\
>\mathrm{T}\end{array}$ & $\begin{array}{l}\text { Keywords } \\
\text { owledge } \\
\text { ions } \\
\text { ration } \\
\text { in nature } \\
\text { itions } \\
\text { ements } \\
\text { y (all kinds of } \\
\text { nce } \\
\text { gs are } \\
\text { ed } \\
\text { ogy } \\
\text { cy }\end{array}$ \\
\hline Day & Keyword(s) & TEK & Science & Both & Neither \\
\hline
\end{tabular}


Appendix C: Research Permit for the Nez Perce Tribe

\section{RESEARCH PERMIT SIGN-OFF SHEET}

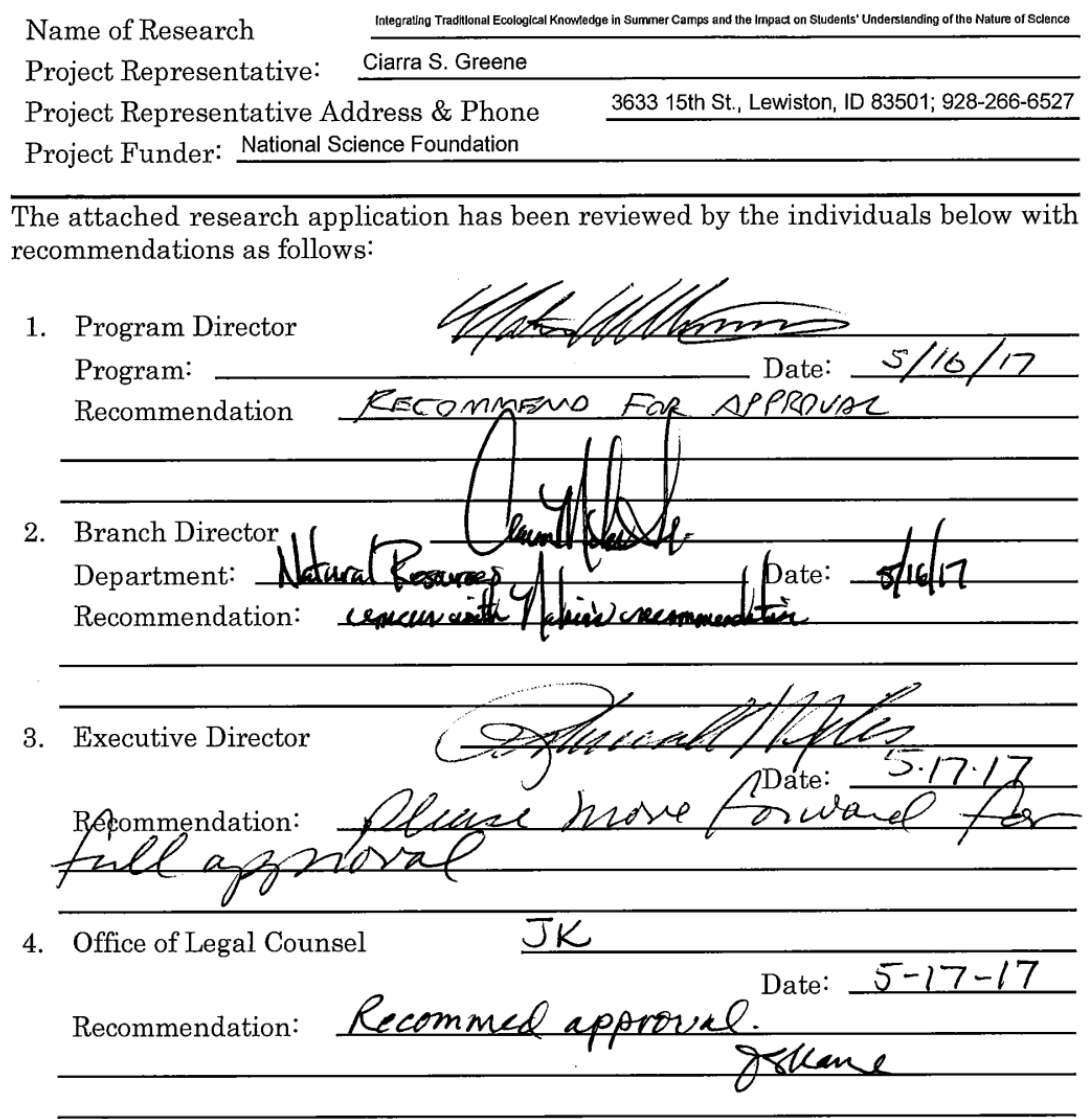

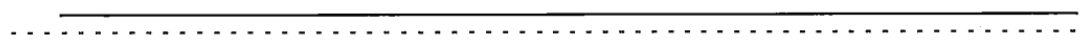

-

NPTEC presentation by: (Department Manager or Executive Director):

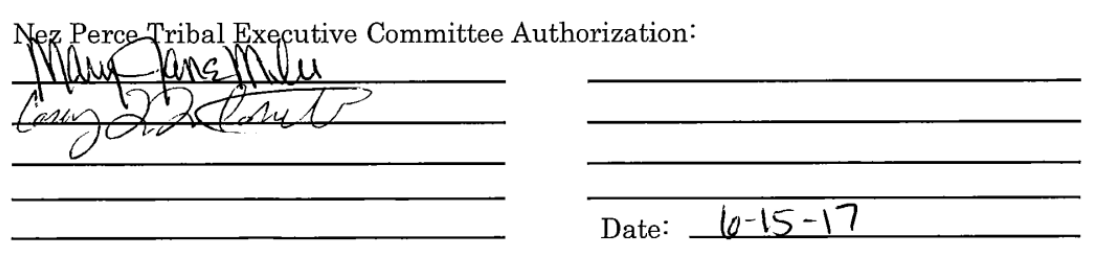




\section{Appendix D: IRB Approval from Portland State University}

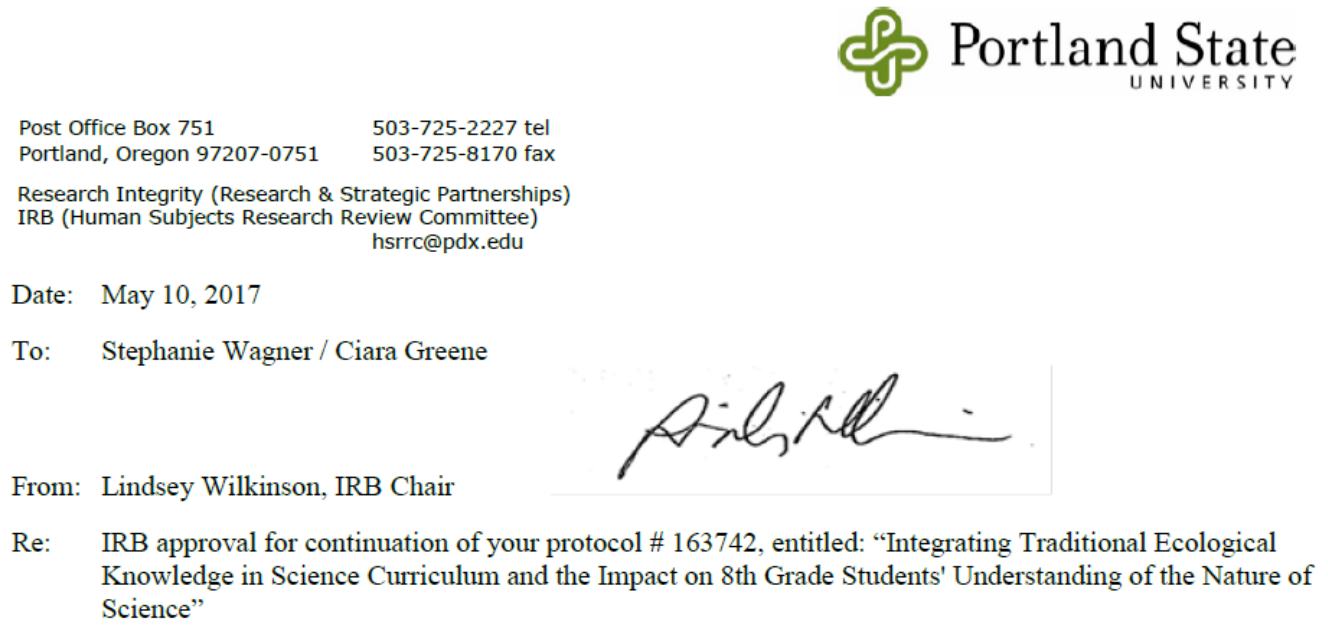

Approval-Expiration: May 10, 2017 - May 11, 2018

\section{Notice of IRB Review and Approval - Continuing Review Expedited Review Categories 5, 6, 7; as per Title 45 CFR Part 46}

The continuation report for the project identified above has been reviewed and approved by the PSU IRB (Human Subjects Research Review Committee) and the Research Integrity office using an expedited review procedure. This is a minimal risk study. The IRB is satisfied that your provisions for protecting the rights and welfare of all subjects participating in the research are adequate. Please note the following requirements:

Approval: You are approved to conduct this research study only during the period of approval cited above, and the research must be conducted according to the plans and protocol submitted (approved copy enclosed).

Consent: You must use IRB-approved consent materials with study participants. PLEASE NOTE: The consents/assents attached to the continuation report do not match the approved materials. If changes have been made, please submit the changed documents with an Amendment Request Form (found on the ORI Human Subjects website). Until such are received and approved, you are required to use the consent forms that have been approved (in the initial submission).

Changes to Protocol: Any changes in the proposed study, whether to procedures, survey instruments, consent forms or cover letters, must be outlined and submitted to the IRB immediately. The proposed changes cannot be implemented before they have been reviewed and approved by the IRB.

Continuing Review: This approval will expire on 05/11/2017. It is the investigator's responsibility to ensure a Continuing Review Report is submitted to the IRB two months before the expiration date, and that approval of the study is kept current. The Continuing Review Report is available on the Research Integrity website.

Adverse Reactions and/or Unanticipated Problems: If any adverse reactions or unanticipated problems occur as a result of this study, you are required to notify the Research Integrity office within 5 days of the event. If the issue is serious, approval may be withdrawn pending an investigation by the IRB.

Completion of Study: Please notify the IRB as soon as your research has been completed. Study records, including protocols and signed consent forms for each participant, must be kept by the investigator in a secure location for three years following completion of the study (or per any requirements specified by the project's funding agency).

If you have questions or concerns, please contact the Research Integrity office in Research \& Strategic Partnerships at hsrrc@pdx.edu or (503) 725-2227. 
Appendix E: Research agreement with CRITFC

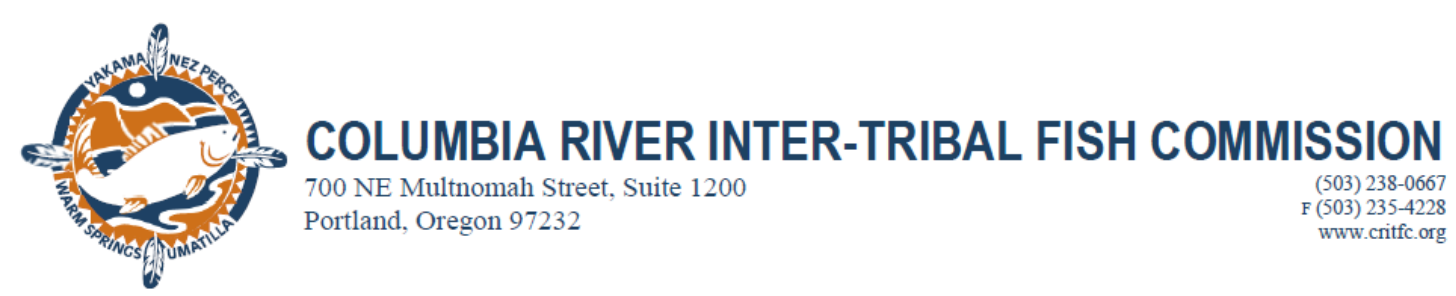

May 26, 2017

Portland State University

Center for Science Education (CSE)

P.O. Box 751

Portland State University

Portland, OR 97201

To Whom It May Concern:

On behalf of the four tribes (Warm Springs, Umatilla, Nez Perce and Yakama) of the Columbia River Inter-Tribal Fish Commission (CRITFC), I am writing to express support for and commitment to Ciarra Greene's proposed master's thesis research project Integrating Traditional Ecological Knowledge in Science Curriculum and the Impact on Student's Understanding of the Nature of Science. CRITFC is excited to participate in this research that supports the educational empowerment of American Indian/Alaska Native students through the incorporation of culturally relevant curriculum.

One of the components of Ms. Greene's proposed project is to evaluate the effectiveness of the use of Traditional Ecological Knowledge (TEK) in CRITFC's annual Salmon Camp. This is a week-long camp providing tribal middle school students with culturally relevant science, technology, engineering, and mathematics (STEM) experiences to foster an interest in natural resources careers and close the achievement gap for Native American youth.

This research will be tailored to meet the needs of the students in a culturally responsive manner. CRITFC will recruit tribal youth for Salmon Camp, provide materials and supplies, as well as review evaluation materials as they are developed.

CRITFC appreciates the opportunity to be involved in this significant research brought forward by Ciarra Greene.

If you have any questions, please feel free to contact Tana Atchley, Tribal Workforce Development and Outreach Coordinator, or myself at (503) 238-0667.

Sincerely,

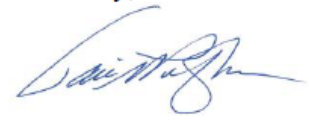

Jaime Pinkham

Executive Director 
Appendix F: Schedule for PACE Camp

\section{PACE SCHEDULE 2017}

Monday, July 17, 2017:

8:00 am

$8: 30$ am

8:30-8:45 am

8:45-9:30 am

9:30-10:30 am

10:30-11:30 am

$11: 30$ am-12:30 pm

12:30-1:00 pm

$1: 00-1: 30 \mathrm{pm}$

1:30-2:00 pm

2:00-2:15 pm

2:15-3:00 pm

3:00-3:30 pm

$3: 30$

3:40 pm

4:00 pm
Van Departs LCSC Activity Center

Students Arrive Lapwai High School

Continental Breakfast

Introductions, Review Conduct Code, Expectations, etc.

Pre-test

Teams and Groups

Lunch (Lapwai Elementary)

Physical Activity

"Closing the Circle" Video

"The NiMiiPuu" Video

Break

Cultural Identity

Traditional Ecological Knowledge

Schedule Review/Wrap-up

Van Departs for LCSC

Van Arrives LCSC Activity Center

Van Departs LCSC Activity Center

Students Arrive Lapwai High School

Continental Breakfast

Math/Science Modules

Break/Transition

Math/Science Modules

Lunch (Lapwai Elementary)

Depart for U of I.

UI- Computer Science Dept.

Transition/Return to Vans

Vans Depart for LCSC/Lapwai

Vans Arrive LCSC/Lapwai

Wednesday, July 19, 2017:

8:00 am

$8: 30$ am

8:30-8:45 am

8:45-10:00 am

10:00-10:15 am
Van Departs LCSC Activity Center

Students Arrive Lapwai High School

Continental Breakfast

Math/Science Modules

Break/Transition 
10:15-11:30 am

$11: 30 \mathrm{am}-12: 30 \mathrm{pm}$

12:30-1:00 pm

1:00-2:15 pm

2:15-2:30 pm

2:30-3:45 pm

$3: 45 \mathrm{pm}$

4:00 pm

Thursday, July 20, 2017:

8:00 am

$8: 30$ am

8:30-8:45 am

8:45-10:00 am

10:00-10:15 am

10:15-11:30 am

11:30 am-12:30 pm

$12: 30 \mathrm{pm}$

1:30-2:45 pm

$2: 45 \mathrm{pm}$

3:00 pm

4:00 pm

Friday, July 21, 2017:

8:00 am
8:30 am
8:30-8:45 am
8:45-10:00 am
10:00-10:15 am
10:15-11:30 am
11:30 am-12:30 pm
12:30 pm
$1: 00-2: 15 \mathrm{pm}$
$2: 15-2: 30 \mathrm{pm}$
$2: 30-3: 45 \mathrm{pm}$
$3: 45 \mathrm{pm}$
$4: 00 \mathrm{pm}$

Monday, July 24, 2017:

8:00 am

$8: 30$ am

8:30-8:45 am

8:45-10:00 am

10:00-10:15 am
Math/Science Modules

Lunch (Lapwai Elementary)

Class Assignments and Projects

To Be Determined

Break/Transition

To Be Determined

Van Departs for LCSC

Van Arrives LCSC Activity Center

Van Departs LCSC Activity Center

Students Arrive Lapwai High School

Continental Breakfast

Math/Science Modules

Break/Transition

Math/Science Modules

Lunch (Lapwai Elementary)

Vans Depart for Dworshak Fish Hatchery

Dworshak Fish Hatchery Tour

Return to vans

Depart for Lapwai

Arrive Lapwai High School

Van Departs LCSC Activity Center

Students Arrive Lapwai High School

Continental Breakfast

Math/Science Modules

Break/Transition

Math/Science Modules

Lunch (Lapwai Elementary)

Physical Activity

Air Quality/Students for Success

Break/Transition

Students for Success/Air Quality

Depart for LCSC

Arrive LCSC

Van Departs LCSC Activity Center

Students Arrive Lapwai High School

Continental Breakfast

Math/Science Modules

Break/Transition 
10:15-11:30 am

$11: 30-12: 30 \mathrm{pm}$

12:30-1:00 pm

$1: 00-2: 15 \mathrm{pm}$

2:15-2:30 pm

2:30-3:45 pm

$3: 45 \mathrm{pm}$

$4: 00 \mathrm{pm}$

Tuesday, July 25, 2017:

8:00 am

$8: 30$ am

8:30-8:45 am

8:45-10:00 am

10:00-10:15 am

10:15-11:30 am

$11: 30 \mathrm{am}-12: 30 \mathrm{pm}$

12:30-1:00 pm

1:00-3:45 pm

$3: 45 \mathrm{pm}$

4:00 pm

Wednesday, July 26, 2017:

8:00 am
8:30 am
8:30-8:45 am
8:45-10:00 am
10:00-10:15 am
10:15-11:30 am
11:30 am-12:30 pm
$12: 30-1: 00 \mathrm{pm}$
$1: 00-3: 45 \mathrm{pm}$
$3: 45 \mathrm{pm}$
$4: 00 \mathrm{pm}$

Thursday, July 27, 2017:

8:00 am
8:30 am
8:30-8:45 am
8:45-10:00 am
10:00-10:15 am
10:15-11:30 am
$11: 30 \mathrm{am}-12: 30 \mathrm{pm}$
$12: 30 \mathrm{pm}$

Math/Science Modules

Lunch (Lapwai Elementary)

Student Assignments/Projects

U I- College of NR: Fish \& Wildlife Sciences/NPT Cultural Break/transition

NPT Cultural/UI- College of NR: Fish \& Wildlife Sciences

Van Departs for LCSC

Van Arrives LCSC Activity Center

\author{
Van Departs LCSC Activity Center \\ Students Arrive Lapwai High School \\ Continental Breakfast \\ Math/Science Modules \\ Break/Transition \\ Math/Science Modules \\ Lunch (Lapwai Elementary) \\ Physical Activity \\ UI- Biology Division \\ Vans Return to LCSC/Lapwai \\ Vans Arrive LCSC/Lapwai
}

Van Departs LCSC Activity Center

Students Arrive Lapwai High School

Continental Breakfast

Math/Science Modules

Break/Transition

Math/Science Modules

Lunch (Lapwai Elementary)

Student Assignments/Projects

Washington State Department of Ecology

Van Departs for LCSC

Van Arrives LCSC Activity Center
Van Departs LCSC Activity Center
Students Arrive Lapwai High School
Continental Breakfast
Math/Science Modules
Break/Transition
Math/Science Modules
Lunch (Lapwai Elementary)
Bus Departs for Dworshak Marina (Swimming) 
$1: 30-2: 45 \mathrm{pm}$

3:00 pm

4:00 pm

Friday, July 28, 2017:

8:00 am

$8: 30$ am

8:30-8:45 am

$8: 45-10: 00 \mathrm{am}$

10:00-10:15 am

10:15-11:30 am

$11: 30$ am

12:00-1:00 pm

1:00-2:30 pm

$2: 30 \mathrm{pm}$
Swimming

Bus Departs for LCSC/Lapwai

Bus Arrives LCSC Activity Center/Lapwai

Van Departs LCSC Activity Center

Students Arrive Lapwai High School

Continental Breakfast

Student Assignments/Projects

Break

Post-Test

Wrap-up \& Clean-up

Lunch (Lapwai High School Commons- Families Invited)

Awards Assembly

PACE Group Picture 2017

\section{CONGRATULATIONS!}

YOU JUST COMPLETED THE $20^{\text {th }}$ ANNUAL

TWO WEEK PACE MATH \& SCIENCE CAMP 2017....WOOHOO! 
Appendix G: Schedule for Salmon Camp

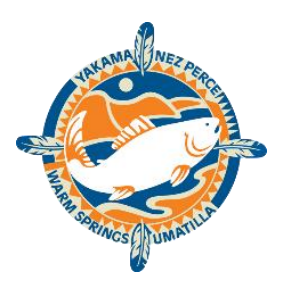

\section{Tribal Salmon Camp 2017: Program Agenda}

Sunday, June 25 - Friday, June 30, 2017

Location: Emigrant Springs State Heritage Site - Community Building near Meacham, OR

Camp Host: Confederated Tribes of the Umatilla Indian Reservation Program Lead: Tana Atchley

Sunday, June 25

12:00 Check-in

12:00 Lunch

1:30 Unpack

2:30 Icebreakers \& guidelines

4:00 Salmon Camp Overview

5:00 Dinner

6:00 Sweat

8:00 Return to Camp - Showers

9:30 Return to teepees

10:00 Lights out

Monday, June 26

6:00 Wake up

6:45 Breakfast

7:30 Depart for Walla Walla Community College

9:00 CTUIR Mussel \& Lamprey Research \& Restoration Overview

11:00 Travel to Walla Walla River Habitat Project in Milton Free Water

11:20 Lunch

2:00 Swimming

4:00 Return to Camp

6:00 Dinner

7:00 Evening Program: Wenix Red Elk - First Foods Introduction

9:30 Return to cabins

10:00 Lights out 


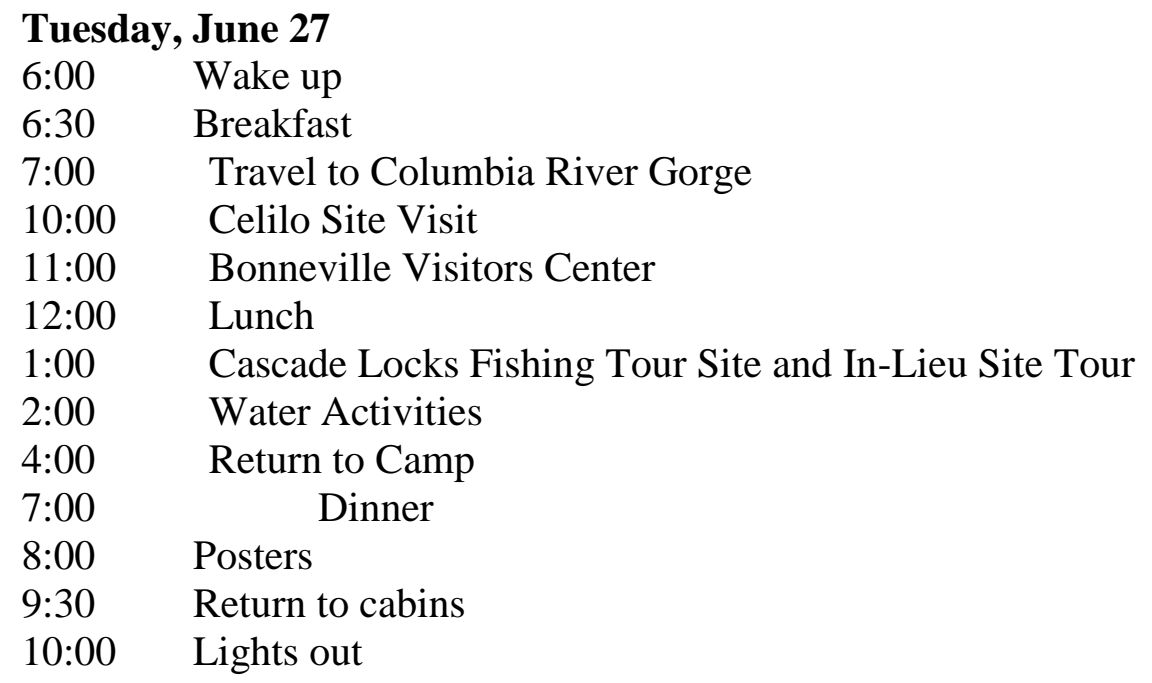

\section{Wednesday, June 28}

6:00 Wake up

6:30 Breakfast

7:30 Depart for Projects

9:00 Meacham Creek Project Site Overview

9:45 Planting Project

11:45 Lunch

12:30 Planting Project

2:00 Return to Camp

5:00 Dinner

6:00 Sweat

8:00 Return to Camp - Showers

9:30 Return to teepees

10:00 Lights out

\section{Thursday, June 29}

6:00 Wake up

7:00 Breakfast

8:00 Travel to La Grande

9:00 Eastern Oregon University Tour

11:00 Lunch

12:00 Depart for Camp

1:30 Leave for Longhouse

2:00 First Foods Overview \& Longhouse Serving

3:00 Help with Dinner Prep 
6:00 Traditional Dinner

7:30 Clean Up

8:30 Depart for Camp

9:30 Return to cabins

10:00 Lights out

\section{Friday, June 30}

6:00 Wake up

8:00 Breakfast

9:00 Camp wrap-up

12:00 Closing BBQ

1:30 Camp Pictures \& Finish Clean Up

2:00 - 3:00 Head Home 


\section{Appendix H: Camp Introduction}

Hello my name is Ciarra Greene; I am Nez Perce. How many of you fish? Hunt? Gathering berries? Roots? I grew up hunting and fishing, going sweat, and playing basketball, softball, volleyball, track, and loved hiking and mountain biking. I rode my bike everywhere! I graduated from Lewiston High School ten years ago! Since I graduated HS I have been on an adventure. I went straight to college in Flagstaff, Arizona and got my degree in chemistry from Northern Arizona University. I've worked for our tribe through internships and as a water resource specialist, and now I go to school at Portland State University. My research now is in science education. This camp is actually part of my research. Each of you get to help me collect data on the camp just by providing your thoughts through a survey that we'll take here in a minute, and create a portfolio throughout camp. (Insert personal connection to camp: i.e.For this camp especially, I will need your help on the data collection, because I never attended Salmon Camp when I was your age.)

So, let me tell you a little bit about the research and then I'll take some questions. The survey and portfolios I'll get into when we get there, but the overall theme of my research is to understand how camp impacts our thoughts on science. Throughout camp, all information is viewed as without having a right or wrong answer, there may be statements that you agree with and others you do not, and as a survey tool, it is used to see what everyone thinks. 
In my research, I am also curious if we recognize that parts of science are like our traditional ecological knowledge. What do I mean by TEK? Let's break it down together real quick: what does TRADITIONAL mean? What about ECOLOGICAL? KNOWLEDGE? Right,

so (insert their comprised explanation: i.e. knowledge about our local environmental and ecosystems that comes from our ancestors; repeat phrase three times and write on board/poster).

So my research is looking at science and traditional ecological knowledge. Providing your thoughts will help us understand your experience at camp. Any questions? I mean you can ask me anything... about my dog, my research, college, my family... I'll be here with you throughout camp so don't be shy to ask me questions or give me some tips.

\section{$\underline{\text { Pre-Survey }}$}

The pre-survey will take you as long as you need to finish it. There is no rush. On the top, the survey asks for your initials - like my name is Ciarra Greene, so my initials are CG; my birthdate 12/28/88; and gender. Section 1 of the survey asks about your engagement in activities that are related to TEK, so if you have ever hunted or gathered berries you check those, or if you've done other traditional activities there is space for you to add those. Section 2 has statements about science and you mark if you 
strongly disagree, disagree, neither, agree, strongly agree. Remember take your time reading the statements, there is no right or wrong answer, and this is just to survey what everyone thinks. The last part of the survey, Section 3, has general statements about knowledge, and you'll consider if the statement is related to TEK, science, both, or neither. If you have any questions about what something means, you can ask me, no problem. Remember take as long as you need. Unless anyone has an immediate question, go ahead and get started on those.

\section{$\underline{\text { Portfolios }}$}

This (daily worksheet/poster) will be part of your camp portfolio. You'll reflect on the day about what you experienced, what you learned, how you felt, who you met, and so on. You can use words, pictures, symbols, artwork, concept maps, and your own design to communicate your thoughts. I came up with a list of keywords I want you to try and use for each day. (Go over keywords and the related NGSS NOS understanding). So for your portfolio entry you can think about if we saw past knowledge being shared by elder or scientists? Did we meet different kinds of people and what were they doing (science, or traditional activities? Or maybe you want to describe how all the things we learned today were connected. Above all though, this is your chance you reflect, share, and analyze what you learned here at camp. (For Salmon Camp: you will get sharing these with your families and home communities). 
This is the same as the pre-survey, so after you write your initial, birthdate, and gender, you can skip Section 1. Fill out sections 2 and 3 remember that Section 2 you'll indicate if you strongly disagree to strongly agree with the statement about science. Section 3 you'll indicate if you think the statement about knowledge is related to TEK, science, both, or neither. Remember take your time reading the statements, there is no right or wrong answer, and this is just to survey what everyone thinks. If you have any questions about what something means, you can ask me, no problem. Remember take as long as you need. Unless anyone has an immediate question, go ahead and let' 